Portland State University

PDXScholar

TREC Final Reports

Transportation Research and Education Center

(TREC)

$2-2010$

Instrumentation for Mechanistic Design

Implementation

Todd Scholz

Oregon State University

Follow this and additional works at: https://pdxscholar.library.pdx.edu/trec_reports

Part of the Transportation Engineering Commons

Let us know how access to this document benefits you.

Recommended Citation

Scholz, Todd. Instrumentation for Mechanistic Design Implementation. OTREC-RR-10-02. Portland, OR:

Transportation Research and Education Center (TREC), 2010. https://doi.org/10.15760/trec.92

This Report is brought to you for free and open access. It has been accepted for inclusion in TREC Final Reports by an authorized administrator of PDXScholar. Please contact us if we can make this document more accessible: pdxscholar@pdx.edu. 


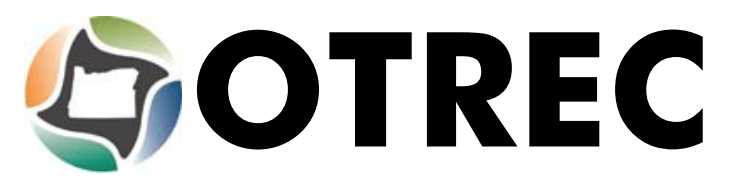

FINAL REPORT

\section{Instrumentation for Mechanistic Design Implementation}

OTREC-RR-10-02

February 2010 



\title{
INSTRUMENTATION FOR MECHANISTIC DESIGN IMPLEMENTATION
}

\author{
Final Report \\ OTREC-RR-10-02 \\ by \\ Todd V. Scholz, Ph.D., P.E. \\ Oregon State University \\ for \\ Oregon Transportation Research \\ and Education Consortium (OTREC) \\ P.O. Box 751 \\ Portland, OR 97207

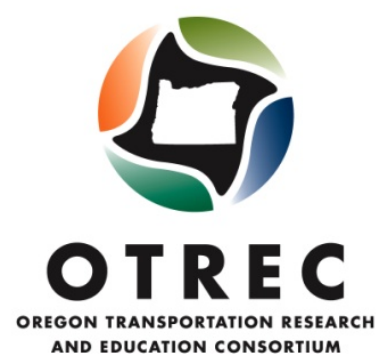

February 2010 



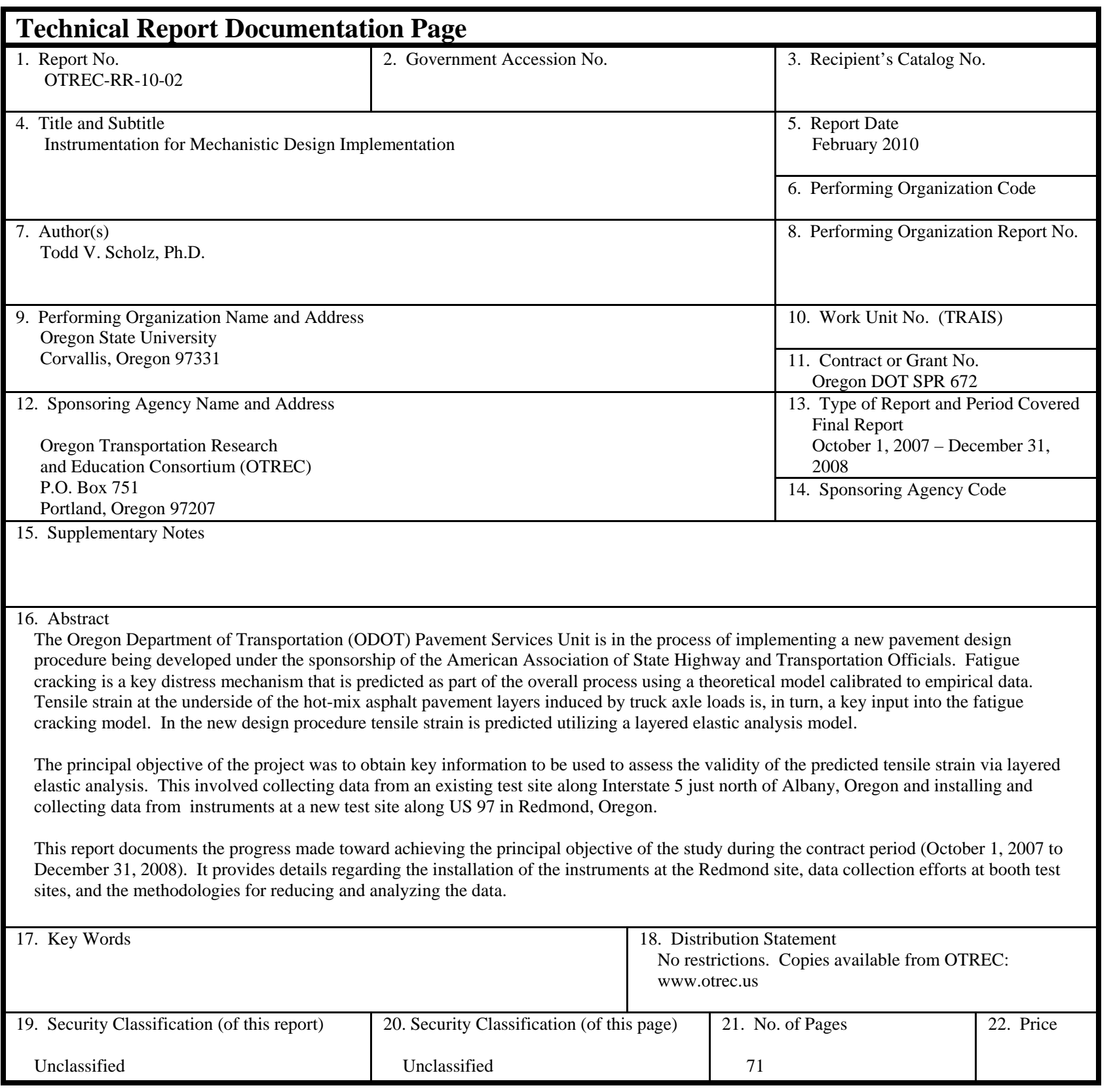




\begin{tabular}{|c|c|c|c|c|c|c|c|c|c|}
\hline \multicolumn{10}{|c|}{ SI* (MODERN MET) } \\
\hline \multicolumn{5}{|c|}{ APPROXIMATE CONVERSIONS TO SI UNITS } & \multicolumn{5}{|c|}{ APPROXIMATE CONVERSIONS FROM SI UNITS } \\
\hline Symbol & When You Know & Multiply By & To Find & Symbol & Symbol & When You Know & Multiply By & To Find & Symbol \\
\hline \multicolumn{5}{|c|}{$\underline{\text { LENGTH }}$} & \multicolumn{5}{|c|}{ LENGTH } \\
\hline in & inches & 25.4 & millimeters & $\mathrm{mm}$ & $\mathrm{mm}$ & millimeters & 0.039 & inches & in \\
\hline $\mathrm{ft}$ & feet & 0.305 & meters & $\mathrm{m}$ & $\mathrm{m}$ & meters & 3.28 & feet & $\mathrm{ft}$ \\
\hline yd & yards & 0.914 & meters & $\mathrm{m}$ & $\mathrm{m}$ & meters & 1.09 & yards & yd \\
\hline $\mathrm{mi}$ & miles & 1.61 & kilometers & $\mathrm{km}$ & $\mathrm{km}$ & kilometers & 0.621 & miles & $\mathrm{mi}$ \\
\hline \multicolumn{5}{|c|}{$\underline{\text { AREA }}$} & \multicolumn{5}{|c|}{ AREA } \\
\hline $\mathrm{in}^{2}$ & square inches & 645.2 & millimeters squared & $\mathrm{mm}^{2}$ & $\mathrm{~mm}^{2}$ & millimeters squared & 0.0016 & square inches & in $^{2}$ \\
\hline $\mathrm{ft}^{2}$ & square feet & 0.093 & meters squared & $\mathrm{m}^{2}$ & $\mathrm{~m}^{2}$ & meters squared & 10.764 & square feet & $\mathrm{ft}^{2}$ \\
\hline $\mathrm{yd}^{2}$ & square yards & 0.836 & meters squared & $\mathrm{m}^{2}$ & ha & hectares & 2.47 & acres & ac \\
\hline ac & acres & 0.405 & hectares & ha & $\mathrm{km}^{2}$ & kilometers squared & 0.386 & square miles & $\mathrm{mi}^{2}$ \\
\hline \multirow[t]{2}{*}{$\mathrm{mi}^{2}$} & square miles & 2.59 & kilometers squared & $\mathrm{km}^{2}$ & \multicolumn{5}{|c|}{ VOLUME } \\
\hline & & \multicolumn{3}{|l|}{ VOLUME } & $\mathrm{mL}$ & milliliters & 0.034 & fluid ounces & $\mathrm{fl} \mathrm{oz}$ \\
\hline $\mathrm{fl} \mathrm{oz}$ & fluid ounces & 29.57 & milliliters & $\mathrm{mL}$ & $\mathrm{L}$ & liters & 0.264 & gallons & gal \\
\hline gal & gallons & 3.785 & liters & $\mathrm{L}$ & $\mathrm{m}^{3}$ & meters cubed & 35.315 & cubic feet & $\mathrm{ft}^{3}$ \\
\hline $\mathrm{ft}^{3}$ & cubic feet & 0.028 & meters cubed & $\mathrm{m}^{3}$ & $\mathrm{~m}^{3}$ & meters cubed & 1.308 & cubic yards & $\mathrm{yd}^{3}$ \\
\hline $\mathrm{yd}^{3}$ & cubic yards & 0.765 & meters cubed & $\mathrm{m}^{3}$ & \multicolumn{5}{|c|}{ MASS } \\
\hline \multicolumn{5}{|c|}{ NOTE: Volumes greater than $1000 \mathrm{~L}$ shall be shown in $\mathrm{m}^{3}$. } & g & grams & 0.035 & ounces & $\mathrm{oz}$ \\
\hline \multicolumn{5}{|c|}{$\underline{\text { MASS }}$} & $\mathrm{kg}$ & kilograms & 2.205 & pounds & $\mathrm{lb}$ \\
\hline $\mathrm{oz}$ & ounces & 28.35 & grams & g & $\mathrm{Mg}$ & megagrams & 1.102 & short tons (2000 lb) & $\mathrm{T}$ \\
\hline $\mathrm{lb}$ & pounds & 0.454 & kilograms & $\mathrm{kg}$ & \multicolumn{5}{|c|}{ TEMPERATURE (exact) } \\
\hline $\mathrm{T}$ & short tons (2000 lb) & 0.907 & megagrams & $\mathrm{Mg}$ & \multirow[t]{3}{*}{${ }^{\circ} \mathrm{C}$} & Celsius temperature & $1.8+32$ & Fahrenheit & \multirow[t]{3}{*}{${ }^{\circ} \mathrm{F}$} \\
\hline \multicolumn{5}{|c|}{ TEMPERATURE (exact) } & & \multirow{2}{*}{\multicolumn{3}{|c|}{ 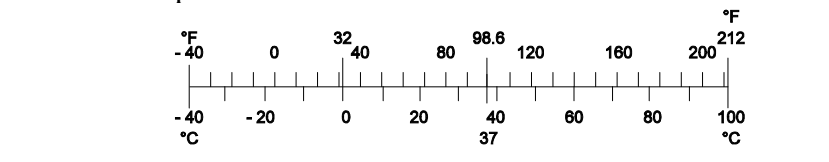 }} & \\
\hline${ }^{\circ} \mathrm{F}$ & $\begin{array}{l}\text { Fahrenheit } \\
\text { temperature }\end{array}$ & $5(\mathrm{~F}-32) / 9$ & Celsius temperature & ${ }^{\circ} \mathrm{C}$ & & & & & \\
\hline \multicolumn{5}{|c|}{ * SI is the symbol for the International System of Measurement } & & & & & $(4-7-$ \\
\hline
\end{tabular}





\section{ACKNOWLEDGEMENTS}

This project was funded by the Oregon Transportation Research and Education Consortium (OTREC), the Oregon Department of Transportation, and the Federal Highway Administration. The author would like to thank the members of the ODOT Research Unit for their advice and assistance in the preparation of this report.

\section{DISCLAIMER}

The contents of this report reflect the views of the authors, who are solely responsible for the facts and the accuracy of the material and information presented herein. This document is disseminated under the sponsorship of the U.S. Department of Transportation University Transportation Centers Program, the Oregon Department of Transportation, and the Federal Highway Administration in the interest of information exchange. The U.S. Government and the Oregon Department of Transportation assumes no liability for the contents or use thereof. The contents do not necessarily reflect the official views of the U.S. Government and the Oregon Department of Transportation. This report does not constitute a standard, specification, or regulation. 


\section{TABLE OF CONTENTS}

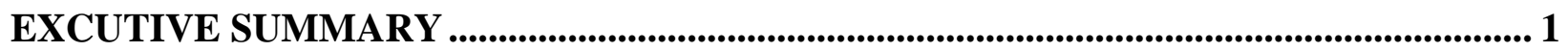

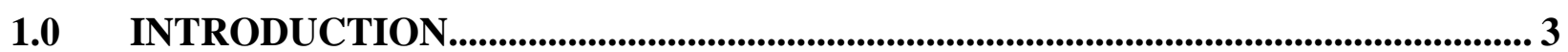

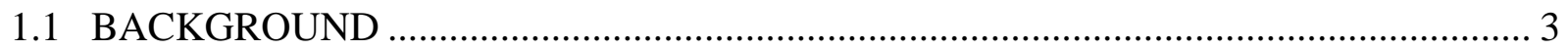

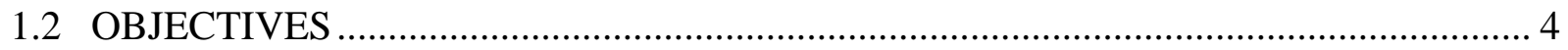

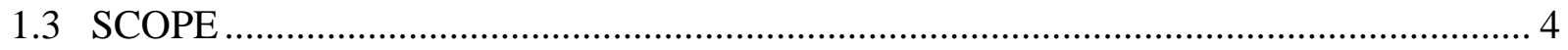

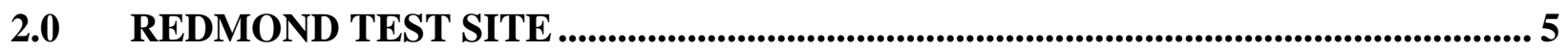

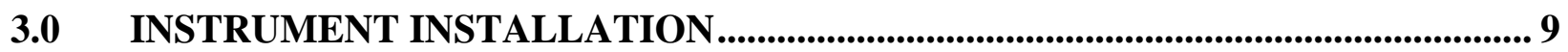

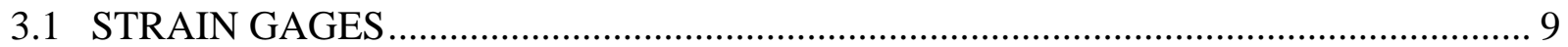

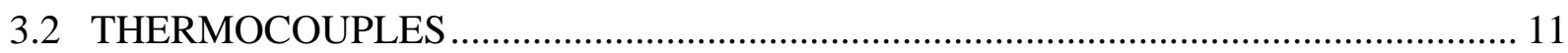

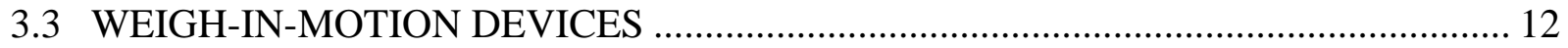

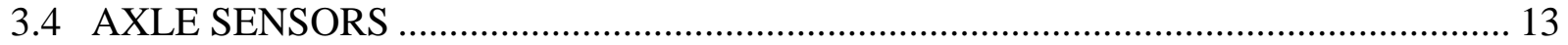

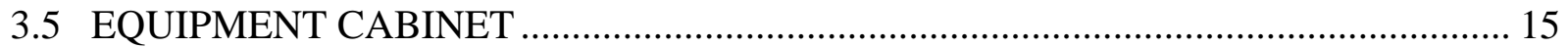

3.6 DATA ACQUISITION SYSTEM AND SOFTWARE................................................. 16

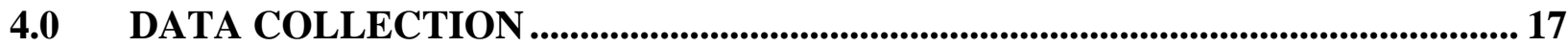

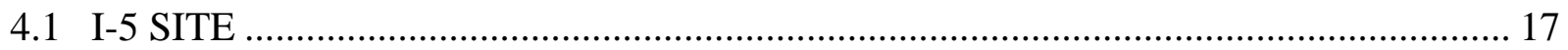

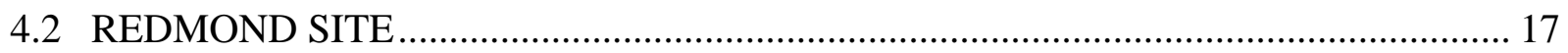

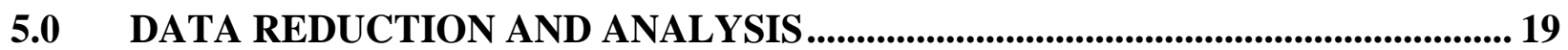

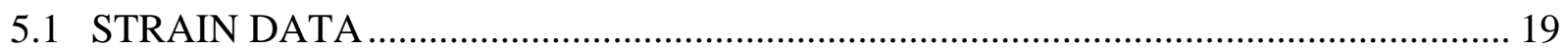

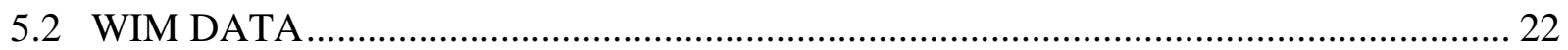

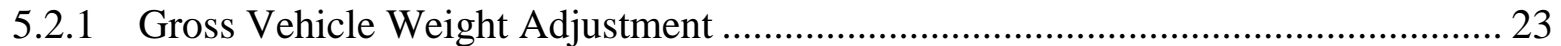

5.2.2 Axle Weight Adjustment ................................................................................ 23

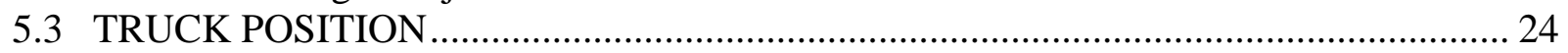

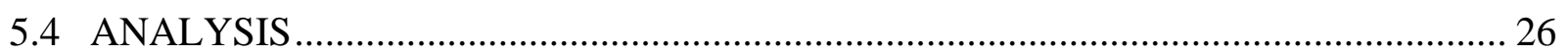

6.0 CONCLUSIONS AND RECOMMENDATIONS.................................................. 29

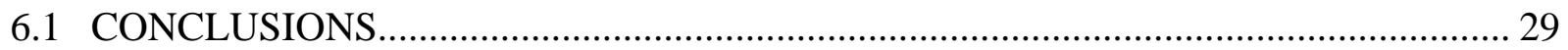

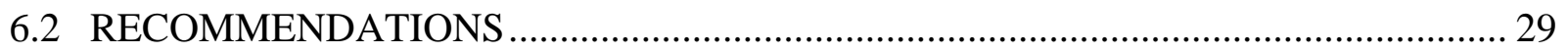

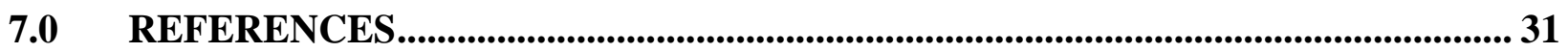

\section{APPENDICES}

APPENDIX A: I-5 TEST SITE

APPENDIX B: I-5 TEST SITE DATA (REDUCED) 


\section{LIST OF TABLES}

Table 5.1: Measured tensile strain induced by the axle loads of a five-axle truck (I-5 site) .........26

\section{LIST OF FIGURES}

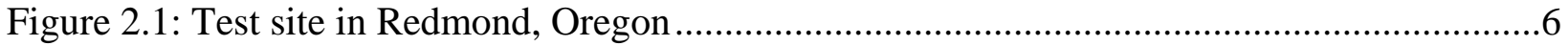

Figure 2.2: Redmond test site location at the south end of the US 97 reroute project ..................6

Figure 2.3: Pavement structure at the Redmond test site...................................................

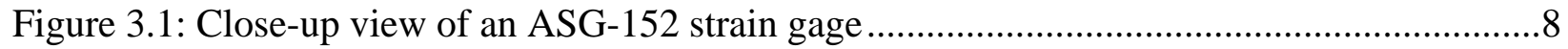

Figure 3.2: Strain gage array over the aggregate base course at the Redmond test site .................9

Figure 3.3: Distances between strain gages at the Redmond site ...........................................9

Figure 3.4: Partial construction sequence at the Redmond site ..............................................10

Figure 3.5: Depth of thermocouples installed in the HMA layer at the Redmond test site...........11

Figure 3.6: Weigh-in-motion (WIM) devices installed on the surface of the pavement ...............11

Figure 3.7: Axle sensors installed on the surface of the pavement.........................................12

Figure 3.8: Geometric layout of the axle sensors .................................................................12

Figure 3.9: Geometric layout of axle sensors for determining the lateral position of a vehicle....13

Figure 3.10: Equipment cabinet at the Redmond test site .................................................14

Figure 3.11: Schematic of offset trimmer used to null out strain gage bridge..............................15

Figure 5.1: Typical set of data obtained from the longitudinal strain gages...............................19

Figure 5.2: Typical set of data obtained from the transverse strain gages.................................20

Figure 5.3: Methodology for reducing the longitudinal strain gage data ...................................21

Figure 5.4: Methodology for reducing the transverse strain gage data......................................22

Figure 5.5: Photographic method of determining truck position .............................................25

Figure 5.6: Windows version of JULEA developed by USACE ERDC-WES ..........................27 


\section{EXCUTIVE SUMMARY}

The Oregon Department of Transportation (ODOT) Pavement Services Unit is in the process of adopting the new pavement design procedure being developed under the sponsorship of the American Association of State Highway and Transportation Officials (AASHTO). Fatigue cracking in hot-mix asphalt (HMA) pavements is one of the key distress mechanisms that is predicted as part of the overall process using a theoretical model calibrated using empirical data. The model has been calibrated using national data from the Long-Term Pavement Performance (LTTP) program, but not for Oregon-specific conditions.

In general, calibration involves comparing predicted performance from the model with measured performance from in-service pavements. Adjustments to parameters in the model are then made so that the predicted performance matches the actual performance within a chosen degree of accuracy. One key input into the fatigue cracking model is tensile strain at the underside of the of the HMA layers where fatigue cracking initiates in the vast majority of HMA pavements. Prior to calibrating the fatigue cracking model in its entirety, ODOT set out to firstly validate the prediction of tensile strain at the bottom of the HMA layer. JULEA is the layered elastic analysis program utilized in the new design procedure for the prediction of tensile strain to be used as input into the fatigue cracking model.

In 2005, ODOT initiated the process of obtaining the necessary measurements from two pavement sections along Interstate 5 (I-5) just north of Albany, Oregon. In late summer 2008, an additional site along US 97 in Redmond, Oregon was instrumented for these same purposes.

Several attempts were made to collect data from the I-5 test site. However, due to equipment malfunctions, personnel turnover, and unavailability of qualified personnel, only one data collection effort was successful. These data were fully reduced and included herein. Although reduction of the data from the I-5 test site was completed, lack of all information necessary to develop predicted values prevented a comparison between measured and predicted values.

Due to the lateness of establishing the Redmond test site, data were collected only once from the site. These data were only partially reduced. Hence, these data are not included herein.

Despite the difficulties encountered at the I-5 tests site and the lateness in establishing the Redmond site, progress was made with regard to data collection efforts. That is, development of customized software was initiated for this purpose. Progress was also made in that the truck positions derived from surface instruments were verified with the truck positions derived from photographs. Development of enhanced data reduction tools was also initiated to reduce the required amount of human interaction and, therefore, the time required to complete the process. 


\subsection{INTRODUCTION}

\subsection{BACKGROUND}

The Oregon Department of Transportation (ODOT) Pavement Services Unit is in the process of implementing a new pavement design procedure based on empirical and mechanistic procedures in preparation for eventual adoption of the new procedure being developed under the sponsorship of the American Association of State Highway and Transportation Officials (AASHTO). In both procedures, fatigue cracking is a key distress mechanism that is predicted as part of the overall process using a theoretical model calibrated using empirical data. For the AASHTO procedure, the model has been calibrated using national data from the Long-Term Pavement Performance (LTTP) program, whereas the model has not yet been calibrated for Oregon-specific conditions.

Part of the process for successful implementation of the new procedure is calibration of the design process such that the theory behind the process can be accurately related to actual performance - that is, match predicted values (theory) to what happens in the field (actual performance). Currently, several assumptions about the response of pavement structures due to actual loading (principally, responses due to truck loading) are necessary to develop an appropriate design. Actual responses (i.e., performance) can only be verified through an investigation of the engineering properties of the materials used during construction coupled with measurement of their response to actual (in-service) loading conditions.

Due to the enormity of calibrating the new design procedure in its entirety, ODOT chose to firstly validate the process in a stepwise fashion. In 2005, ODOT initiated the process of obtaining the necessary measurements for verifying one of the key responses of the pavement structure-induced tensile strain at the bottom of the HMA layer-due to in-service loading by installing instruments within two hot-mix asphalt (HMA) pavement sections near Albany, Oregon in the southbound, outside (slow) lane of Interstate 5 (I-5). Measurements from the instruments have been obtained periodically to validate the prediction (by layered elastic analysis software) of tensile strain, which is a key input into the fatigue cracking model of the new design procedure.

ODOT builds and maintains highways of varying structural capacity in a diverse range of climatic regions (i.e., coastal, intermountain, mountainous, and high desert) that are subjected to a wide range of truck traffic volumes. Hence, it was decided that additional test sections were needed to validate the prediction of tensile strain for a wider range of conditions than just those for the test sections along Interstate 5. In particular, the goal was to include pavement test sections with varying structural capacities, in differing climatic regions within the state, and subjected to a range of truck traffic levels and speeds. 


\subsection{OBJECTIVES}

The principal objective of the research project was to obtain key information (i.e., engineering properties of the materials used for construction and in-service response of these materials to applied truck loads) to be used to assess the validity of predicted tensile strain via layered elastic analysis. More specifically, the objectives of the project were to:

1. Instrument three new HMA pavements with differing structure and truck traffic volume, and constructed in differing climatic conditions such that pavement response due to truck loading could be measured periodically throughout the year.

2. Conduct necessary field testing and obtain field samples for laboratory testing.

3. Conduct the necessary laboratory tests on the samples obtained from the test sites.

4. Collect data from the instrumented test sites.

5. Use the data collected from the instrumented pavements (i.e., axle loads, axle configurations and/or truck classification, induced tensile strain, and pavement temperature) as well as information derived from laboratory tests conducted on the field samples to validate tensile strain prediction via layered elastic analysis for the range of pavement structures, truck traffic volumes, and climatic conditions investigated.

\subsection{SCOPE}

This report documents the progress made toward achieving the objectives identified above during the period from October 1, 2007 to September 30, 2008 (with a 3-month, no-cost extension to December 31, 2008). It should be noted that the contract for the project was awarded to Oregon State University in November of 2007, by which time construction of statesponsored hot-mix asphalt pavements had ceased until the following construction season (i.e., summer of 2008). Hence, field work toward achieving the first objective was not accomplished until near the end of the original contract period. 


\subsection{REDMOND TEST SITE}

In addition to the Interstate 5 test site established in 2005 (see Appendix A), consideration was given to several additional sites to instrument; namely, I-5 just south of Medford, I-5 in Portland (Delta Park Project), Highway 213 near Molalla, Highway 58, Highway 140 between Klamath Falls and Lakeview, US 101 near Bandon, and US 97 in Redmond. Of these additional sites, only the US 97 site in Redmond was instrumented. The principal reasons for not installing instruments at the other sites included:

- $\quad$ The I-5 Medford project site would have essentially duplicated the I-5 site near Albany (i.e., similar pavement structure and similar truck traffic volume).

- The portion of the I-5 Portland (Delta Park) project that was to be instrumented was not paved during the 2008 construction season. This remains a potential site for instrumentation.

- The Highway 213 site near Molalla was determined to have an insufficient volume of heavy truck traffic to warrant the effort and expense of installing instruments at the site.

- On Highway 58, the sites considered included sections at bridge approaches but these eliminated from further consideration due to difficulties in compacting these sections and thus establishing a site with an HMA layer that would not be representative of mainline pavement sections.

- The project on Highway 140 involved partial removal of the HMA prior to placing an overlay. Thus, to utilize this site the strain gages would have been installed on top of the milled HMA surface prior to placement of the overlay (i.e., sandwiched between the overlay and the remaining HMA following the milling operation) creating an instrument arrangement that would not have measured the desired strain at the underside of the entire HMA layer.

- The project on US 101 was eliminated due to an insufficient volume of heavy truck traffic to warrant the effort and expense of installing instruments at the site.

Redmond is in the high desert climatic region in central Oregon. Figure 2.1 illustrates the general location of the test site while Figure 2.2 shows that the test site is located at the south end of the US 97 reroute (bypass) around downtown Redmond. The instruments were installed in the southbound, outside lane about 2,000 feet north of Sisters Avenue. The project involved construction of new pavement along the new alignment designed for moderate truck traffic. Figure 2.3 illustrates the pavement structure at the Redmond test site. 


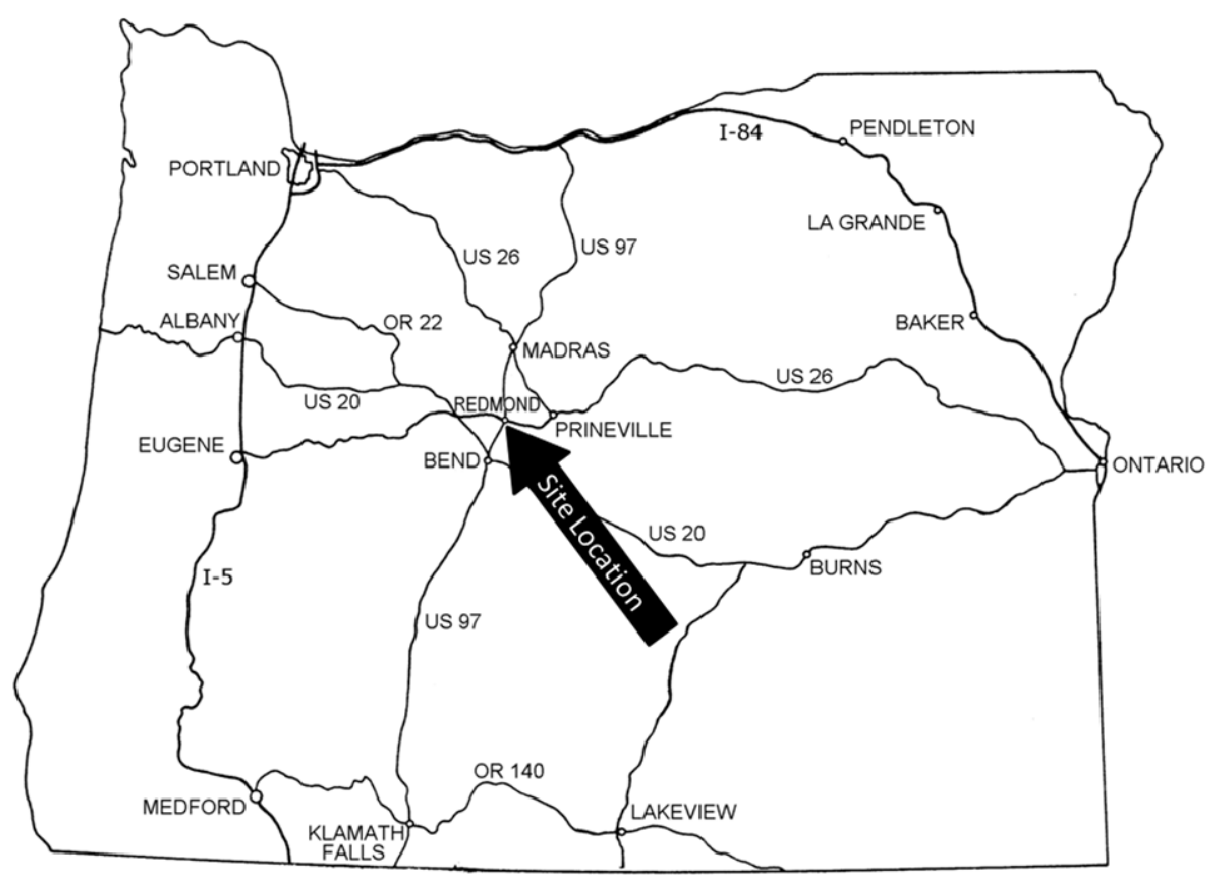

Figure 2.1: Test site in Redmond, Oregon.

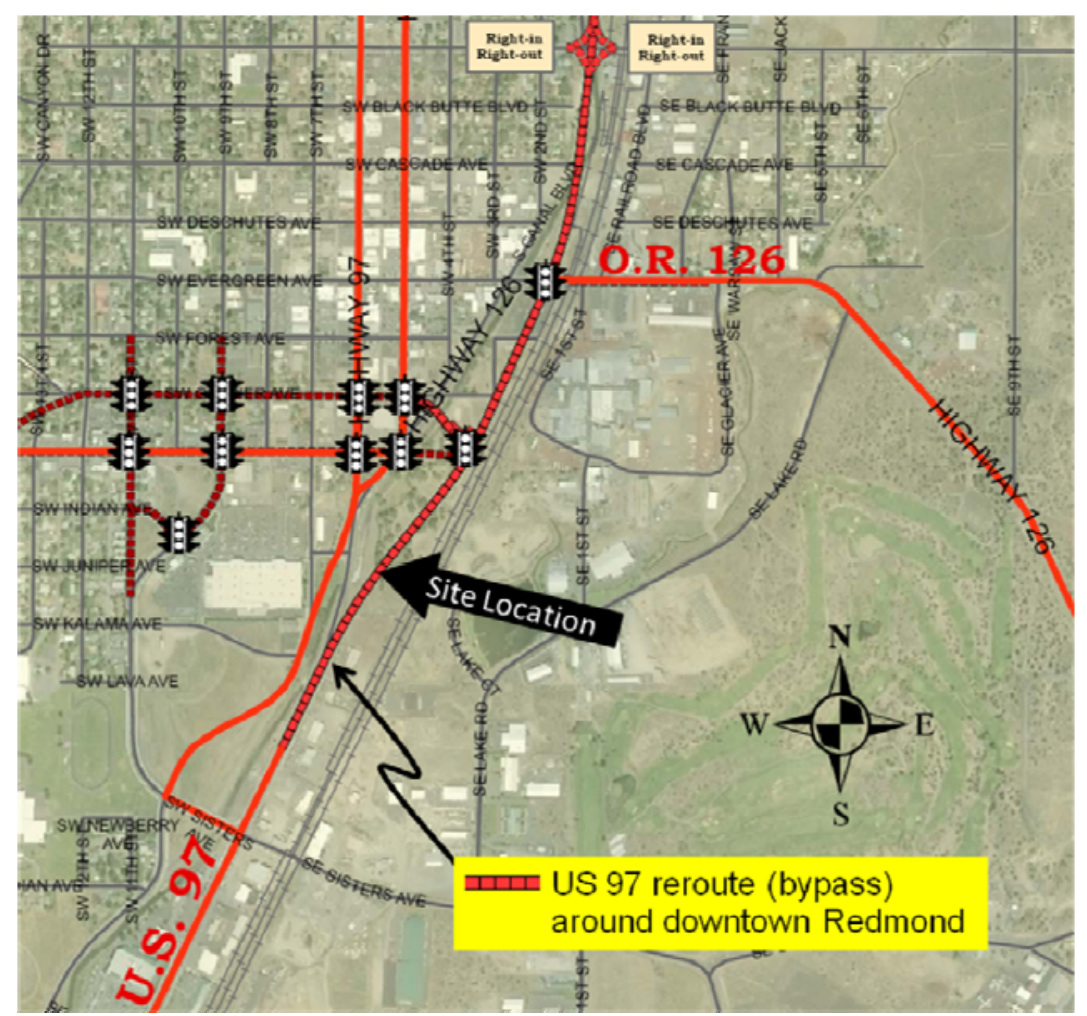

Figure 2.2: Redmond test site location at the south end of the US 97 reroute project. 


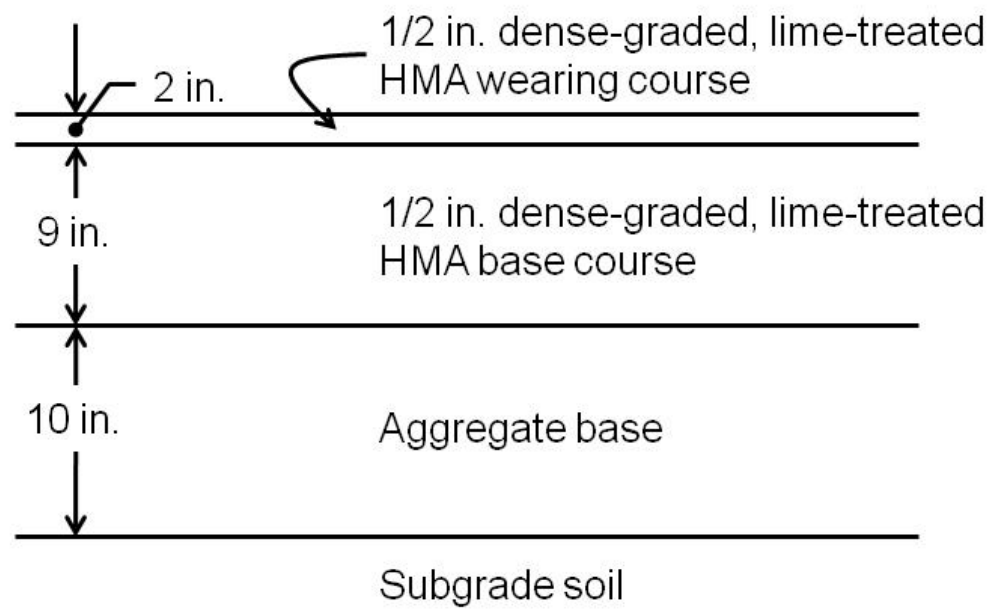

Figure 2.3: Pavement structure at the Redmond test site. 


\subsection{INSTRUMENT INSTALLATION}

Instruments were placed within the pavement structure during construction and on the surface of the pavement following construction. Instruments installed within the pavement structure included strain gages and thermocouples, whereas instruments installed on the pavement surface included weigh-in-motion (WIM) devices and axle sensors. The following sections provide a brief description of the installation of these instruments.

\subsection{STRAIN GAGES}

CTL Group ASG-152 strain gages (Figure 3.1) were installed at the Redmond site on June 17 and 18, 2008. An array of nine gages was installed on the surface of the aggregate base course as shown in Figure 3.2. As indicated in the photo, six gages were oriented to measure longitudinal strain and three gages were oriented to measure transverse strain. Figure 3.3 illustrates the distances between the strain gages.

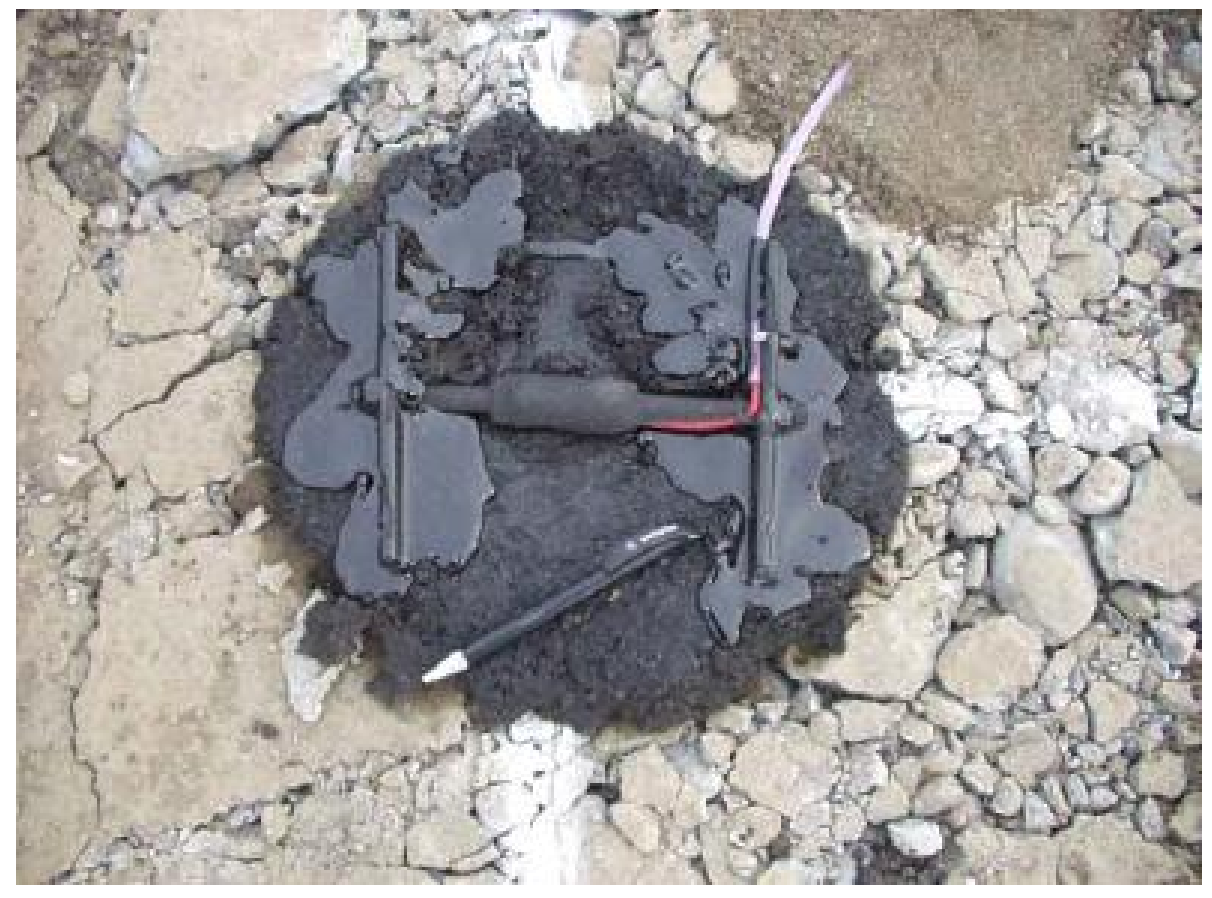

Figure 3.1: Close-up view of an ASG-152 strain gage. 


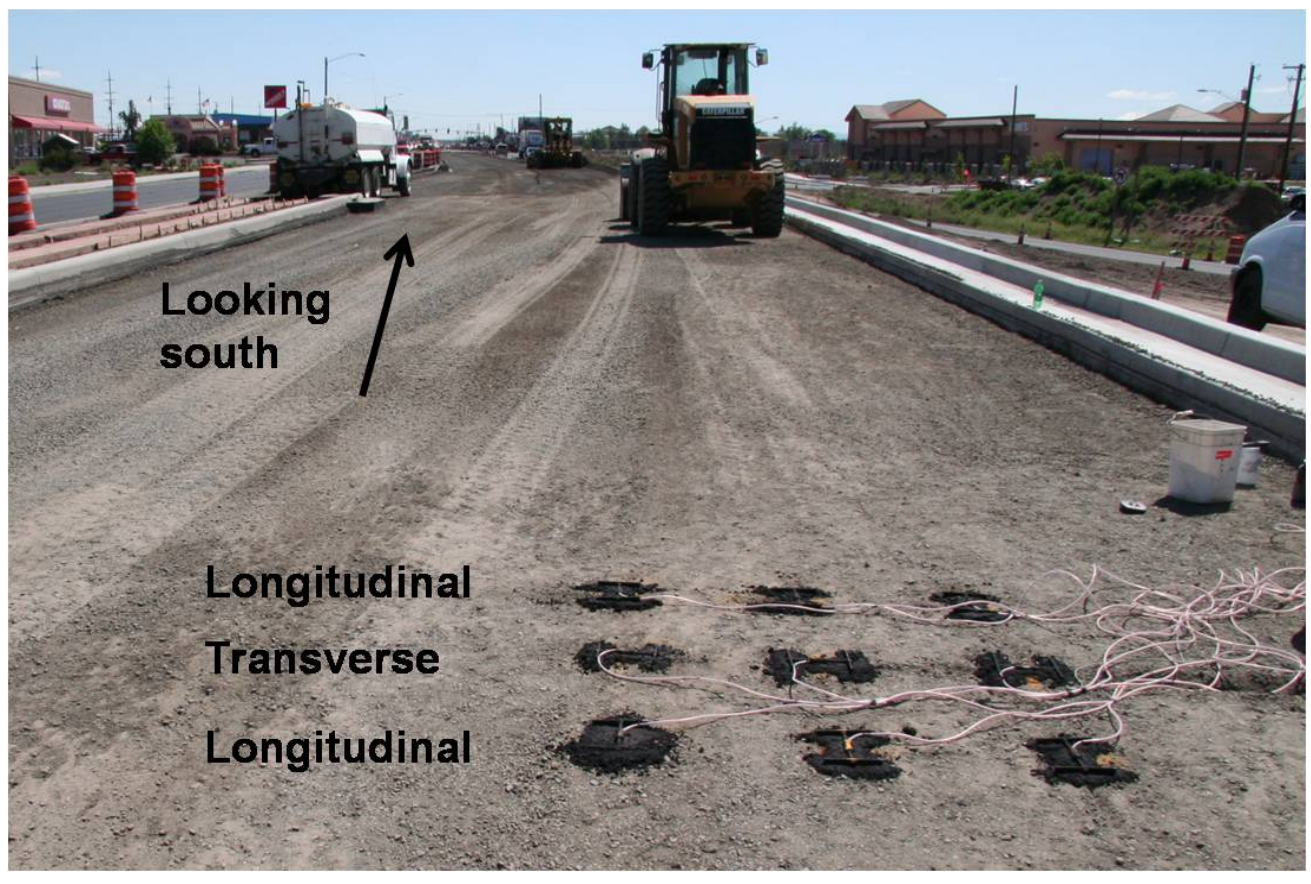

Figure 3.2: Strain gage array over the aggregate base course at the Redmond test site.

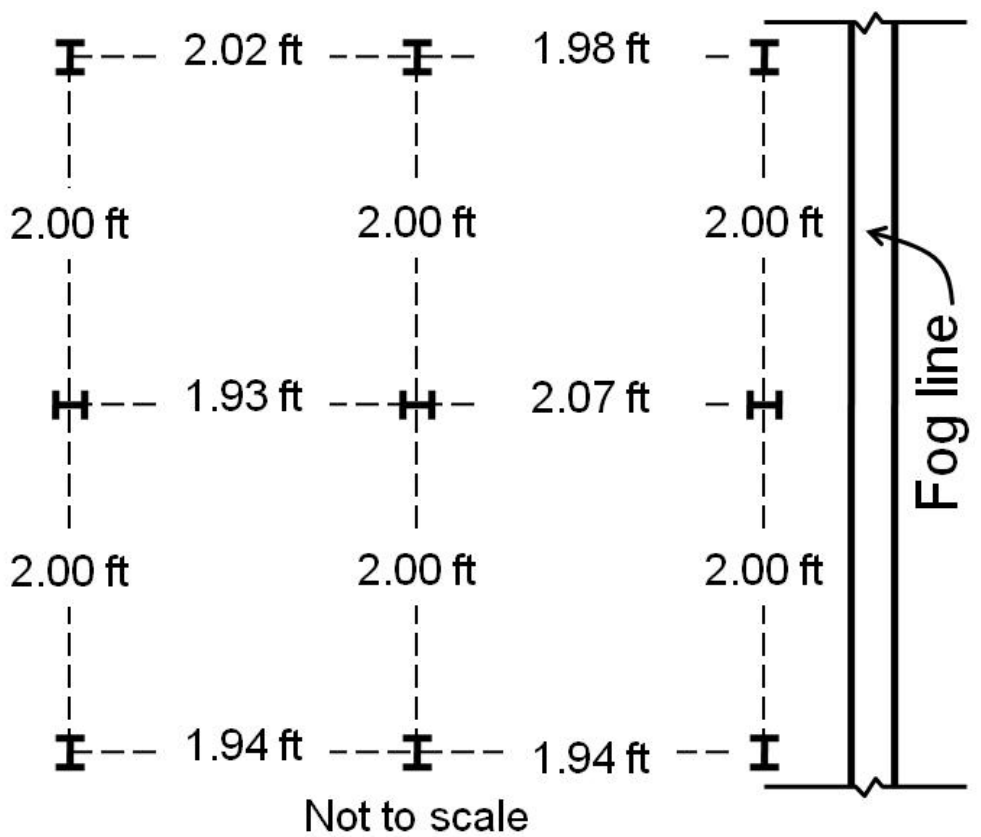

Figure 3.3: Distances between strain gages at the Redmond site. 
The strain gages were given a protective covering of cold-mix asphalt prior to placement of the first lift of hot-mix asphalt. HMA was then placed directly over the protected gages in a windrow (Figure 3.4a) which was picked with an elevator attached to the paving machine (Figure 3.4b), followed by compaction with a heavy roller (Figure 3.4c).

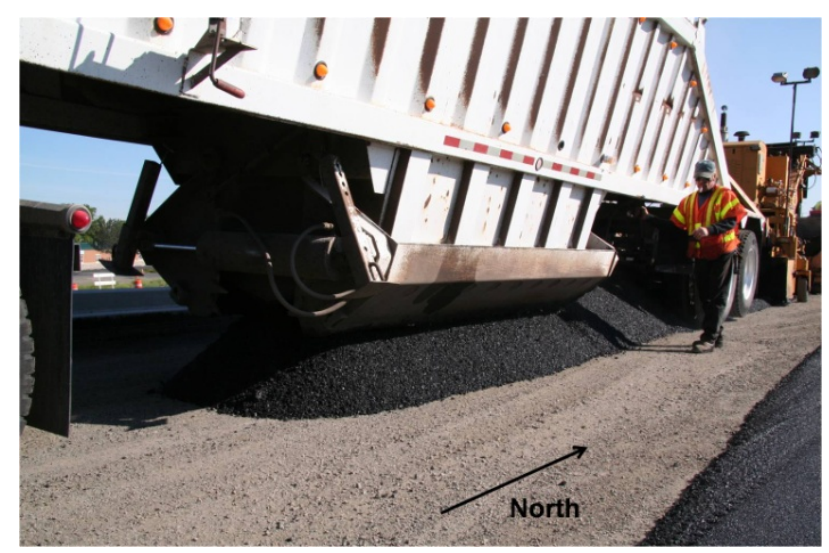

a) HMA windrow placed directly over partially protected gages.

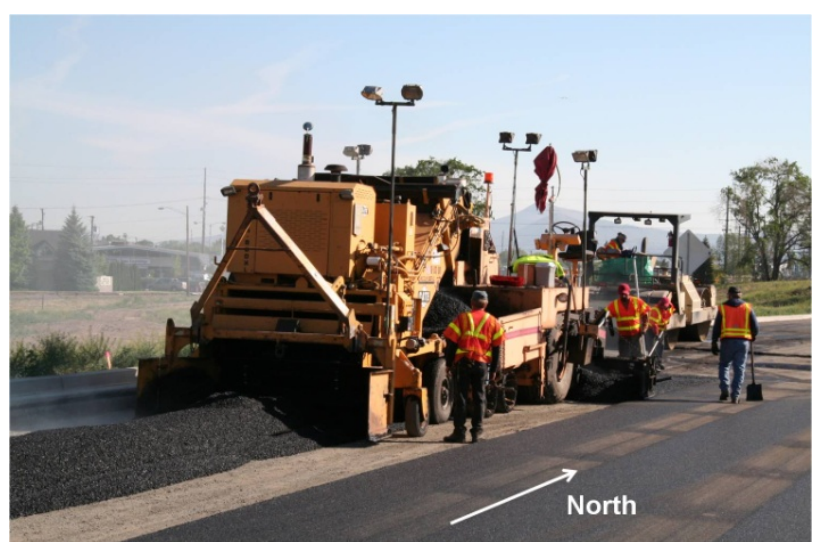

b) Windrow elevator attached to paver.

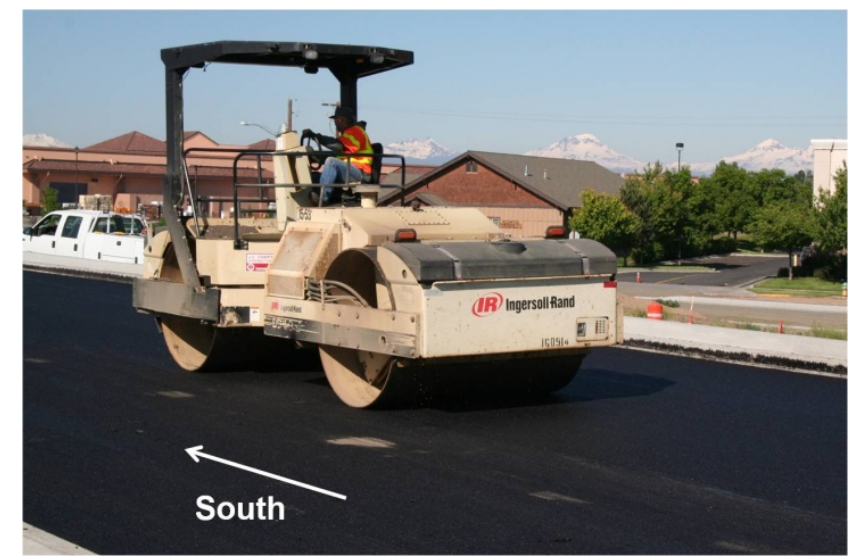

c) Compacting the first lift of HMA with a heavy roller.

Figure 3.4: Partial construction sequence at the Redmond site.

\subsection{THERMOCOUPLES}

Thermocouples were installed at various depths within the hot-mix asphalt layer at the Redmond test site as illustrated in Figure 3.5. Installation occurred following construction and involved drilling holes to the appropriate depths, inserting the thermocouples, and filling the holes with epoxy. The thermocouples allowed monitoring of the HMA temperature with depth to an accuracy of at least $0.2^{\circ} \mathrm{F}\left(0.1^{\circ} \mathrm{C}\right)$. 


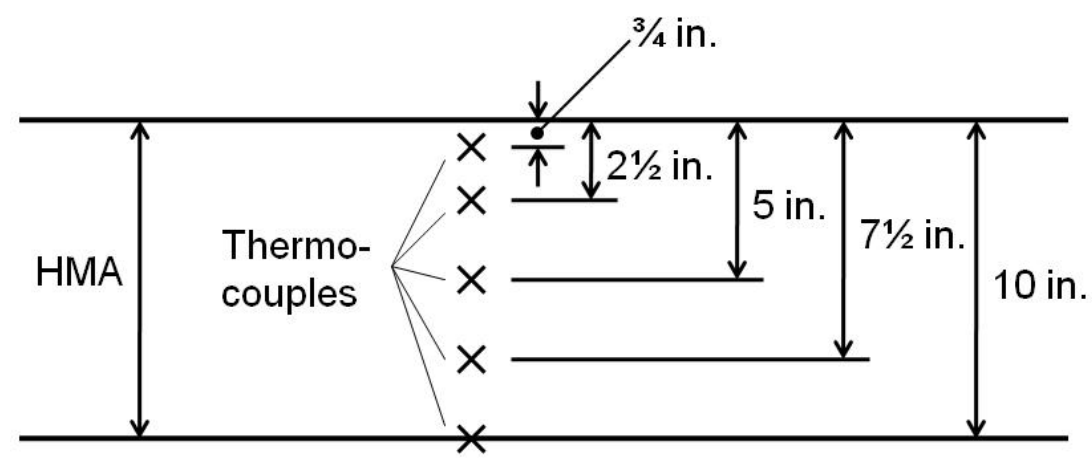

Figure 3.5: Depth of thermocouples installed in the HMA layer at the Redmond test site.

\subsection{WEIGH-IN-MOTION DEVICES}

Following construction, weigh-in-motion (WIM) devices were installed on the surface of the HMA layer during the evening of August 22 and early morning of August 23, 2008. These included two piezoelectric strips and an induction loop as shown in Figure 3.6. A thermocouple was also installed under one of the piezoelectric strips (at 1 inch depth). The piezoelectric strips were used to measure axle loads and velocities of the vehicles crossing the strips, the induction loop was used to classify the vehicles, and the thermocouple was used to measure temperature. Installation involved cutting grooves in the surface of the pavement, cleaning and drying the grooves, placing the devices in the grooves, and filling the grooves with adhesive-epoxy for the piezoelectric strips and thermocouple and liquid asphalt for the induction loops-around the devices. The WIM devices were installed upstream of the strain gages.

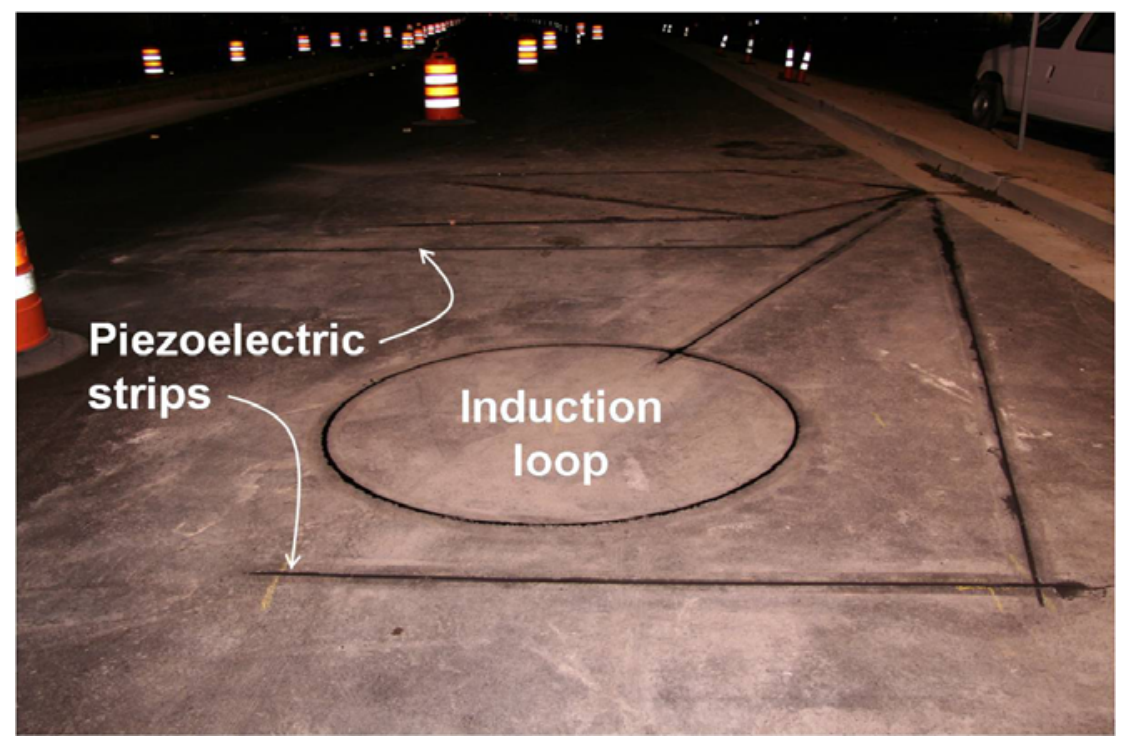

Figure 3.6: Weigh-in-motion (WIM) devices installed on the surface of the pavement. 


\subsection{AXLE SENSORS}

Axle sensors were also installed on the surface of the pavements at the test site (Figure 3.7) following construction to determine the transverse position of vehicles in the travel lane. Installation involved cutting grooves in the surface of the pavement, cleaning and drying the grooves, placing the devices in the grooves, and filling the grooves with epoxy adhesive around the devices. Figure 3.8 illustrates the geometric layout of the axle sensors. The installation of the axle sensors was accomplished approximately 2 months after the strain gages were installed.

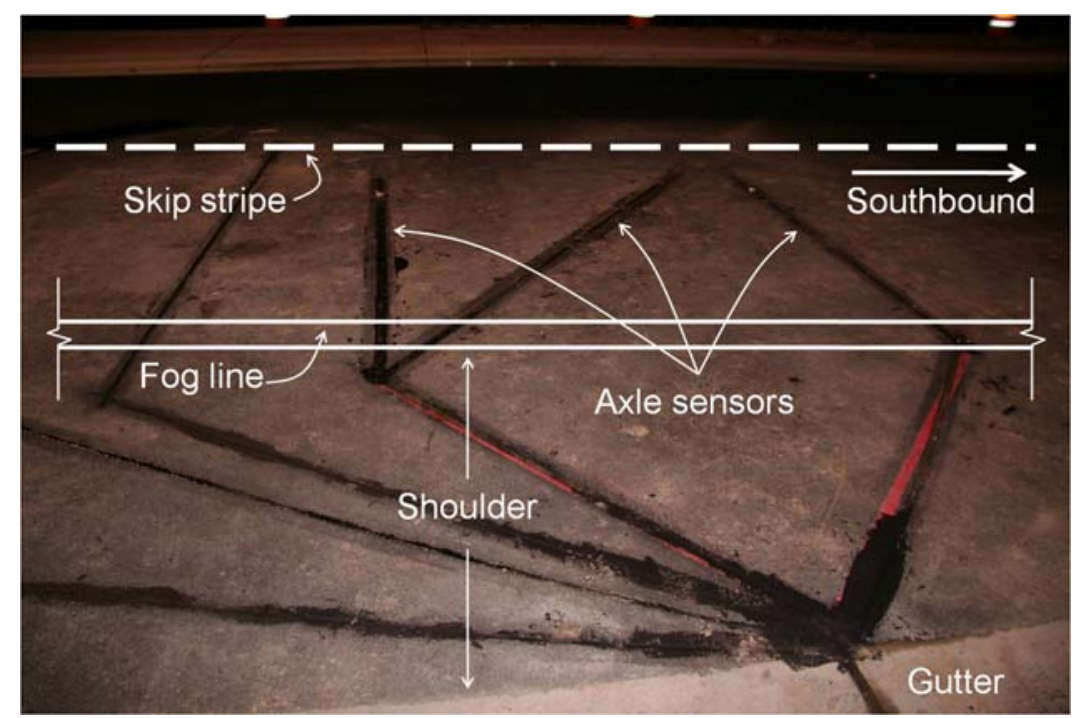

Figure 3.7: Axle sensors installed on the surface of the pavement.

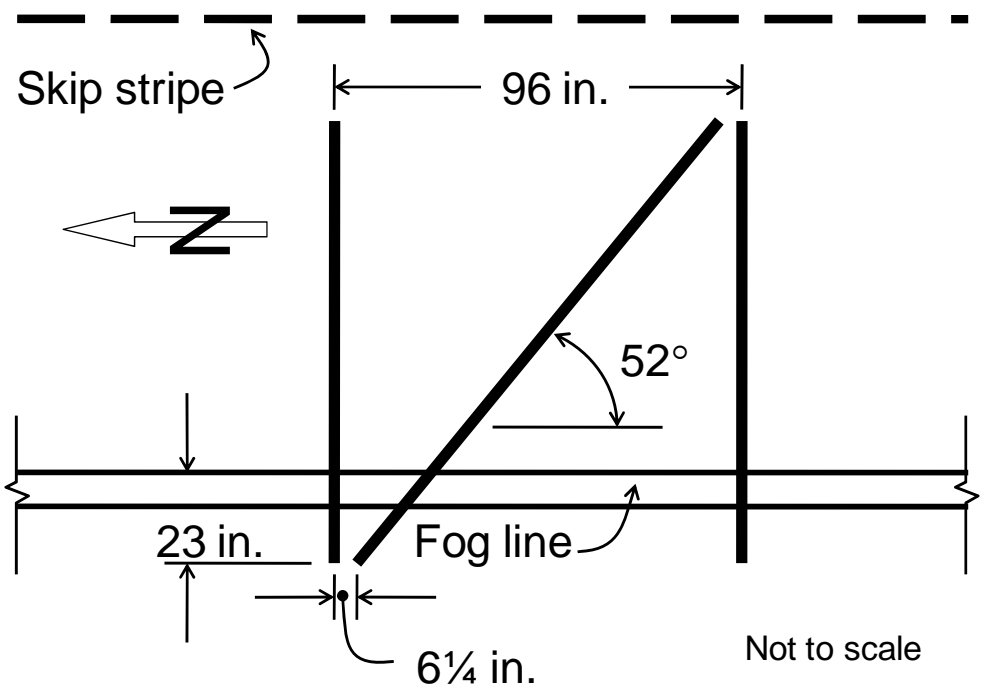

Figure 3.8: Geometric layout of the axle sensors. 
With the assistance of Figure 3.9 it can be shown that, knowing the geometric layout of the axle sensors as well as the time stamps, $t_{i}$, of a vehicle travelling over the sensors, the lateral (transverse) position of the vehicle, $y^{\prime}$, can be determined. The following derivation for $y$ ' is paraphrased from Timm and Priest (1).

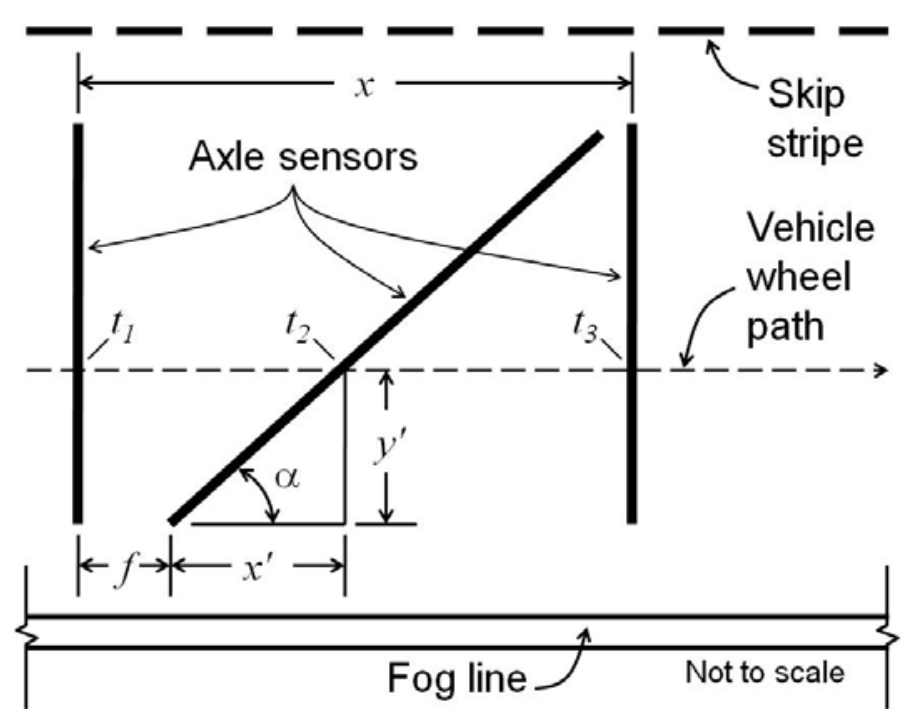

Figure 3.9: Geometric layout of axle sensors for determining the lateral position of a vehicle.

The average velocity, $v_{1}$, of the vehicle between the upstream sensor and the point at which it crosses the angled sensor can be expressed by:

$$
v_{1}=\frac{f+x^{\prime}}{t_{2}-t_{1}}
$$

The average velocity, $v_{2}$, of the vehicle between the upstream and downstream sensors can be expressed by:

$$
v_{2}=\frac{x}{t_{3}-t_{1}}
$$

Assuming essentially constant speed of the vehicle as it crosses the sensors (i.e., $v_{1}=v_{2}=$ constant), Equations 3-1 and 3-2 can be equated and solved for $x$ ' as follows:

$$
x^{\prime}=x\left(\frac{t_{2}-t_{1}}{t_{3}-t_{1}}\right)-f
$$


Given that the middle sensor is oriented at angle $\alpha$, it can be seen that:

$$
\tan \alpha=\frac{y^{\prime}}{x^{\prime}}
$$

Substituting Equation 3-3 into Equation 3-4 and solving for $y$ ' yields:

$$
y^{\prime}=(\tan \alpha)\left[x\left(\frac{t_{2}-t_{1}}{t_{3}-t_{1}}\right)-f\right]
$$

\subsection{EQUIPMENT CABINET}

An equipment cabinet was installed at the site a safe distance from the highway (i.e., live traffic) to house the equipment necessary for data acquisition. Instrument cables (wires) were routed from the roadway to the equipment cabinet through a trench to prevent damage by traffic, weather, and maintenance equipment. Figure 3.10 shows a picture of the equipment cabinet installed at the Redmond test site.

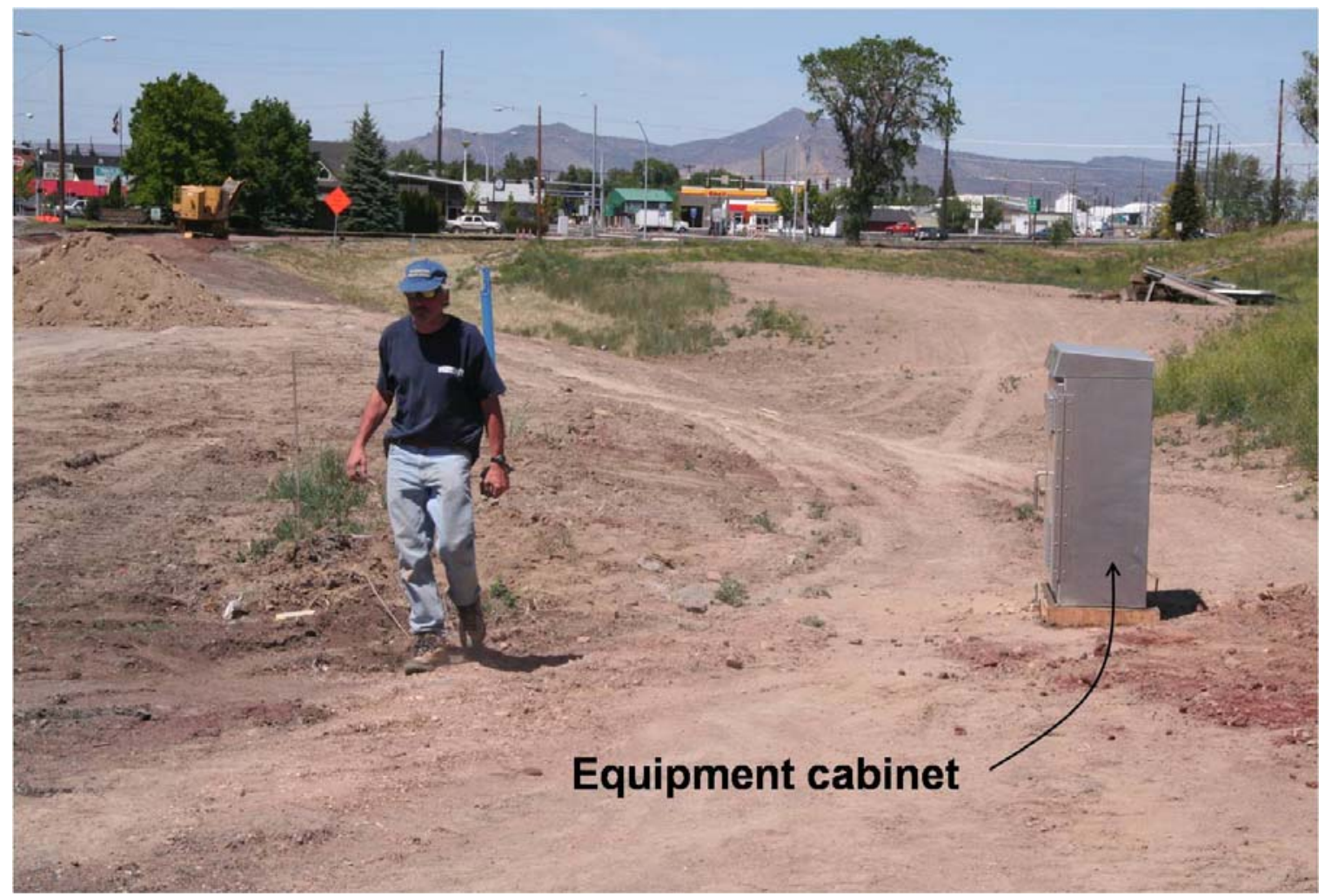

Figure 3.10: Equipment cabinet at the Redmond test site. 


\subsection{DATA ACQUISITION SYSTEM AND SOFTWARE}

An IOtech StrainBook/616 data acquisition unit with two IOtech WBK16 expansion units providing 24 channels of input was used for measuring strain. The IOtech WaveView software was initially used for configuring the data acquisition unit and for retrieving the strain data from it. Despite many efforts to utilize this software, it proved to be difficult to use and quite limited in capabilities. Hence, OSU personnel initiated development of a custom software package utilizing LabView.

In addition, due to the large quiescent strain in the strain gages and limitations of the data acquisition system, each input cable into the data acquisition unit required modification to allow removal of the quiescent strain offset. This entailed inserting a circuit (offset trimmer) comprised of a shunt resistor and potentiometer between the strain gage bridge and StrainBook as shown in Figure 3.11. Adjusting the potentiometer allowed removal of the voltage offset associated with the quiescent strain, which could not be accomplished through configuration of the system using the WaveView or LabView software. The StrainBook was also used to determine the time stamps at which a particular vehicle crossed each of the axle sensors (Section 3.4), but the offset trimmers were not required for this purpose.

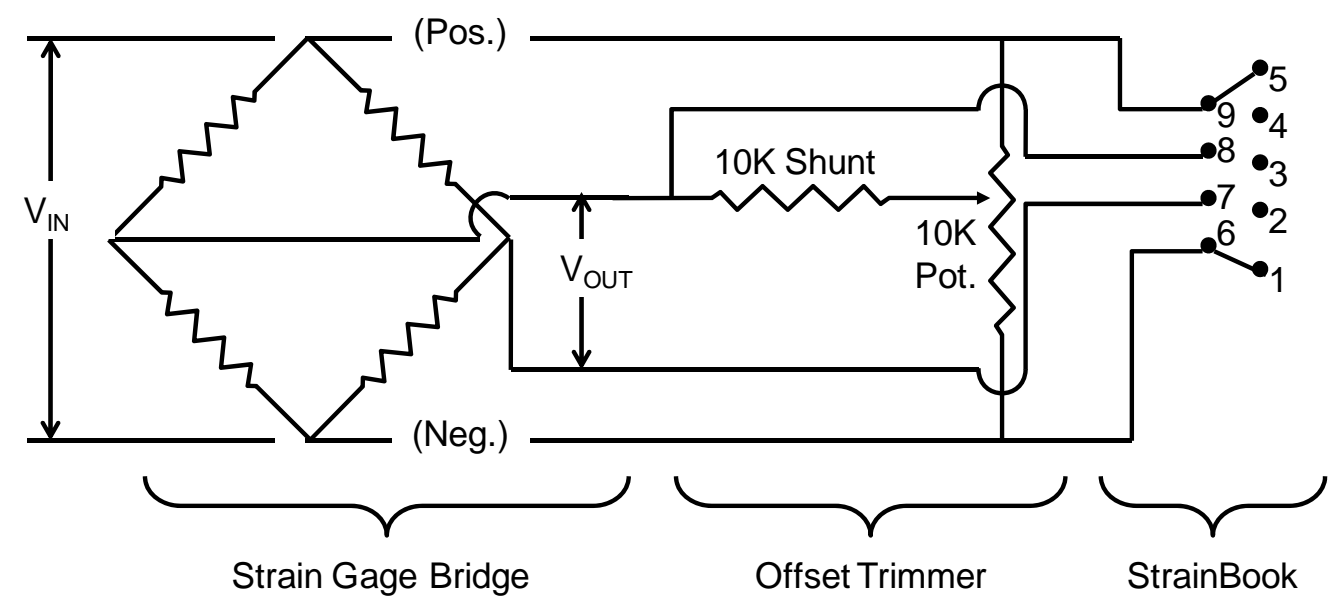

Figure 3.11: Schematic of offset trimmer used to null out strain gage bridge.

A DAW 100 data acquisition unit manufactured by International Road Dynamics (IRD), Inc. was used to measure gross vehicle weight, individual axle loads, vehicle classification, vehicle speed, and pavement temperature at 1 inch depth. Software developed by IRD was used to acquire the data from the data acquisition unit.

Temperature data from the thermocouples (other than from the thermocouple under the WIM piezoelectric strip) were collected using a digital multimeter. Temperature data were usually obtained once per site visit. 


\subsection{DATA COLLECTION}

Data collection involved acquiring WIM data (gross vehicle weight, individual axle loads, vehicle classification, vehicle speed, and pavement temperature at 1 inch depth), data from each strain gage, transverse position of the vehicle within the lane via the axle sensors, and pavement temperature with depth via the thermocouples. Typically, data from at least 100 trucks with at least five axles were collected during each site visit (smaller trucks and passenger vehicles were ignored). Data were collected on laptop computers and later transferred to a network server at OSU. The following paragraphs identify the dates when data were collected from each test site.

\subsection{I-5 SITE}

Data collection from the I-5 site was attempted several times. In all but one case the WIM data acquisition unit malfunctioned; thus, data were collected successfully on only one occasion. It should be noted here that the WIM data acquisition unit was an old system salvaged from a previous study. Being an old system, it frequently failed to function properly out in the field despite having been bench tested successfully in the laboratory. Problems with the electronic boards, cable connections, and power supply were the principal reasons for the malfunctions. In addition, personnel turnover in the spring and the lack of qualified personnel over the summer months also significantly impacted the ability to obtain data.

Axle sensor data were still collected during the occasions that the WIM data acquisition unit malfunctioned. In addition, photos of trucks were taken from the overpass immediately upstream of the instrumented site to verify the transverse position of the trucks derived from the axle sensors.

\subsection{REDMOND SITE}

As previously mentioned, completion of the installation of the instruments at the Redmond did not occur until August 23, 2008. Completion of the wiring of the instruments to the data acquisition systems occurred on September 25, 2008. Data were also collected during this visit. Hence, only one data collection effort occurred at the Redmond site prior to the end of the contract for this project. 


\subsection{DATA REDUCTION AND ANALYSIS}

Voltages were collected from the strain gages using the StrainBook requiring conversion to engineering units of strain, whereas WIM data required adjustment to long-term averages derived from weigh stations. This section summarizes the methodologies utilized for reducing the strain data and adjusting the WIM data.

\subsection{STRAIN DATA}

Figure 5.1 illustrates a typical set of data obtained from three longitudinal strain gages (AB01, AB02, and AB03) from the I-5 test site. The chart shows gage response in millivolts plotted against time in milliseconds. The gage responses due to individual axle loads (i.e., steering axle, drive axles, and trailer axles) were clearly evident from data obtained from the longitudinal gages but, in most cases, were not always readily evident from data obtained from the transverse gages as illustrated in Figure 5.2.

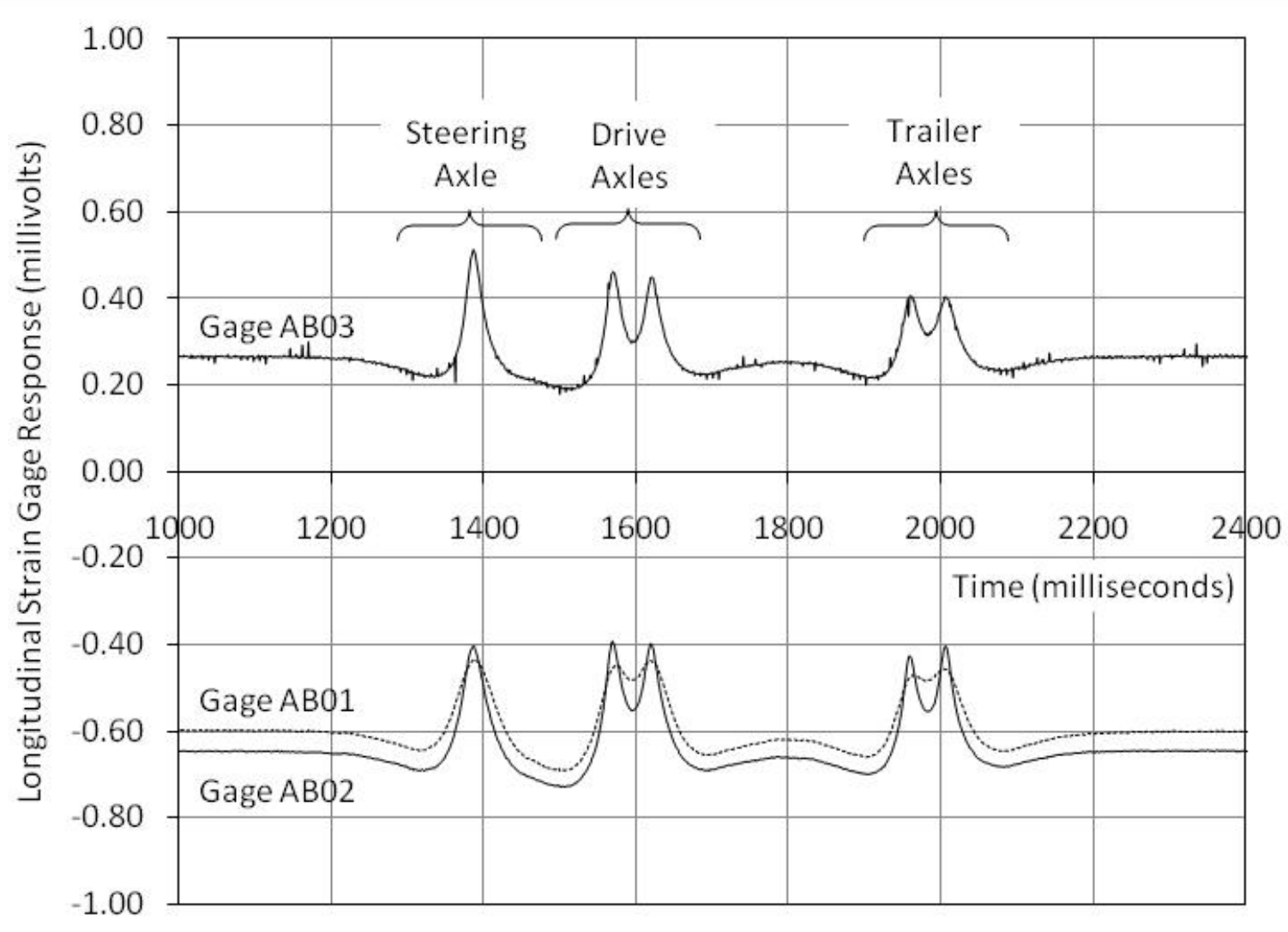

Figure 5.1: Typical set of data obtained from the longitudinal strain gages. 


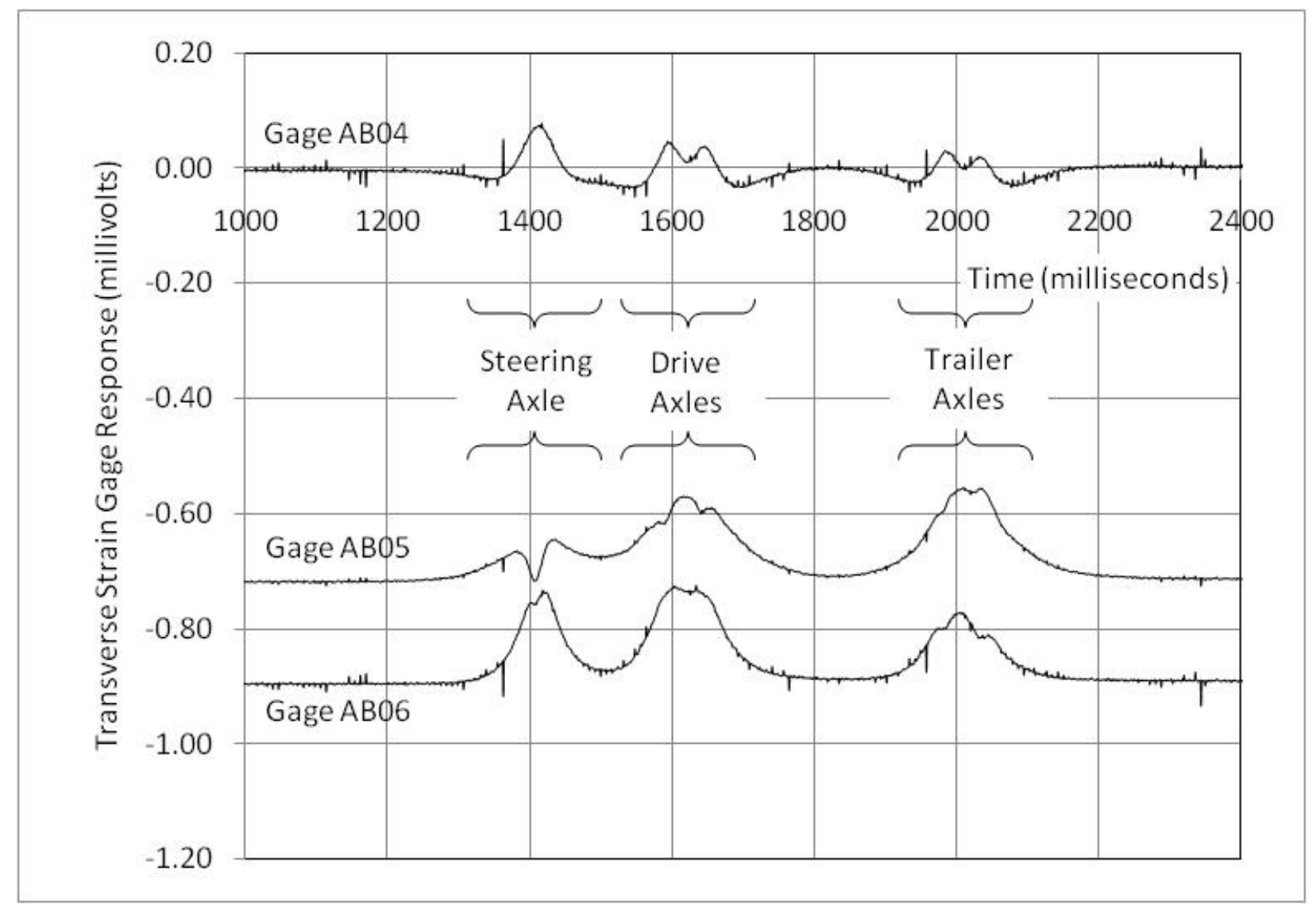

Figure 5.2: Typical set of data obtained from the transverse strain gages.

Reduction of the strain data entailed determining the differential voltage output from each strain gage caused by each individual axle load and multiplying these values by the calibration factors of the respective strain gages to provide the differential tensile strain responses. However, two slightly different approaches were utilized for reducing the data from the longitudinal and transverse gages.

Figure 5.3 shows typical responses of a longitudinal strain gage to a passing five-axle truck. It can be seen as the steering axle approached the location of the strain gage, the gage went into compression, and then into tension as the axle passed over the gage, and then into compression again as the axle retreated from the gage location. Further, it can be seen that the gage remained in compression until the first drive axle passed over the gage, but remained in tension between the drive axles. Similar observations can be about the response of the gage to the trailer axles.

For longitudinal strain gages, differential voltages due to tensile loads were determined by subtracting the minimum voltage value from the maximum voltage value as illustrated in Figure 5.3. It is important to note that the amount of tension required to overcome the compression was included as part of the total tensile strain imparted by a particular axle load. 


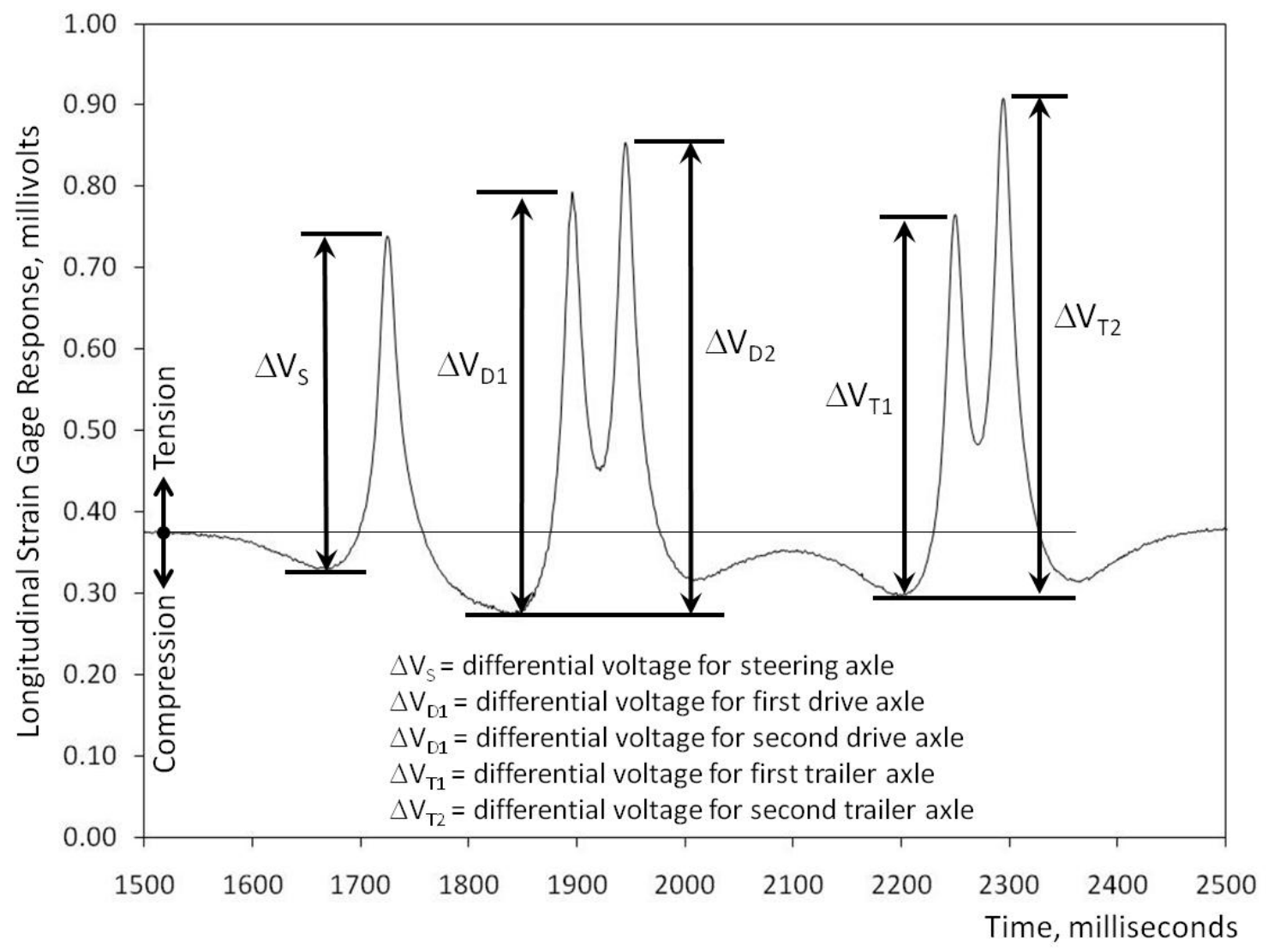

Figure 5.3: Methodology for reducing the longitudinal strain gage data.

Figure 5.4 shows typical "clean" responses of a transverse strain gage to the same five-axle truck. It should be noted that, in the majority of cases, the responses of the transverse gages were as shown in Figure 5.2. Nevertheless, it can be seen from Figure 5.4 that the transverse gage did not go into to compression. It can be further noted that the gage remained in tension throughout the time it took for the truck to pass over the gage. Indeed, this was true of the responses of every transverse strain gage to every passing axle load. Thus, for transverse strain gages, differential voltages due to tensile loads were determined by subtracting the quiescent voltage value from the maximum voltage value as illustrated in Figure 5.4.

The methodologies for reducing the strain data appear quite simple, but in reality reduction of the data required a substantial effort. The data were imported into a spreadsheet, categorized by strain gage type and location in the grid, and then plotted on graphs. Code was written to import and format the data and to aid in determining the maxima and minima of the voltage values. However, despite having a partially automated process, a significant amount of human interaction was required. A typical set of data from the I-5 site (with 24 gages) took approximately 45 minutes to reduce per truck. Due to the length of time required to reduce each data set, mostly due to human interaction, development of a LabView program to reduce the data more efficiently was initiated. However, it had not been completed prior to the end of this project. 


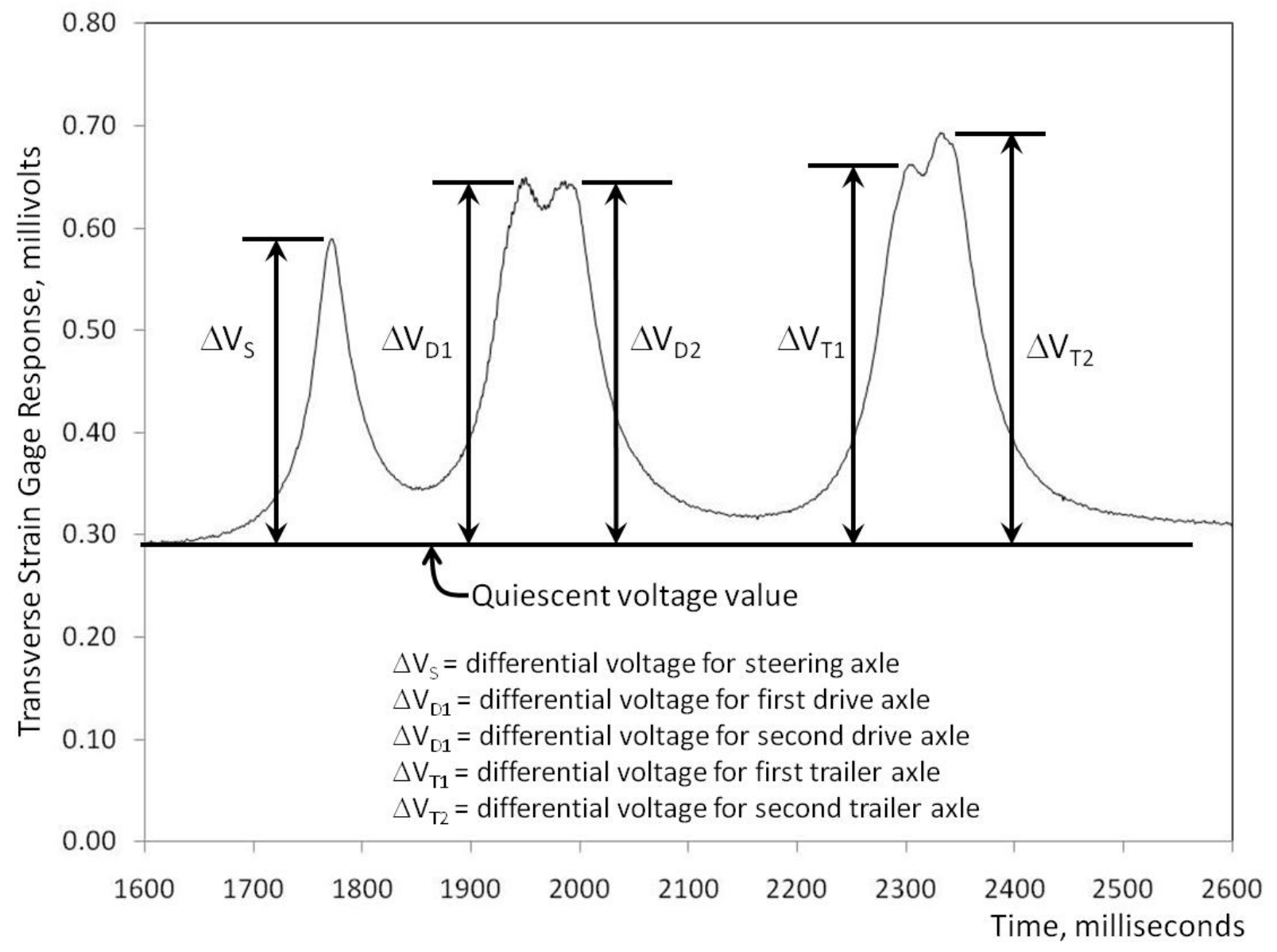

Figure 5.4: Methodology for reducing the transverse strain gage data.

Appendix B contains the reduced strain and WIM data for the data collected from the I-5 tests site on January 23, 2008. The data from the Redmond site was only partially reduced and thus has not been included.

\subsection{WIM DATA}

The WIM data acquisition system and software provided an electronic file that included, for each vehicle that crossed the WIM sensors, data and time, vehicle classification, gross vehicle weight, individual axle weights, distance between individual axles, total distance between the steering axle and last axle, and vehicle speed. Weights were corrected for temperature by the WIM software. However, the weights also required adjustment to known gross vehicle and axle weights obtained from weigh stations. 


\subsubsection{Gross Vehicle Weight Adjustment}

Individual gross vehicle weights obtained during a given site visit were adjusted to a long-term average gross vehicle weight $\left(\mathrm{GVW}_{\mathrm{LT} \text { Avg }}\right)$ obtained from the nearest weigh station. This was accomplished by calculating a correction factor $\left(\mathrm{CF}_{\mathrm{GVW}}\right)$ as shown in Equation 5.1 and applying it to individual unadjusted gross vehicle weights $\left(\mathrm{GVW}_{\text {Unadj }}\right)$ to determine the adjusted gross vehicle weights $\left(\mathrm{GVW}_{\mathrm{Adj}}\right)$ as shown in Equation 5.2.

$$
C F_{G V W}=\frac{G V W_{A v g}}{G V W_{L T A v g}}
$$

Where:

$$
\begin{aligned}
& \mathrm{CF}_{\mathrm{GVW}}=\quad \text { Gross vehicle weight correction factor } \\
& \mathrm{GVW}_{\text {Avg }}=\quad \text { Average of gross vehicle weights obtained during a given site visit } \\
& \mathrm{GVW}_{\text {LT Avg }}=\text { Long-term average gross vehicle weight obtained from nearest } \\
& \text { weigh station } \\
& G V W_{A d j}=\frac{G V W_{U n a d j}}{C F_{G V W}} \\
& \mathrm{GVW}_{\text {Adj }}=\text { Adjusted gross vehicle weight of an individual vehicle } \\
& \mathrm{GVW}_{\text {Unadj }}=\text { Unadjusted gross vehicle weight of an individual vehicle } \\
& \mathrm{CF}_{\mathrm{GVW}}=\quad \text { Gross vehicle weight correction factor (Equation 5.1) }
\end{aligned}
$$

\subsubsection{Axle Weight Adjustment}

Adjustment of the individual axle weights obtained during a given site visit required a three step process. Firstly, the average of the steering axles weights $\left(\mathrm{SAW}_{\mathrm{Avg}}\right)$ was multiplied by the gross vehicle weight correction factor $\left(\mathrm{CF}_{\mathrm{GVw}}\right)$ as shown in Equation 5.3 to determine the adjusted average steering axle weight $\left(\mathrm{SAW}_{\mathrm{Adj}}\right)$.

$$
S A W_{A d j}=S A W_{A v g} \times C F_{G V W}
$$

Where:

$\mathrm{SAW}_{\mathrm{Adj}}=\quad$ Average of steering axle weights obtained during a given site visit adjusted to the long-term average gross vehicle weight 


$$
\begin{array}{ll}
\mathrm{SAW}_{\mathrm{Avg}}= & \text { Average of steering axle weights obtained during a given site visit } \\
\mathrm{CF}_{\mathrm{GVW}}= & \text { Gross vehicle weight correction factor (Equation 5.1) }
\end{array}
$$

Secondly, the axle weight correction factor ( $\left.\mathrm{CF}_{\text {Axle }}\right)$ was determined by dividing the adjusted average steering axle weight (Equation 5.3) by the long-term average steering axle weight $\left(\mathrm{SAW}_{\mathrm{LT} \mathrm{Avg}}\right)$ obtained from the nearest weigh station as shown in Equation 5.4.

$$
C F_{A x l e}=\frac{S A W_{A d j}}{S A W_{L T} A v g}
$$

Where:

$$
\begin{aligned}
& \mathrm{CF}_{\text {Axle }}=\quad \text { Axle weight correction factor } \\
& \mathrm{SAW}_{\mathrm{Adj}}=\quad \text { Average of steering axle weights obtained during a given site visit } \\
& \text { adjusted to the long-term average gross vehicle weight } \\
& \mathrm{SAW}_{\text {LT Avg }}=\text { Long-term average steering axle weight obtained from nearest } \\
& \text { weigh station }
\end{aligned}
$$

Finally, the adjusted individual axle weights $\left(\mathrm{AW}_{\mathrm{Adj}}\right)$ were determined by multiplying the unadjusted axle weights ( $\left.\mathrm{AW}_{\text {Unadj }}\right)$ by the axle weight correction factor $\left(\mathrm{CF}_{\mathrm{Axle}}\right)$ as shown in Equation 5.5.

$$
A W_{\text {Adj }}=\frac{A W_{\text {Unadj }}}{C F_{\text {Axle }}}
$$

Where:

$$
\begin{aligned}
& \mathrm{AW}_{\mathrm{Adj}}=\text { Adjusted weight of an individual axle on an individual vehicle } \\
& \mathrm{AW}_{\text {Unadj }}=\text { Unadjusted weight of an individual axle on an individual vehicle } \\
& \mathrm{CF}_{\text {Axle }}=\text { Axle vehicle weight correction factor (Equation 5.4) }
\end{aligned}
$$

\subsection{TRUCK POSITION}

Although the axle sensors were installed at both test sites to determine the lateral (transverse) position of the trucks in the travel lane, the circuitry and data acquisition methodology were under development. This was completed during the latter part of the year and first fully implemented during the first data collection effort at the Redmond site. 
While the methodology was being developed, the truck position at the I-5 site was determined by taking photos of the trucks from the overpass and scaling off its position. Figure 5.5 illustrates a typical photo and method of determining its position within the lane. The lane width was physically measured in the field to be 12.0 feet from the outside edge of the fog line to the outside edge of the skip stripe. Using this as a reference, the length of the horizontal line indicating the lane width on the photo was used to establish the scale of the photo. The horizontal length of any other line on the photo was then compared with the lane width line to determine its actual length in the field. It should be noted that, although the horizontal lines are separated vertically on the photo, they were drawn at the same vertical location as the lane width line to eliminate error due to the photo having a vanishing point, and then moved to the vertical position shown on the photo.

Information in addition to the truck position was also determined from the photos for use in analyses. These included width of single tire treads, the dual tire width (outside of tread to outside of tread), and the axle width (also outside of tread to outside of tread). Analyses of photos of approximately 150 trucks were used to obtain average values for use in further analyses.

The results from the photos were also used to verify the position of the truck derived from the axle sensors. This was only performed at the I-5 site because there was no practical way to photograph trucks at the Redmond site.

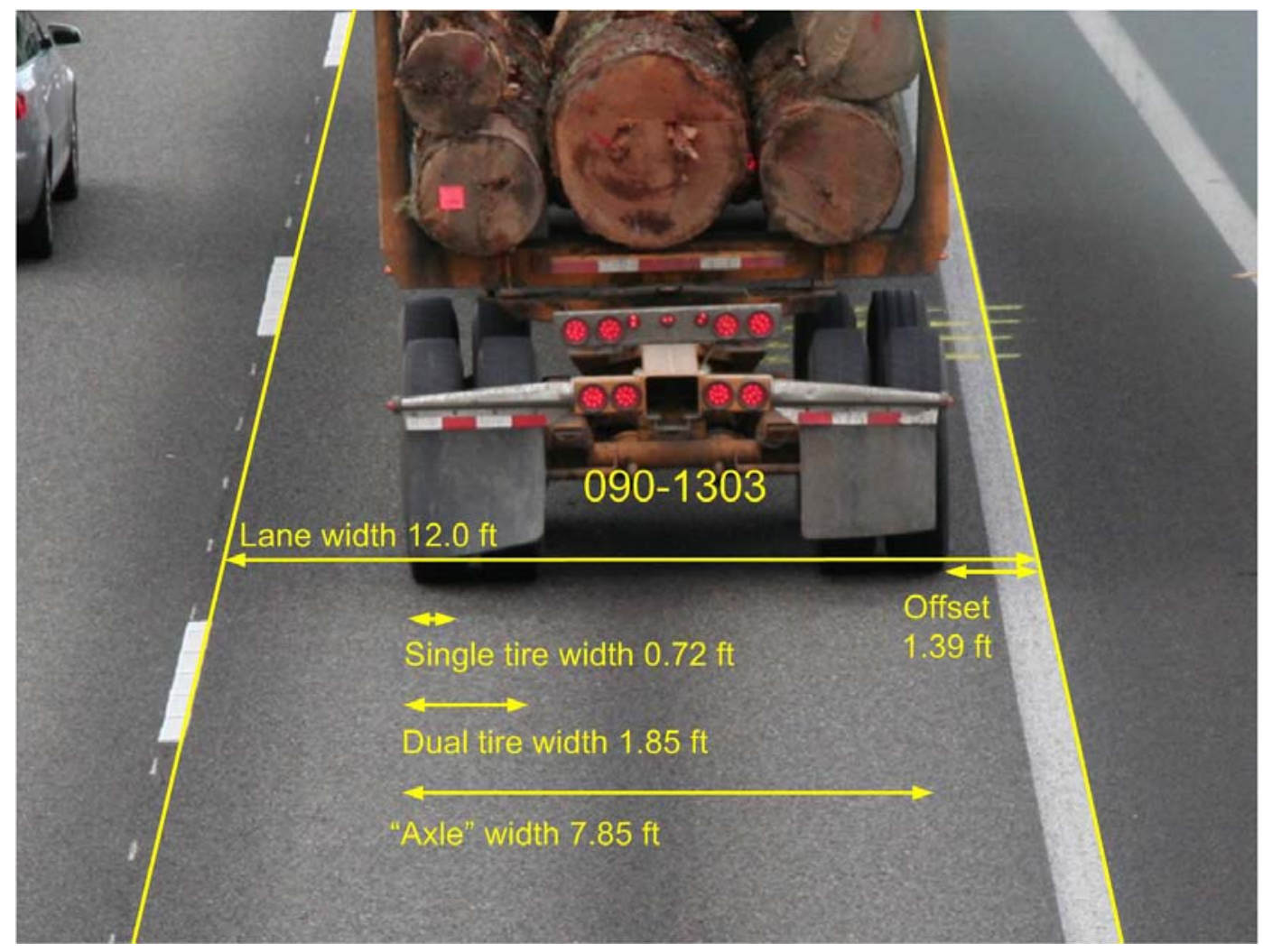

Figure 5.5: Photographic method of determining truck position. 
Utilizing the axle sensors to determine truck position entailed obtaining the time stamps of an axle passing over the three sensors. Section 3.4 described the theory for determining the truck position utilizing this information and knowing the geometry of the axle sensors. The signals from the axle sensors were similar to those obtained from the strain gages. The time stamps were determined from the point in time that the axle sensor signals reached a peak. Only the signals from the steering axles of trucks were used to determine the lateral (transverse) position of the trucks.

\subsection{ANALYSIS}

Table 5.1 shows an example of the measured (reduced) strain data induced by individual axle loads from a five-axle truck. The data were obtained from the I-5 test site. The data under the column headings labeled AB01 through AB12 represent responses of the gages placed over the aggregate base, whereas those under the column headings labeled RB01 through RB12 represent responses of the gages placed over the rubblized concrete base. Also included in the table are the adjusted weights of the individual axles. As indicated, several cells do not contain data, principally due to significant difficulties in interpreting the data (see, for example, Figure 5.2). In addition, one gage over the rubblized base (RB10) was not responding.

Table 5.1: Measured tensile strain induced by the axle loads of a five-axle truck (I-5 site).

HMA over Aggregate Base

\begin{tabular}{|c|c|c|c|c|c|c|c|c|c|c|c|c|c|}
\hline \multirow[b]{2}{*}{ Axle } & \multirow{2}{*}{$\begin{array}{c}\text { Axle Weight, } \\
\text { kips }\end{array}$} & \multicolumn{12}{|c|}{ Strain, microstrain } \\
\hline & & AB01 & ABO2 & $\mathrm{ABO} 3$ & $\mathrm{ABO4}$ & AB05 & $\mathrm{ABO6}$ & AB07 & ABO8 & ABO9 & $A B 10$ & $A B 11$ & $\mathrm{AB} 12$ \\
\hline S & 12.9 & 12.2 & 20.9 & 14.0 & * & 14.1 & $*$ & * & 14.8 & * & 13.3 & 24.2 & 15.0 \\
\hline D1 & 17.6 & 14.7 & 20.9 & 15.5 & * & 14.5 & $*$ & * & 14.1 & * & 15.2 & 23.1 & 15.0 \\
\hline $\mathrm{D} 2$ & 17.7 & 16.7 & 24.1 & 18.0 & * & 14.4 & * & * & 14.7 & * & 17.2 & 25.5 & 16.9 \\
\hline T1 & 19.2 & 13.8 & 20.6 & 13.5 & $*$ & 14.2 & * & $*$ & 14.5 & $*$ & 14.3 & 22.4 & 14.8 \\
\hline $\mathrm{T} 2$ & 18.2 & 14.3 & 21.4 & 15.4 & * & 13.6 & * & * & 14.1 & * & 14.0 & 22.2 & 15.9 \\
\hline
\end{tabular}

HMA over Rubblized PCC Base

\begin{tabular}{|c|c|c|c|c|c|c|c|c|c|c|c|c|c|}
\hline \multirow[b]{2}{*}{ Axle } & \multirow{2}{*}{$\begin{array}{c}\text { Axle Weight, } \\
\text { kips }\end{array}$} & \multicolumn{12}{|c|}{ Strain, microstrain } \\
\hline & & RB01 & RBO2 & RBO3 & RBO4 & RB05 & RB06 & RB07 & RBO8 & RBO9 & RB10 & RB11 & RB12 \\
\hline$S$ & 12.9 & * & 10.9 & 7.6 & 2.7 & 5.0 & * & 2.9 & 4.1 & * & $* *$ & * & 6.3 \\
\hline D1 & 17.6 & $*$ & 10.2 & 6.1 & 2.4 & 6.8 & * & 3.1 & 6.1 & * & $* *$ & * & 6.4 \\
\hline D2 & 17.7 & * & 11.8 & 7.8 & 2.6 & 7.5 & * & 3.1 & 6.7 & * & ** & * & 6.6 \\
\hline T1 & 19.2 & * & 10.3 & 6.4 & 2.2 & 6.6 & * & 3.1 & 6.2 & * & $* *$ & * & 6.4 \\
\hline $\mathrm{T} 2$ & 18.2 & * & 11.7 & 8.6 & 2.7 & 6.0 & $*$ & 3.1 & 5.2 & * & ** & * & 7.0 \\
\hline
\end{tabular}

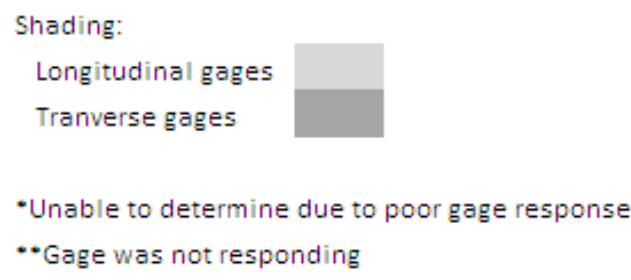

Shading:

Longitudinal gages

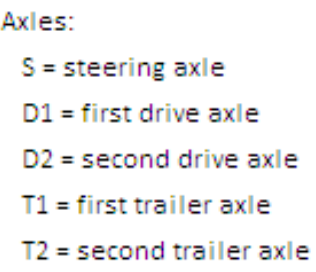


To satisfy one of the objectives of the study, the measured strain values were to be compared with predicted strain values obtained from the JULEA layered elastic analysis software program originally developed by Jacob Uzan of Technion - Israel Institute of Technology. Figure 5.6 shows the user interface for a Windows version of the JULEA software developed by the Waterways Experiment Station (WES) of the Engineer Research and Development Center (ERDC) of the U.S. Army Corps of Engineers.

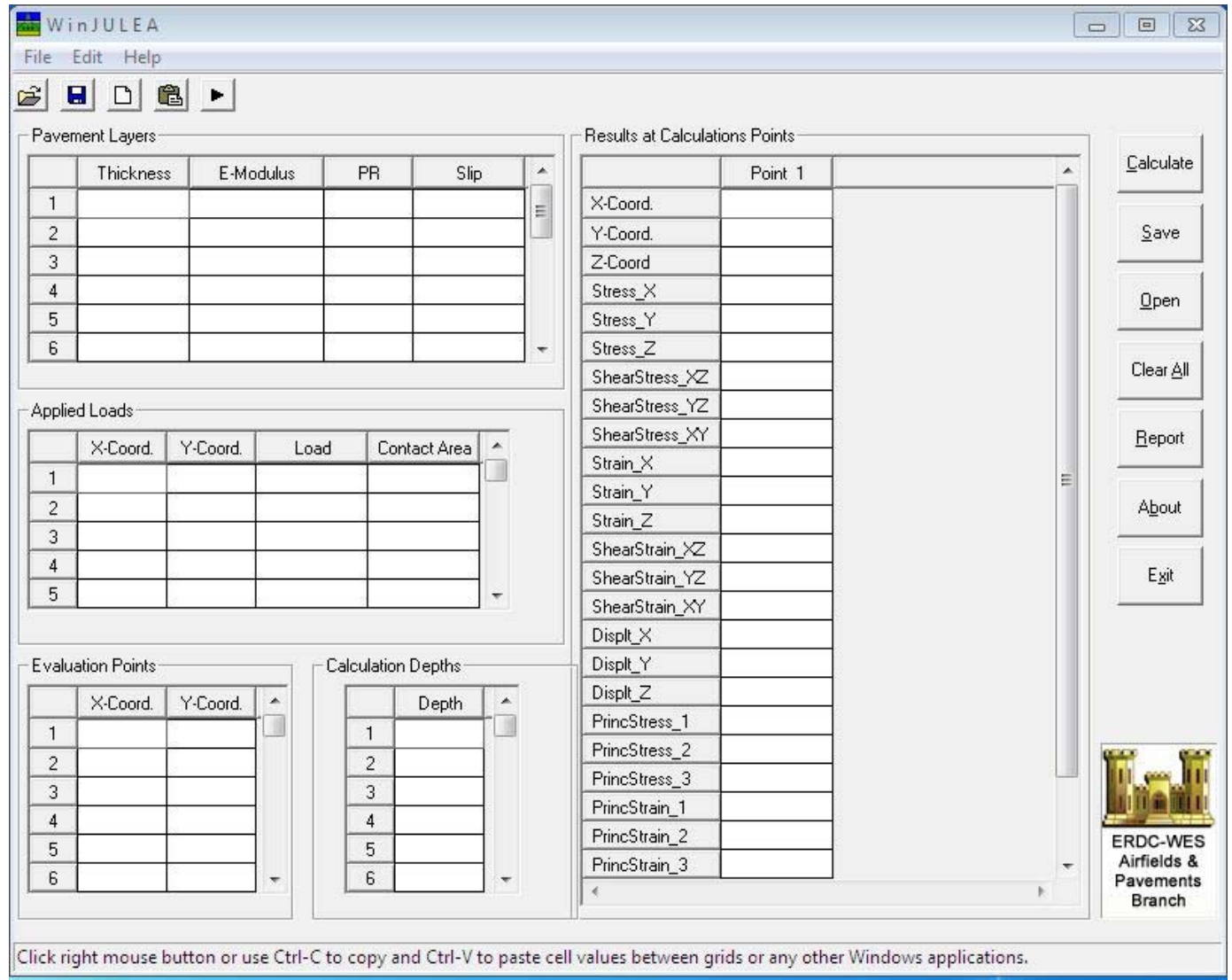

Figure 5.6: Windows version of JULEA developed by USACE ERDC-WES.

Pavement layer properties are entered in the top left ("Pavement Layers") grid of the application. These include the thickness, dynamic modulus ("E-Modulus"), and Poisson's ratio ("PR") for each layer of the pavement structure as well as the interface conditions ("Slip") between layers. The "Applied Loads" grid is where the coordinates, load, and contact area of each tire load are entered. Points of interest within the pavement structure for which the program calculates stresses and strains are entered in the "Evaluation Points" and "Calculation Depths" grids. Results are displayed in the grid on the right side of the user interface.

All information except the dynamic moduli and Poisson's ratios of the pavement layers and the tire contact areas has been determined for both tests sites. Without these parameters, final analyses could not be completed. Hence, predicted values of strain were not determined by the end of the contract period and, thus, were not compared with the measured values. 


\subsection{CONCLUSIONS AND RECOMMENDATIONS}

\subsection{CONCLUSIONS}

This report documents progress made toward satisfying the principal objective of the project; that being to obtain key information to be used to assess the validity of predicted tensile strain via layered elastic analysis. To accomplish this, it was planned to instrument three new HMA pavements with differing structure and truck traffic volume, and constructed in regions with different climatic conditions. Several projects were identified for this purpose, but all but one were eliminated from further consideration due to factors such as significant duplication of the existing site on Interstate 5, insufficient truck traffic volume, non-representative sections at bridge approaches, and placing the strain gages within the HMA layers rather than at the underside of the HMA layers.

Nevertheless, a site along the US 97 bypass around downtown Redmond was successfully instrumented in the summer of 2008. Details of the process were documented in this report. Data were collected from this site only once before the end of the contract period. However, it was only partially reduced and, thus, was not included herein.

Several attempts were made to collect data from the existing test site along Interstate 5. However, due to equipment malfunctions, personnel turnover, and unavailability of qualified personnel, only one data collection effort was successful. These data were fully reduced and included herein. Lack of all information necessary to develop predicted values prevented a comparison between measured and predicted values.

Despite the difficulties encountered at the I-5 tests site and the lateness in developing the Redmond site, progress was made with regard to data collection efforts (i.e., development of new software utilizing LabView for this purpose). Progress was also made in that the truck positions derived from the axle sensors were verified with the truck positions derived from photographs. Development of enhanced data reduction tools utilizing LabView was also initiated to reduce the required amount of human interaction and, therefore, the time required to complete the process.

\subsection{RECOMMENDATIONS}

To satisfy to principal objective of the project, reduction of the data from the Redmond site needs to be completed and analyses of predicted versus measured values from both test sites need to be conducted. Hence, it is recommended that these tasks be completed.

It is further recommended that development of the data acquisition and reduction software be completed. The new data acquisition software will eliminate the need for the WaveView software, which was difficult to use. The new data reduction software will reduce the need for human interaction and, therefore, reduce the time required to reduce the data. 
Although a significant effort is required to establish a test site, it is recommended that at least one more site be instrumented. Given the difficulties in identifying candidate sites with attributes significantly different from those already established, it is recommended that one of those identified herein be reconsidered for this purpose. 


\subsection{REFERENCES}

Timm D.H. and Priest, A.L., "Wheel Wander at the NCAT Test Track,” NCAT Report 05-02, National Center for Asphalt Technology, Auburn University, April 2005. 


\section{APPENDIX A}

\section{I-5 TEST SITE}


The test site on Interstate 5 was located just north of Albany as indicated in Figure 1. This part of the interstate is in the Willamette Valley bordered by the Coast Mountain Range to the West and Cascade Mountain Range to the East; hence, the test site is located in the intermountain climatic region on the west side of the state.

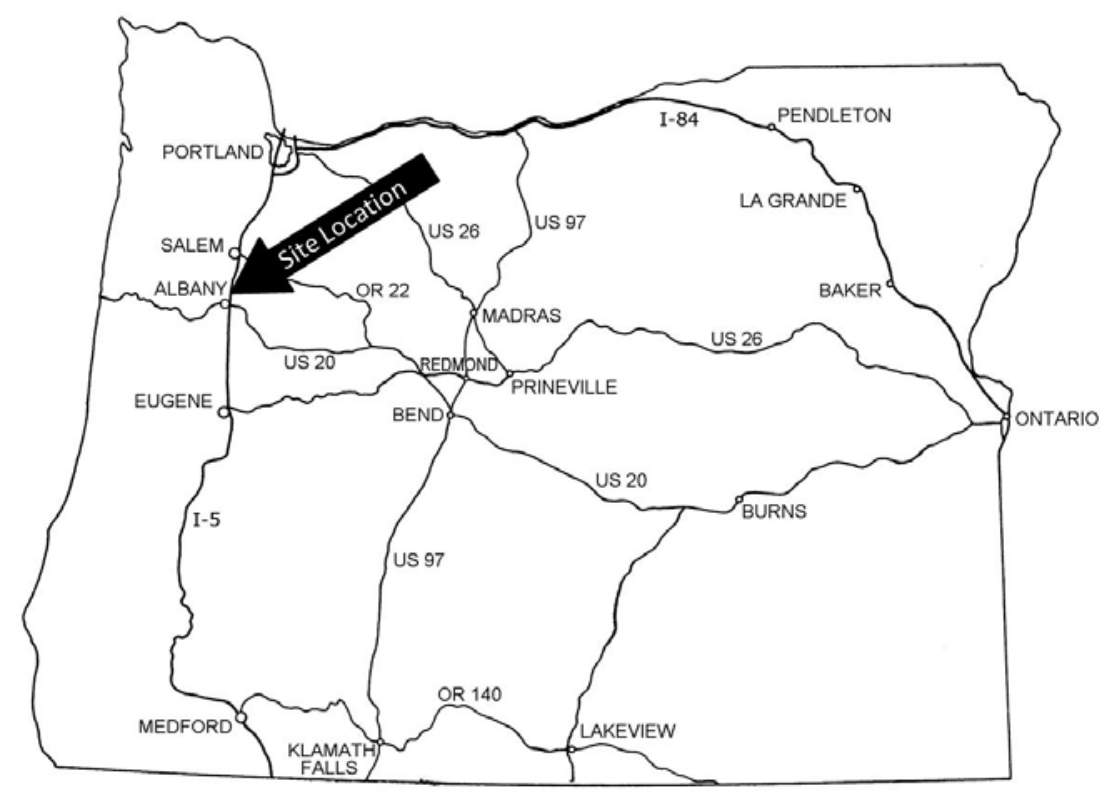

Figure 1: Test site on Interstate 5.

The test site was located in the southbound lanes immediately downstream of the Dever-Conner interchange near Mile Point 239 as illustrated in Figure 2. The majority of the construction project involved placing a hot-mix asphalt (HMA) overlay over rubblized jointed, reinforced concrete pavement (referred to as Rubblized JRCP Base in Figure 2). To maintain minimum clearance under structures (overpasses), the existing concrete pavement was removed and the pavement structure was reconstructed with aggregate base (referred to as Aggregate Base in Figure 2). Hence, the test site offered two pavement structures in one location. Figure 3 illustrates the two pavement structures at the I-5 test site, both designed for very heavy truck traffic. 


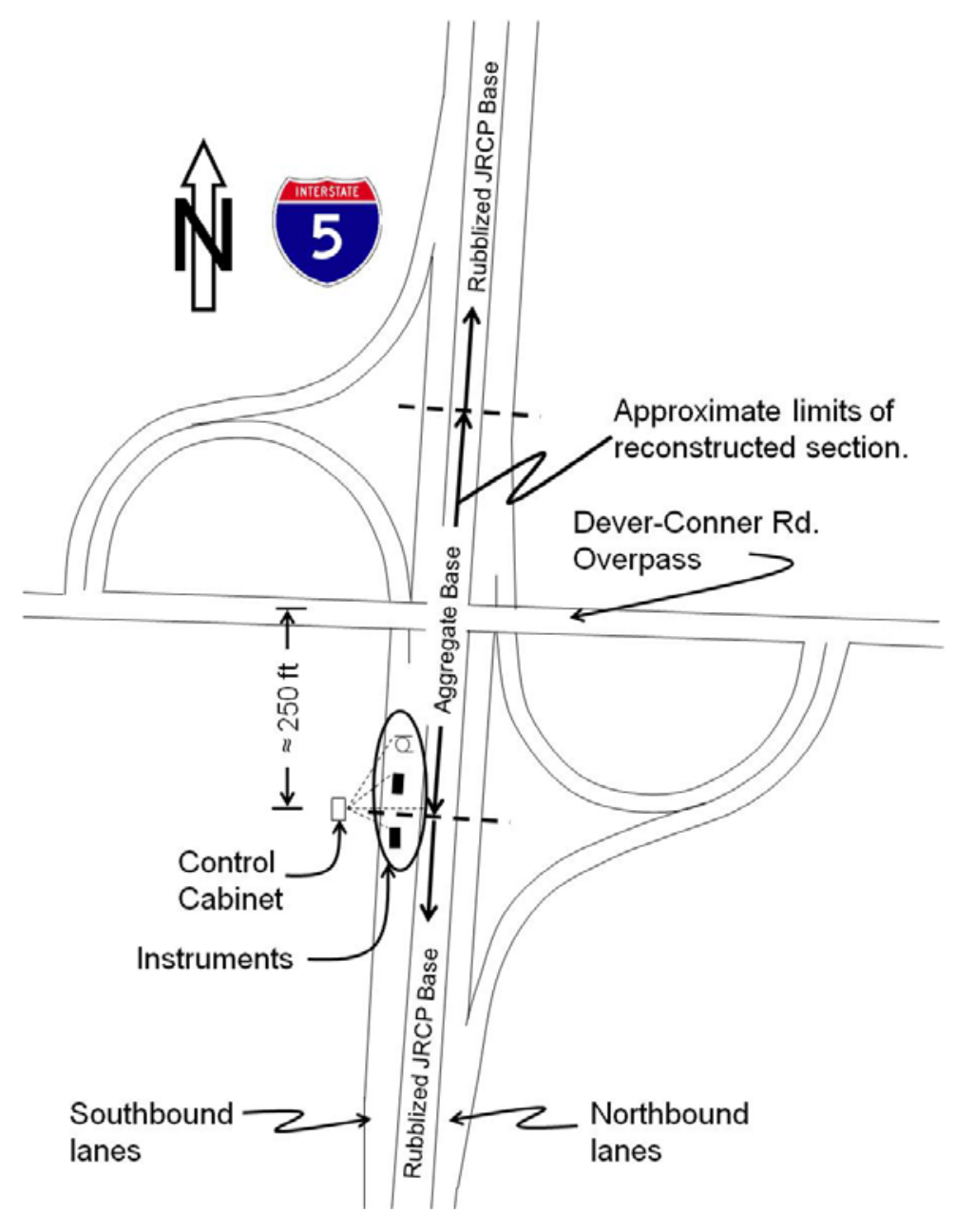

Figure 2: I-5 test site location at the Dever-Conner Interchange at MP 239.

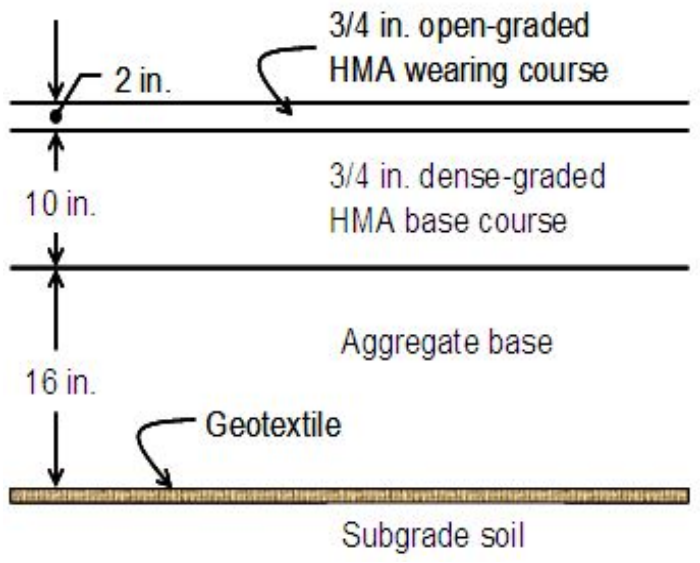

a) HMA over aggregate base

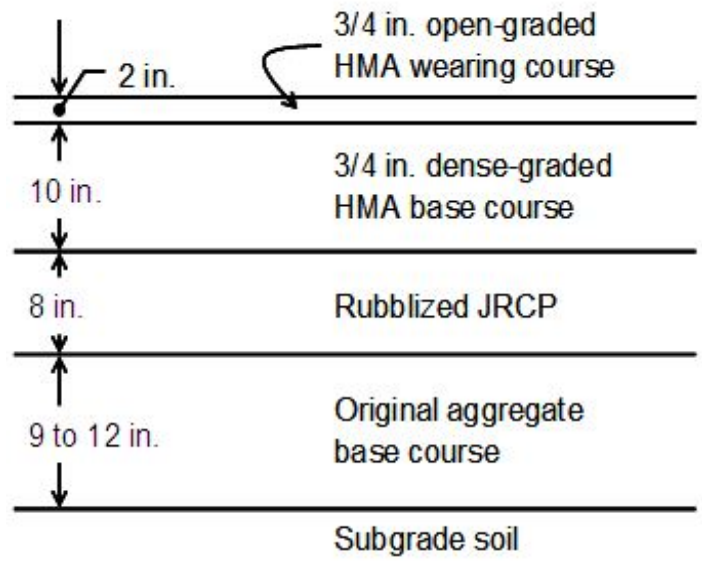

b) HMA over rubblized JRCP base

Figure 3: Pavement structures at the I-5 test site. 
CTL Group ASG-152 strain gages were placed on the surface of the aggregate base and rubblized JRCP base courses as shown in Figure 4. Each gage was tacked to a patty of a sand and emulsion mixture to protect them from damage during the placement and compaction of the overlying HMA layers.

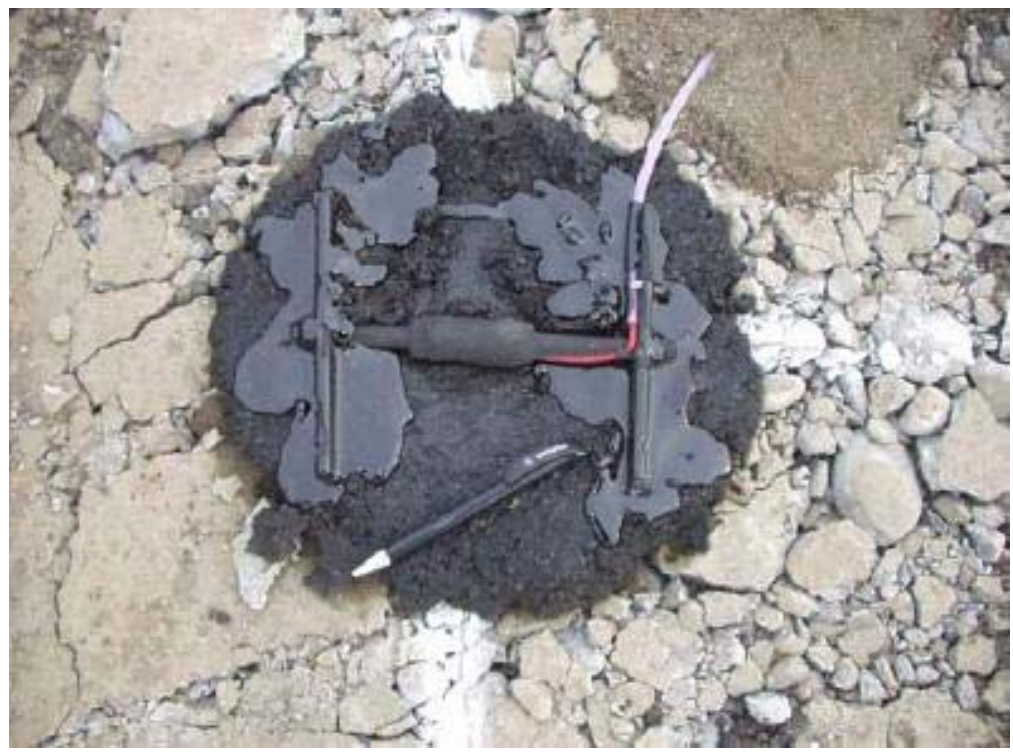

Figure 4: Close-up view of a strain gage over the rubblized JRCP base course at the I-5 site.

Figure 5 shows a picture of the strain gage array for the section with aggregate base indicating that the strain gages were arranged in an array of 12 gages, with six oriented to measure longitudinal strain and six to measure transverse strain, whereas Figure 6 illustrates the distances between gages for each section. The strain gage arrays were positioned to be directly beneath the outside wheel path of the outside (slow) lane.

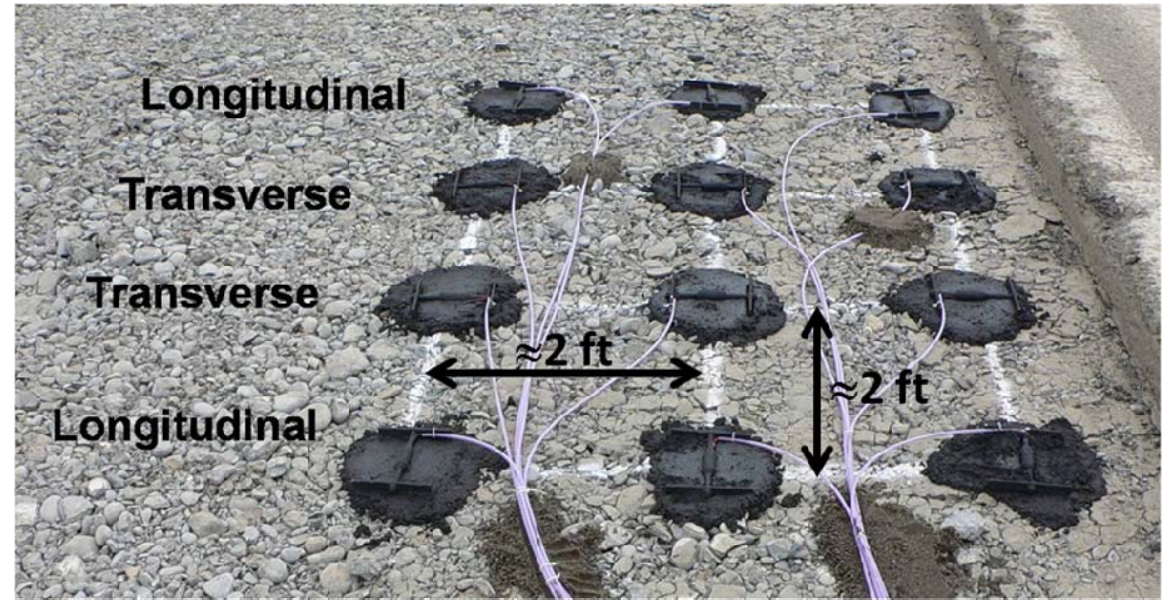

Figure 5: Strain gage array over the aggregate base course at the I-5 test site. 


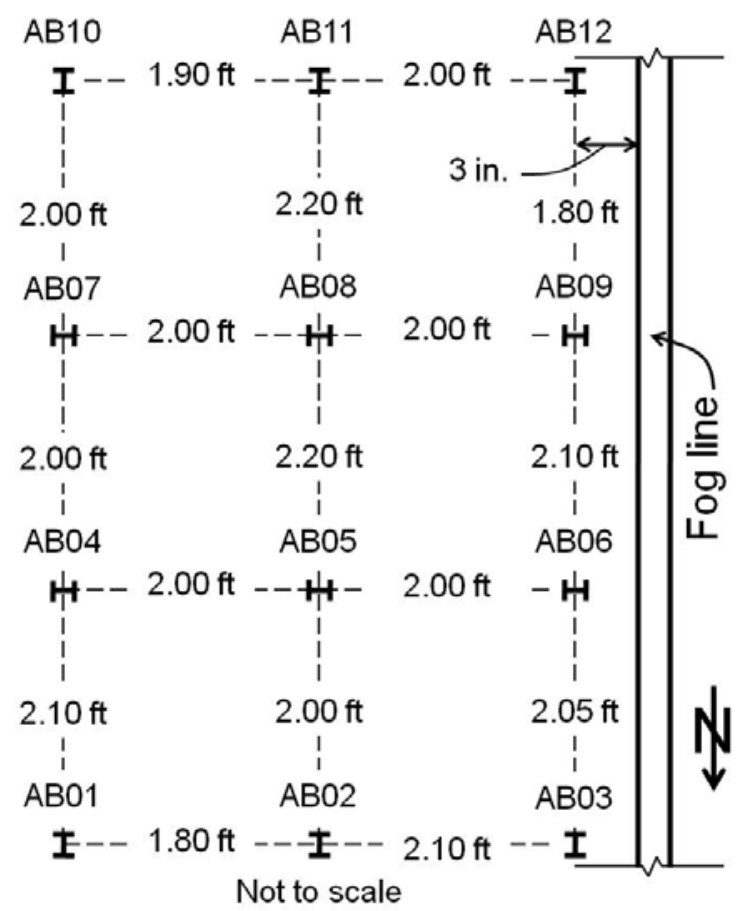

a) Strain gage array over aggregate base

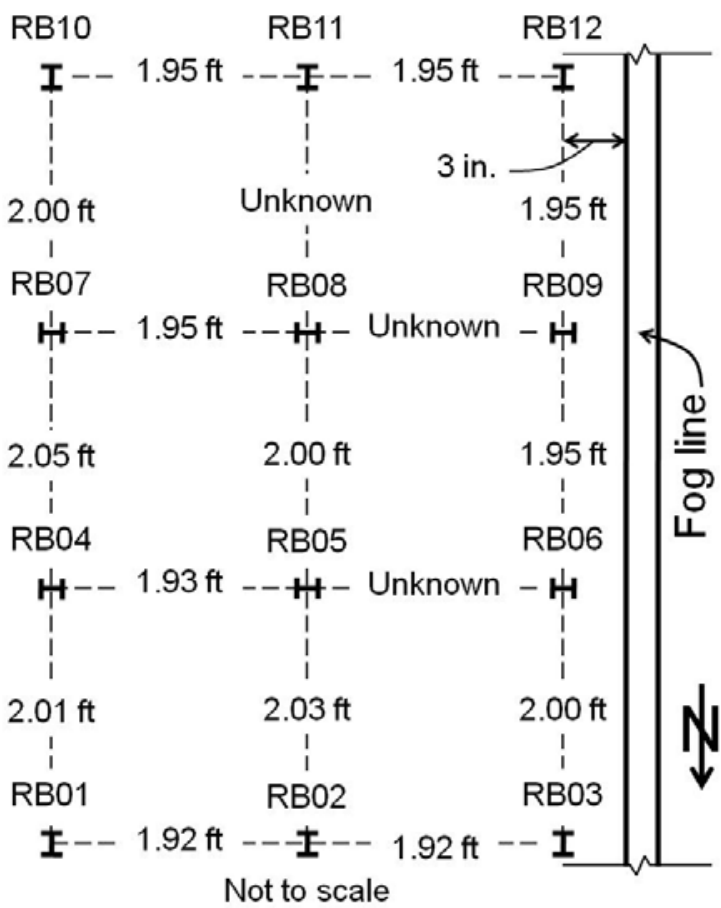

b) Strain gage array over rubblized JRCP

Figure 6: Distances between strain gages at the I-5 test site.

Figure 7 shows a picture of the I-5 test site taken from the Dever-Conner overpass. At the time of the strain gage installation, the first lift of HMA had been placed over the aggregate base section. Hence, a portion of the HMA was removed so that the strain gages could be placed directly on the aggregate base course. Figure 7 also indicates where the strain gages were placed over the rubblized JRCP base course, which had not yet received a lift of HMA.

Following arrangement of the strain gages in the array over the aggregate base, the strain gages were covered with HMA and compacted as shown in the sequence of photos in Figure 8. The gages were first given a protective covering of loose HMA, which was lightly compacted with a hand tamper as shown in Figure 8a. The cutout was then filled with HMA (Figure 8b), which was spread to uniform thickness (Figure 8c) and compacted using a small roller (Figure 8d). Once the cutout was filled, the second lift of HMA was paved (Figure 8e) and compacted (Figure 8f) using conventional paving and compaction equipment. 


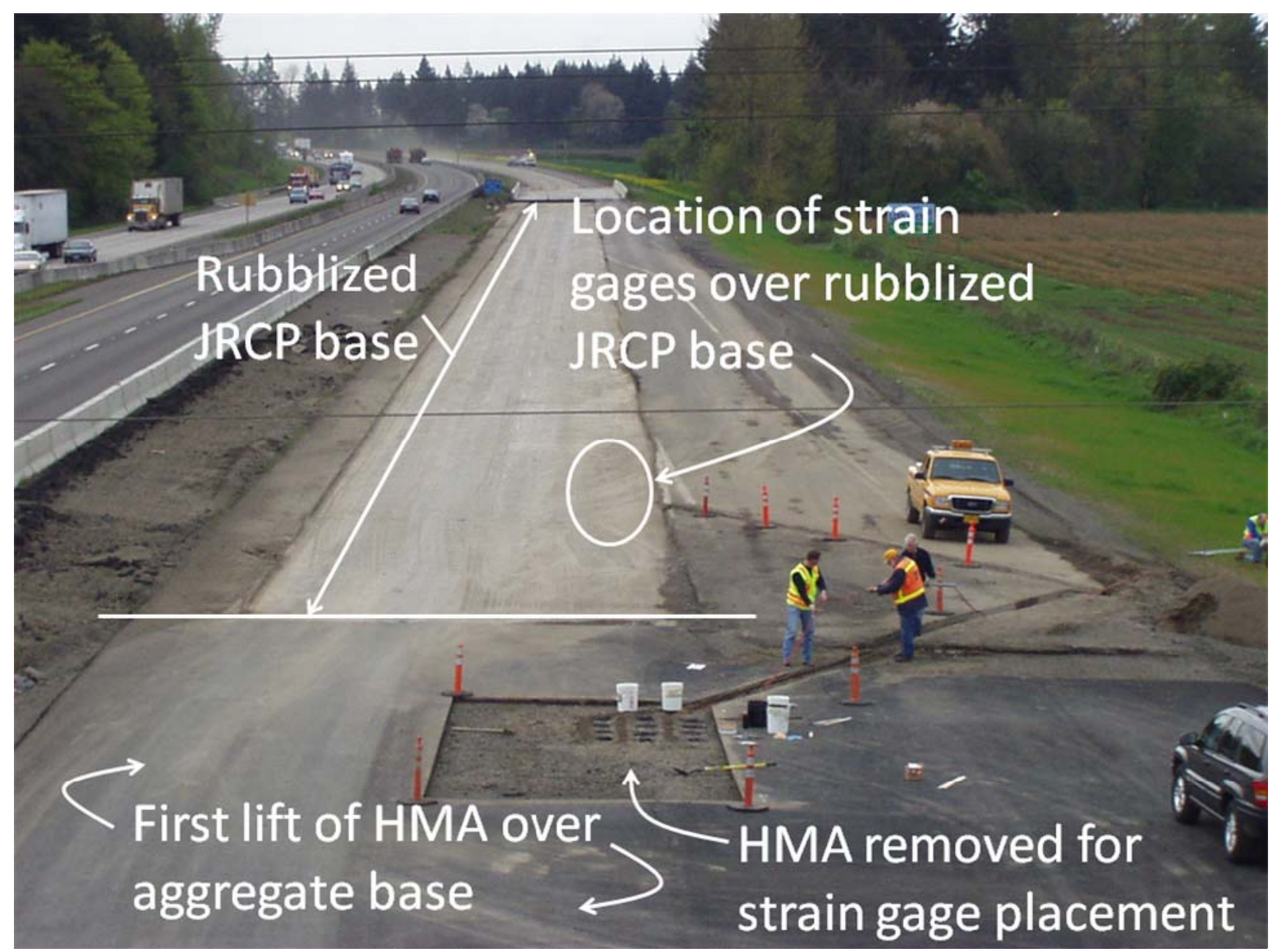

Figure 7: Overview of the I-5 test site during strain gage installation.

For the strain gages placed over the rubblized JRCP base course, the only difference in the construction sequence was that the first lift of HMA had not yet been placed, so a cutout was not necessary. In this case, prior to placement of the first lift of HMA, the strain gages were given a protective covering of HMA which was compacted using the small roller as shown in Figure 9.

Thermocouples were installed at various depths within the hot-mix asphalt layer following construction as illustrated in Figure 10. Installation occurred following construction and involved drilling holes to the appropriate depths, inserting the thermocouples, and filling the holes with epoxy. The thermocouples allowed monitoring of the HMA temperature with depth to an accuracy of at least $0.2^{\circ} \mathrm{F}\left(0.1^{\circ} \mathrm{C}\right)$. 


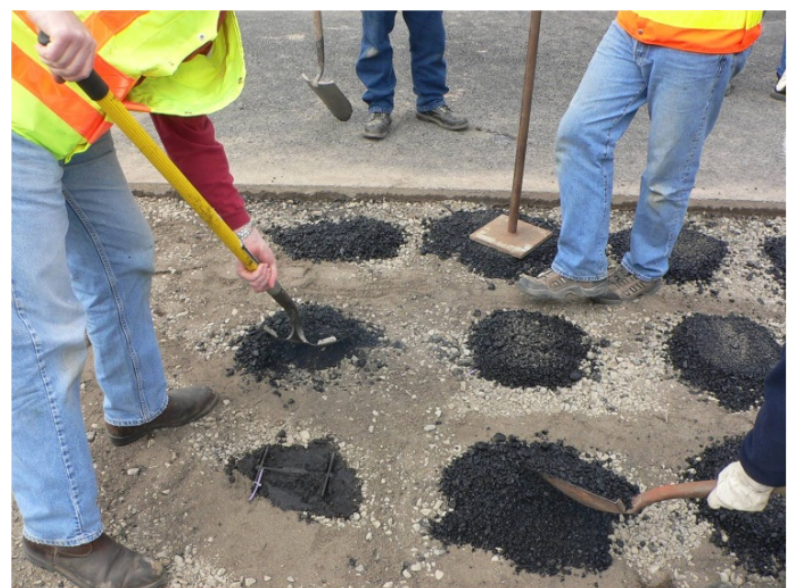

a) Protecting gages with loose HMA.

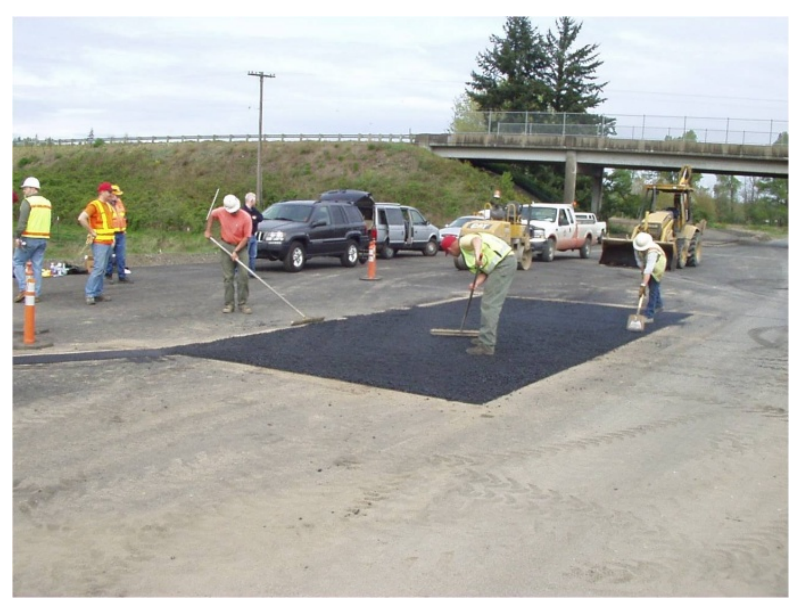

c) Spreading HMA over gages.

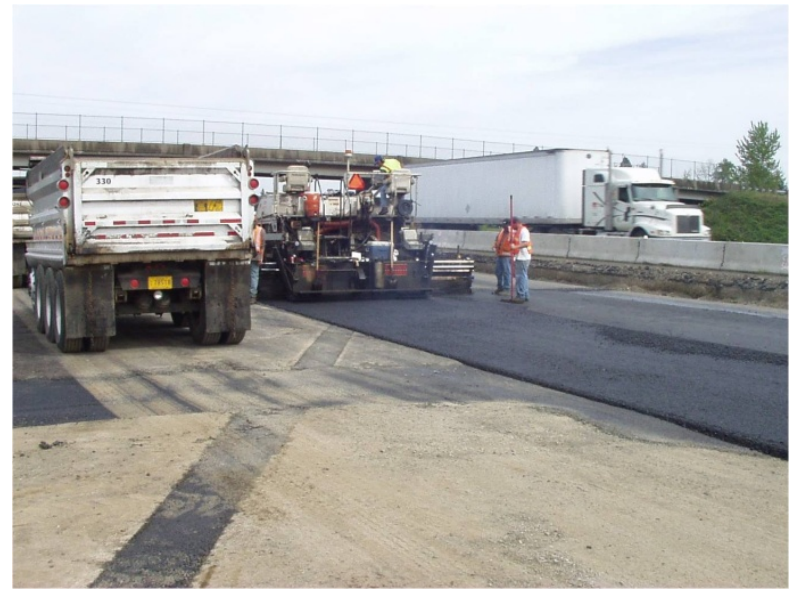

e) Paving second lift of HMA.

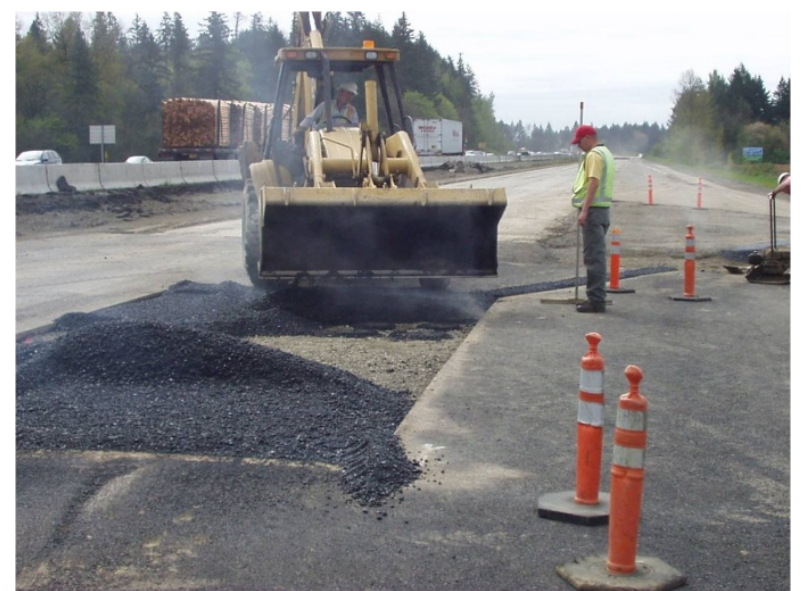

b) Covering gages with HMA.

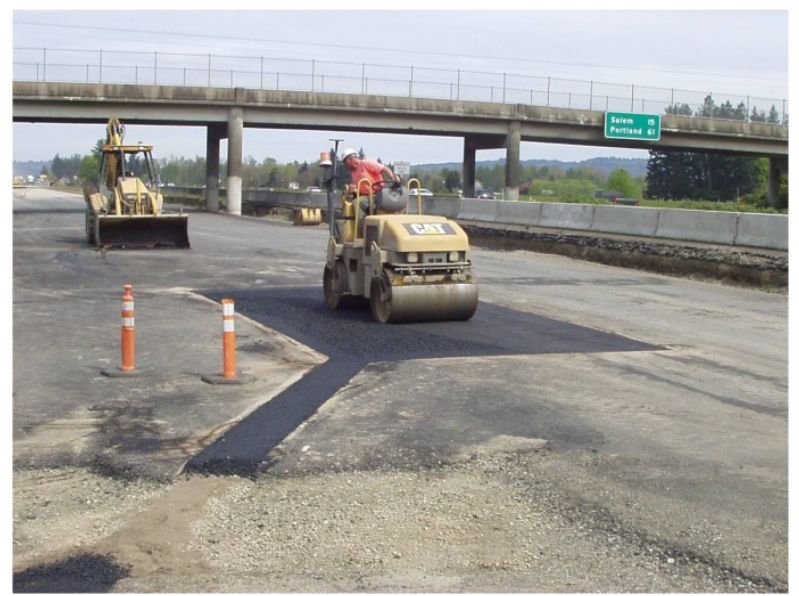

d) Compacting HMA with a small roller.

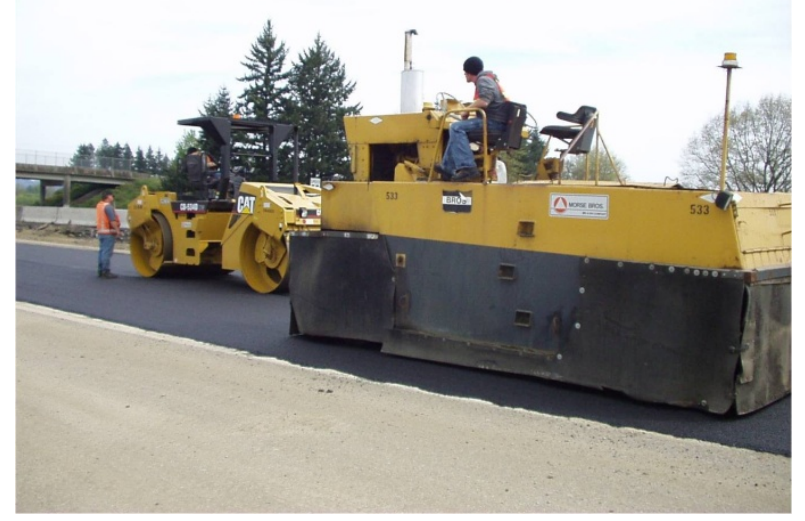

f) Compacting second lift of HMA.

Figure 8: Construction sequence to cover the strain gages over the aggregate base. 


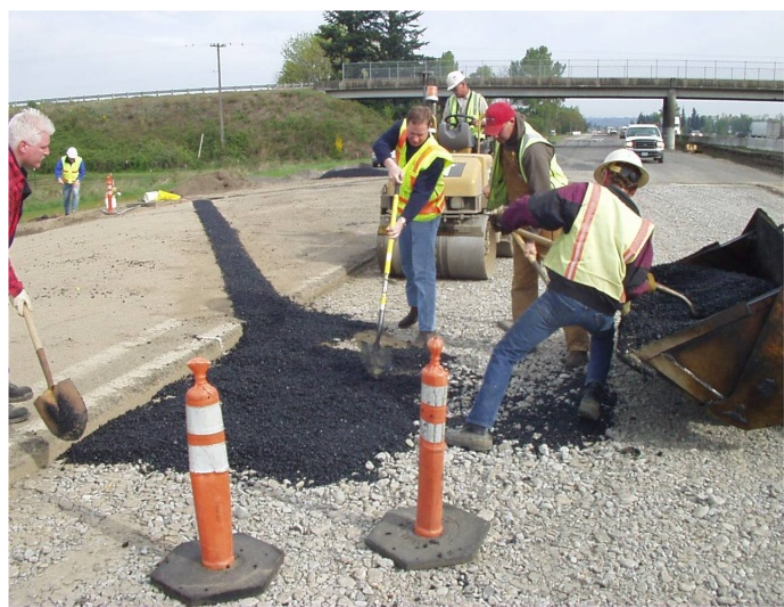

a) Covering gages with HMA.

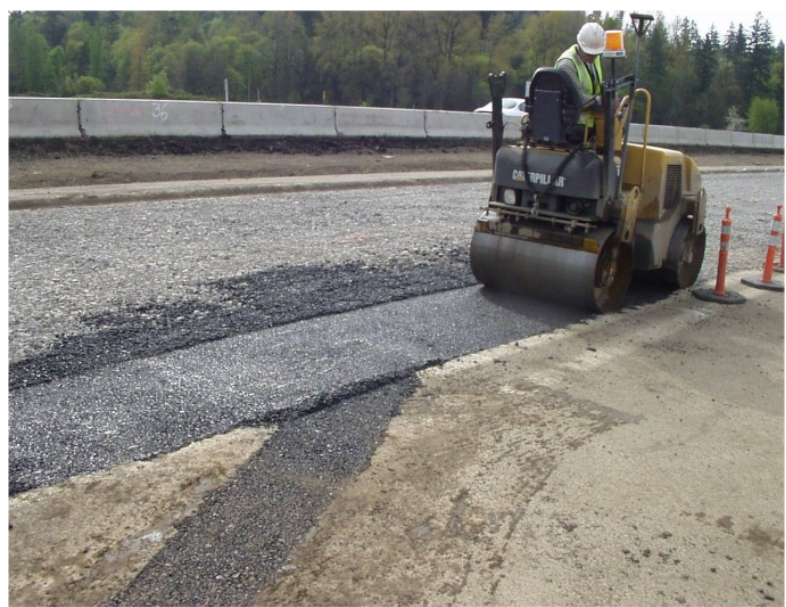

b) Compacting HMA with a small roller.

Figure 9: Partial construction sequence to cover the strain gages over the rubblized JRCP base.

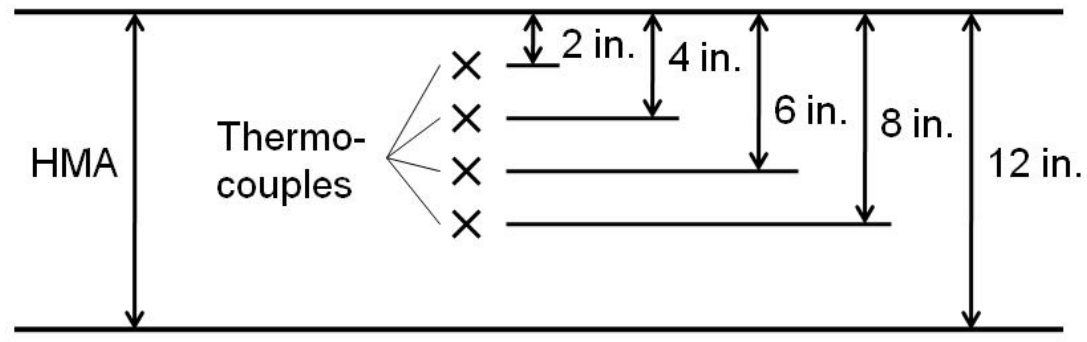

Figure 10: Depth of thermocouples installed in the HMA layer.

Weigh-in-motion (WIM) devices were installed on the surface of the HMA layer following construction. These included two piezoelectric strips and an induction loop as shown in Figure 11. A thermocouple was also installed under one of the piezoelectric strips (at 1 inch depth). The piezoelectric strips were used to measure axle loads of the vehicles crossing the strips, the induction loop was used to classify the vehicles, and the thermocouple was used to measure temperature. Installation involved cutting grooves in the surface of the pavement, cleaning and drying the grooves, placing the devices in the grooves, and filling the grooves with adhesiveepoxy for the piezoelectric strips and thermocouple and liquid asphalt for the induction loopsaround the devices. The WIM devices were installed upstream of the strain gages. 


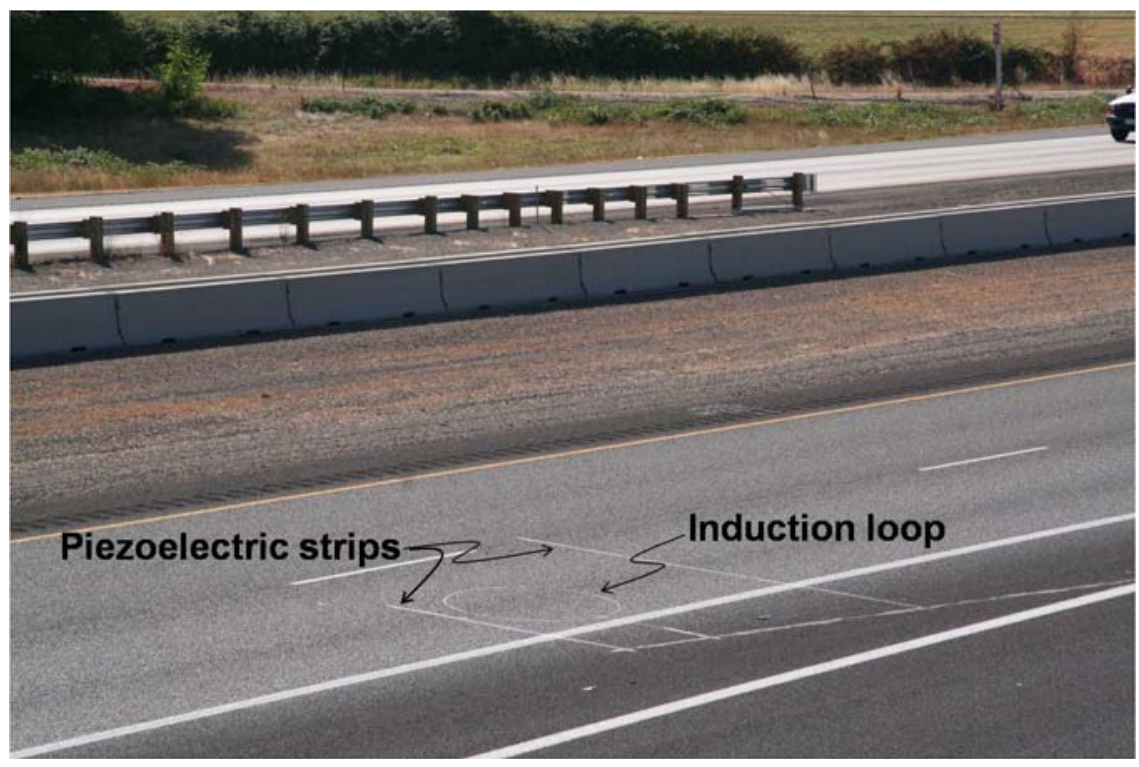

Figure 11: Weigh-in-motion (WIM) devices installed on the surface of the pavement.

Axle sensors were also installed on the surface of the pavement (Figure 12) following construction to determine the transverse position of vehicles in the travel lane. Installation involved cutting grooves in the surface of the pavement, cleaning and drying the grooves, placing the devices in the grooves, and filling the grooves with epoxy adhesive around the devices. Figure 13 illustrates the geometric layout of the axle sensors. Installation of the axle sensors was accomplished approximately 2 years after the strain gages were installed.

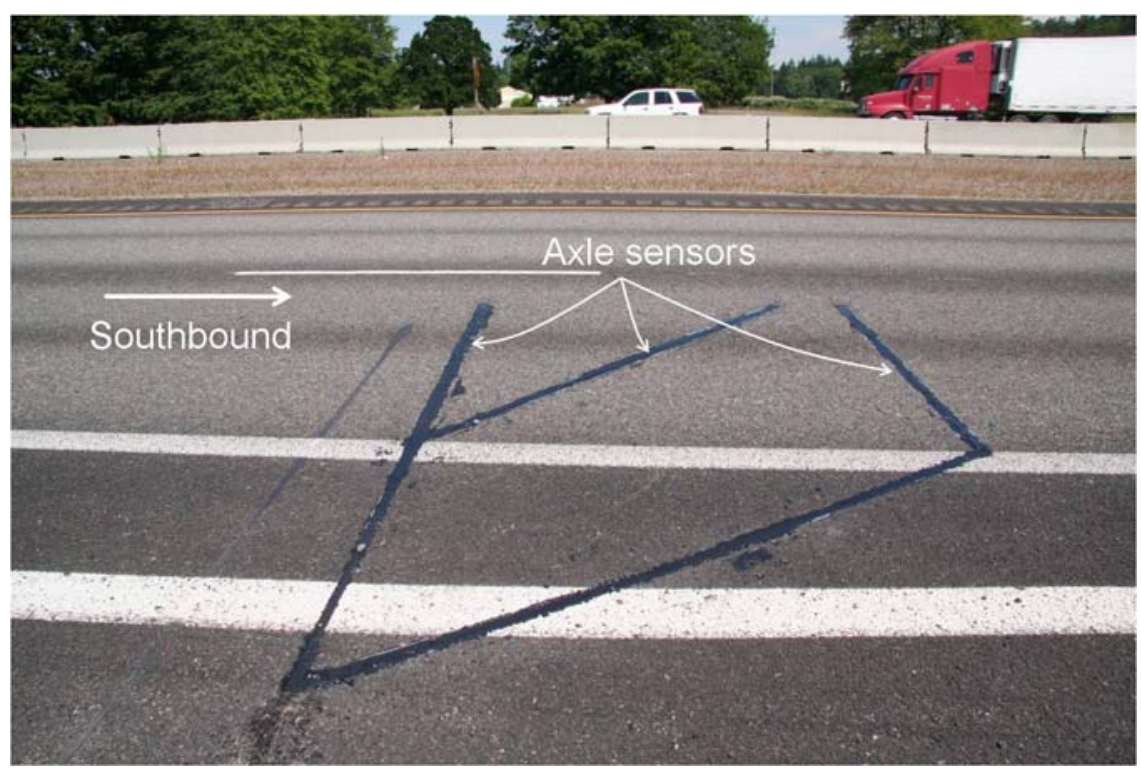

Figure 12: Axle sensors installed on the surface of the pavement. 


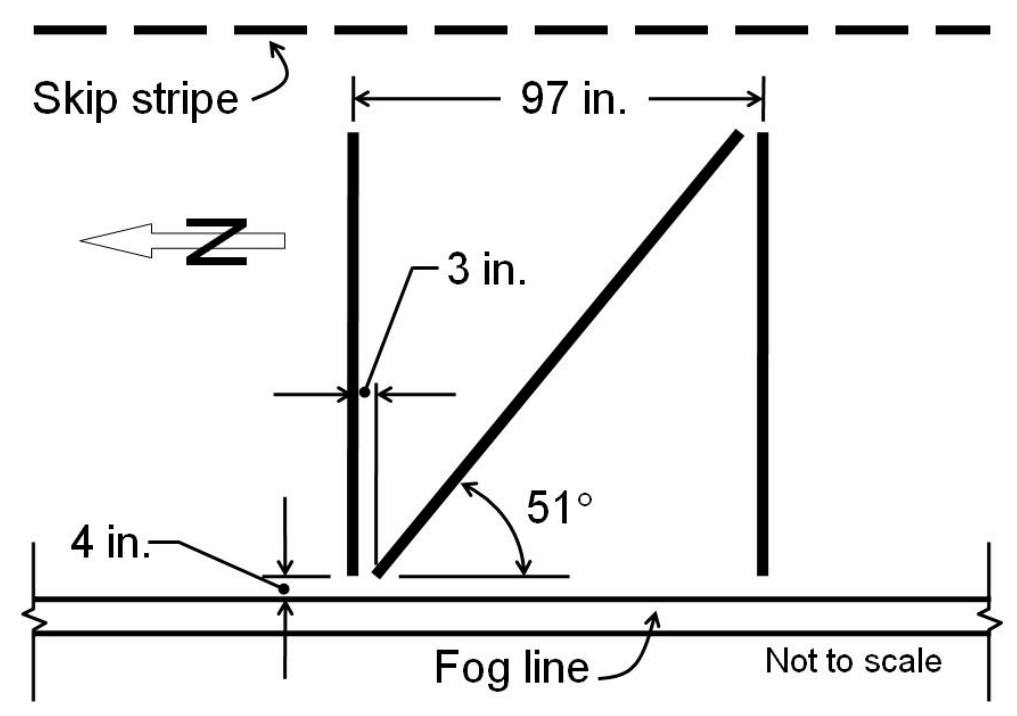

Figure 13: Geometric layout of the axle sensors.

An equipment cabinet (Figure 14) was installed at the site a safe distance from the highways (i.e., live traffic) to house the equipment necessary for data acquisition. Instrument cables (wires) were routed from the roadway to the equipment cabinet through a trench to prevent damage by traffic, weather, and maintenance equipment.

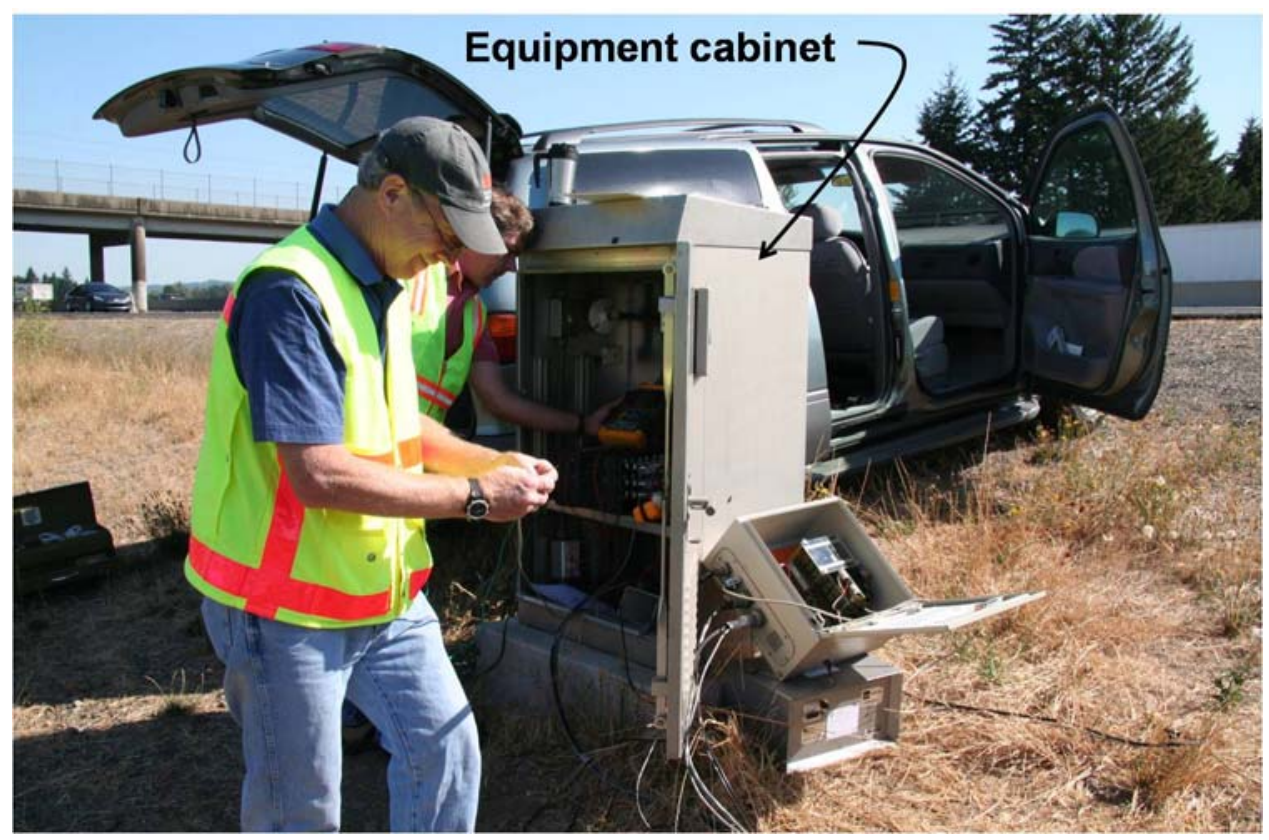

Figure 14: Equipment cabinet. 


\section{APPENDIX B}

\section{I-5 TEST SITE DATA (REDUCED)}


Date: 23-Jan-08 Strain Data File: 23Jan010.xlsx $\quad$ WIM VEN: 555

HMA over Aggregate Base

\begin{tabular}{|c|c|c|c|c|c|c|c|c|c|c|c|c|c|}
\hline \multirow[b]{2}{*}{ Axle } & \multirow{2}{*}{$\begin{array}{c}\text { Axle Weight, } \\
\text { kips }\end{array}$} & \multicolumn{12}{|c|}{ Strain, microstrain } \\
\hline & & AB01 & AB02 & $\mathrm{ABO3}$ & AB04 & AB05 & AB06 & AB07 & AB08 & ABO9 & AB10 & AB11 & AB12 \\
\hline $\mathrm{s}$ & 12.9 & 12.2 & 20.9 & 14.0 & * & 14.1 & $*$ & $*$ & 14.8 & * & 13.6 & 22.7 & 11.4 \\
\hline D1 & 17.6 & 14.7 & 20.9 & 15.5 & $*$ & 14.5 & * & $*$ & 14.1 & 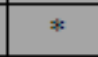 & 15.6 & 21.7 & 11.4 \\
\hline $\mathrm{D} 2$ & 7 & 16.7 & 24.1 & 18.0 & $*$ & 14.4 & $*$ & $*$ & 14.7 & * & 17.6 & 23.9 & 12.8 \\
\hline $\mathrm{T} 1$ & 19.2 & 13.8 & 20.6 & 13.5 & * & 14.2 & $*$ & * & 14.5 & * & 14.6 & 21.0 & 11.3 \\
\hline $\mathrm{T} 2$ & 18.2 & 14.3 & 21.4 & 15.4 & * & 13.6 & $*$ & $*$ & 14.1 & $*$ & 14.4 & 20.8 & 12.1 \\
\hline
\end{tabular}

HMA over Rubblized PCC Base

\begin{tabular}{|c|c|c|c|c|c|c|c|c|c|c|c|c|c|}
\hline \multirow[b]{2}{*}{ Axle } & \multirow{2}{*}{$\begin{array}{c}\text { Axle Weight, } \\
\text { kips }\end{array}$} & \multicolumn{12}{|c|}{ Strain, microstrain } \\
\hline & & RBO1 & RBO2 & RBO3 & RB04 & RB05 & RBO6 & RB07 & RBO8 & RBO9 & RB10 & RB11 & RB12 \\
\hline S & 12.9 & * & 10.9 & 7.6 & 2.7 & 5.0 & * & 2.9 & 4.1 & * & $* *$ & * & 6.3 \\
\hline D1 & 17.6 & * & 10.2 & 6.1 & 2.4 & 6.8 & * & 3.1 & 6.1 & * & $* *$ & * & 6.4 \\
\hline $\mathrm{D} 2$ & 17.7 & * & \begin{tabular}{|l|}
11.8 \\
\end{tabular} & 7.8 & 2.6 & 7.5 & * & 3.1 & 6.7 & * & $* *$ & * & 6.6 \\
\hline $\mathrm{T} 1$ & 19.2 & * & 10.3 & 6.4 & 2.2 & 6.6 & $*$ & 3.1 & 6.2 & * & $* *$ & $*$ & 6.4 \\
\hline $\mathrm{T} 2$ & 18.2 & * & \begin{tabular}{|l|}
11.7 \\
\end{tabular} & 8.6 & 2.7 & 6.0 & $*$ & 3.1 & 5.2 & * & $* *$ & * & 7.0 \\
\hline
\end{tabular}

Shading:

Longitudinal gages

Tranverse gages

- Unable to determine due to poor gage response

* Gage was not responding
Axles:

$\mathrm{S}=$ steering axle

D1 = first drive axle

D2 = second drive axle

$\mathrm{T} 1$ = first trailer axle

$\mathrm{T} 2$ = second trailer axle 
Date: 23-Jan-08 Strain Data File: 23 Jan011.xlsx $\quad$ WIM VEN: 555

HMA over Aggregate Base

\begin{tabular}{|c|c|c|c|c|c|c|c|c|c|c|c|c|c|}
\hline \multirow[b]{2}{*}{ Axle } & \multirow{2}{*}{$\begin{array}{c}\text { Axle Weight, } \\
\text { kips }\end{array}$} & \multicolumn{12}{|c|}{ Strain, microstrain } \\
\hline & & AB01 & $\mathrm{AB} 02$ & AB03 & AB04 & AB05 & AB06 & AB07 & AB08 & AB09 & AB10 & AB11 & AB12 \\
\hline$S$ & 11.4 & 11.9 & 16.6 & 23.0 & 4.8 & $*$ & $*$ & $*$ & 4.7 & $*$ & 12.1 & 18.3 & 18.3 \\
\hline D1 & 20.6 & 13.8 & 19.5 & 22.1 & 3.0 & $*$ & $*$ & $*$ & 9.4 & * & 13.9 & 20.5 & 17.8 \\
\hline D2 & 20.6 & 14.4 & 19.2 & 21.2 & 2.5 & $*$ & $*$ & $*$ & 8.5 & * & 14.5 & 20.0 & 16.8 \\
\hline $\mathrm{T} 1$ & 24.2 & 10.5 & 15.8 & 15.2 & 2.1 & $*$ & $*$ & $*$ & 9.2 & * & 10.9 & 16.2 & 12.4 \\
\hline $\mathrm{T} 2$ & 25.5 & 11.4 & 17.1 & 15.1 & 1.5 & * & * & * & 10.1 & & 11.7 & 16.9 & 11.9 \\
\hline
\end{tabular}

HMA over Rubblized PCC Base

\begin{tabular}{|c|c|c|c|c|c|c|c|c|c|c|c|c|c|}
\hline \multirow[b]{2}{*}{ Axle } & \multirow{2}{*}{$\begin{array}{c}\text { Axle Weight, } \\
\text { kips }\end{array}$} & \multicolumn{12}{|c|}{ Strain, microstrain } \\
\hline & & RBO1 & $\mathrm{RBO2}$ & RBO3 & RB04 & RB05 & RBO6 & RBO7 & RBO8 & RBO9 & RB10 & RB11 & RB12 \\
\hline $\mathrm{S}$ & 11.4 & * & 7.7 & 11.8 & 3.4 & * & * & 3.0 & * & $*$ & $* *$ & * & 11.7 \\
\hline D1 & 20.6 & $*$ & 8.9 & 9.9 & 3.3 & $*$ & $*$ & 3.0 & * & $*$ & $* *$ & $*$ & 9.9 \\
\hline D2 & 20.6 & * & 8.8 & 10.0 & 3.5 & * & $*$ & 2.9 & $*$ & * & ** & $*$ & 8.8 \\
\hline $\mathrm{T} 1$ & 24.2 & * & 7.7 & 7.2 & 2.6 & * & * & 2.4 & * & * & $* *$ & * & 7.0 \\
\hline $\mathrm{T} 2$ & 25.5 & * & 8.0 & 7.4 & 2.8 & * & * & 2.7 & * & * & $* *$ & * & 6.2 \\
\hline
\end{tabular}

Shading:

Longitudinal gages

Tranverse gages

- Unable to determine due to poor gage response

* Gage was not responding
Axles:

$S=$ steering axle

D1 = first drive axle

D2 = second drive axle

T1 = first trailer axle

$\mathrm{T} 2$ = second trailer axle 
Date: 23-Jan-08 Strain Data File: 23 23an013.xIsx $\quad$ WIM VEN: 564

HMA over Aggregate Base

\begin{tabular}{|c|c|c|c|c|c|c|c|c|c|c|c|c|c|}
\hline \multirow[b]{2}{*}{ Axle } & \multirow{2}{*}{$\begin{array}{c}\text { Axle Weight, } \\
\text { kips }\end{array}$} & \multicolumn{12}{|c|}{ Strain, microstrain } \\
\hline & & ABO & ABO2 & $\mathrm{ABO3}$ & ABO4 & AB05 & AB06 & AB07 & AB08 & ABO9 & AB10 & AB1: & AB12 \\
\hline S & 11.4 & 11.8 & 13.7 & 27.9 & 5.1 & * & 20.2 & 3.4 & $*$ & * & 12.8 & 15.3 & 24.4 \\
\hline D1 & 9.8 & 12.8 & 14.0 & 27.9 & 1.8 & $*$ & 9.5 & 0.5 & * & * & 9.0 & 10.6 & 12.6 \\
\hline $\mathrm{D} 2$ & 9.8 & 9.7 & 10.9 & 22.7 & 2.2 & * & 9.5 & 0.5 & $*$ & * & 9.6 & 11.2 & 13.2 \\
\hline T1 & 9.7 & 7.4 & 8.4 & 15.2 & 2.2 & $*$ & 10.4 & 0.8 & $*$ & * & 7.7 & 8.8 & 12.0 \\
\hline $\mathrm{T} 2$ & 9.7 & 8.0 & 9.2 & 17.0 & 1.4 & $*$ & 9.7 & 0.8 & $*$ & * & 7.6 & 8.9 & 12.3 \\
\hline
\end{tabular}

HMA over Rubblized PCC Base

\begin{tabular}{|c|c|c|c|c|c|c|c|c|c|c|c|c|c|}
\hline \multirow[b]{2}{*}{ Axle } & \multirow{2}{*}{\begin{tabular}{|c|}
$\begin{array}{c}\text { Axle Weight, } \\
\text { kips }\end{array}$ \\
\end{tabular}} & \multicolumn{12}{|c|}{ Strain, microstrain } \\
\hline & & RBO1 & $\mathrm{RBO} 2$ & RBO3 & RBO4 & RB05 & RB06 & RBO7 & RB08 & RBO9 & RB10 & RB11 & RB12 \\
\hline $\mathrm{S}$ & 11.4 & $*$ & 6.3 & 13.3 & 2.8 & $*$ & $*$ & 2.0 & $*$ & $*$ & $* *$ & $*$ & 13.4 \\
\hline D1 & 9.8 & $*$ & 5.0 & 6.3 & 1.2 & $*$ & $*$ & 0.9 & $*$ & $*$ & $* *$ & $*$ & 6.3 \\
\hline D2 & 9.8 & * & 4.6 & 6.8 & 1.6 & * & * & 0.9 & $*$ & $*$ & $* *$ & * & 6.6 \\
\hline $\mathrm{T} 1$ & 9.7 & $*$ & 3.8 & 6.0 & 1.2 & $*$ & $*$ & 1.0 & $*$ & $*$ & $* *$ & $*$ & 6.9 \\
\hline $\mathrm{T} 2$ & 9.7 & $*$ & 4.1 & 7.0 & 1.6 & $*$ & $*$ & 1.0 & $*$ & $*$ & $* *$ & $*$ & 6.8 \\
\hline
\end{tabular}

Shading:

Longitudinal gages

Tranverse gages

-Unable to determine due to poor gage response

* Gage was not responding
Axles:

$$
\begin{aligned}
& S=\text { steering axle } \\
& D 1=\text { first drive axle } \\
& D 2 \text { = second drive axle } \\
& T 1=\text { first trailer axle } \\
& T 2=\text { second trailer axle }
\end{aligned}
$$


Date: 23-Jan-08 Strain Data File: 23 23an015.xlsx $\quad$ WIM VEN: $\quad 572$

HMA over Aggregate Base

\begin{tabular}{|c|c|c|c|c|c|c|c|c|c|c|c|c|c|}
\hline \multirow[b]{2}{*}{ Axle } & \multirow{2}{*}{$\begin{array}{c}\text { Axle Weight, } \\
\text { kips }\end{array}$} & \multicolumn{12}{|c|}{ Strain, microstrain } \\
\hline & & AB01 & $\mathrm{ABO2}$ & $\mathrm{ABO3}$ & $\mathrm{ABO}$ & $\mathrm{ABO}$ & ABO6 & ABO7 & AB08 & ABO9 & AB 10 & AB11 & AB12 \\
\hline$S$ & 14.2 & 12.9 & 17.8 & 26.7 & * & * & 11.3 & 3.9 & * & 8.6 & 14.2 & 19.9 & 21.7 \\
\hline D1 & 11.1 & 8.9 & 11.0 & 14.5 & * & * & 7.8 & 0.5 & * & 5.2 & 9.5 & 12.4 & 11.3 \\
\hline $\mathrm{D} 2$ & 10.6 & 9.0 & 11.3 & 15.1 & * & * & 8.6 & 1.4 & * & 5.7 & 9.5 & 12.2 & 11.0 \\
\hline $\mathrm{T} 1$ & 9.7 & 6.2 & 8.4 & 13.5 & $*$ & $*$ & 7.4 & 1.3 & * & 5.3 & 6.8 & 9.7 & 10.6 \\
\hline $\mathrm{T} 2$ & 8.9 & 6.0 & 7.9 & 13.2 & * & $*$ & 7.8 & 1.3 & $*$ & 5.2 & 6.4 & 9.2 & 10.2 \\
\hline
\end{tabular}

HMA over Rubblized PCC Base

\begin{tabular}{|c|c|c|c|c|c|c|c|c|c|c|c|c|c|}
\hline \multirow[b]{2}{*}{ Axle } & \multirow{2}{*}{$\begin{array}{c}\text { Axle Weight, } \\
\text { kips }\end{array}$} & \multicolumn{12}{|c|}{ Strain, microstrain } \\
\hline & & RBO1 & RBO2 & RBO3 & RBO4 & RB05 & RB06 & RBO7 & RB08 & RBO9 & RB10 & RB11 & RB12 \\
\hline $\mathrm{s}$ & 14.2 & * & 8.4 & 12.0 & 3.6 & * & * & 3.0 & * & * & $* *$ & * & 12.4 \\
\hline D1 & 11.1 & * & 5.1 & 5.7 & 1.5 & * & * & 1.6 & * & * & $* *$ & * & 7.2 \\
\hline $\mathrm{D} 2$ & 10.6 & * & 5.3 & 6.0 & 1.9 & * & * & 1.6 & * & * & $* *$ & * & 5.0 \\
\hline T1 & 9.7 & * & 4.2 & 5.9 & 1.7 & * & $*$ & 1.4 & * & * & $* *$ & * & 5.8 \\
\hline $\mathrm{T} 2$ & 8.9 & * & 4.0 & 5.8 & 1.8 & * & * & 1.3 & * & * & $* *$ & * & 5.5 \\
\hline
\end{tabular}

Shading:

Longitudinal gages

Tranverse gages

-Unable to determine due to poor gage response

* Gage was not responding
Axles:

$$
\begin{aligned}
& \mathrm{S}=\text { steering axle } \\
& \mathrm{D} 1 \text { = first drive axle } \\
& \mathrm{D} 2 \text { = second drive axle } \\
& \mathrm{T} 1 \text { = first trailer axle } \\
& \mathrm{T} 2 \text { = second trailer axle }
\end{aligned}
$$


Date: 23-Jan-08 Strain Data File: 23 23an016.xlsx $\quad$ WIM VEN: 576

HMA over Aggregate Base

\begin{tabular}{|c|c|c|c|c|c|c|c|c|c|c|c|c|c|}
\hline \multirow[b]{2}{*}{ Axle } & \multirow{2}{*}{$\begin{array}{c}\text { Axle Weight, } \\
\text { kips }\end{array}$} & \multicolumn{12}{|c|}{ Strain, microstrain } \\
\hline & & $A B 01$ & AB02 & AB03 & AB04 & AB05 & AB06 & ABO7 & AB08 & ABO9 & AB10 & AB11 & AB12 \\
\hline 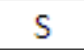 & 13.2 & 11.1 & 17.0 & 17.7 & * & * & * & * & 7.8 & 3.6 & 12.3 & 20.4 & 14.6 \\
\hline D1 & 15.3 & 10.4 & 15.1 & 14.5 & * & * & * & * & 8.7 & 3.2 & 10.9 & 16.1 & 10.8 \\
\hline $\mathrm{D} 2$ & 12.4 & 9.4 & 13.1 & 11.1 & * & * & * & * & 8.6 & 3.2 & 10.1 & 13.8 & 8.2 \\
\hline T1 & 8.4 & 6.5 & 9.5 & 9.3 & * & * & * & * & 5.9 & 2.9 & 6.8 & 9.4 & 6.9 \\
\hline $\mathrm{T} 2$ & 5.8 & 6.7 & 9.7 & 9.2 & * & * & * & * & 4.8 & 2.2 & 6.9 & 9.4 & 6.7 \\
\hline
\end{tabular}

HMA over Rubblized PCC Base

\begin{tabular}{|c|c|c|c|c|c|c|c|c|c|c|c|c|c|}
\hline \multirow[b]{2}{*}{ Axle } & \multirow{2}{*}{$\begin{array}{c}\text { Axle Weight, } \\
\text { kips }\end{array}$} & \multicolumn{12}{|c|}{ Strain, microstrain } \\
\hline & & RBO1 & RBO2 & RBO3 & RB04 & RB05 & RB06 & RB07 & RB08 & RBO9 & RB10 & RB11 & RB12 \\
\hline$S$ & 13.2 & * & 8.8 & 8.2 & 3.4 & 2.7 & $*$ & $*$ & $*$ & $*$ & ** & $*$ & 7.4 \\
\hline D1 & 15.3 & * & 6.8 & 5.3 & 2.2 & 3.9 & * & 2.4 & 3.1 & * & $* *$ & * & 5.5 \\
\hline $\mathrm{D} 2$ & 12.4 & * & 6.5 & 4.6 & 2.2 & 5.3 & $*$ & 2.0 & 4.4 & * & $* *$ & * & 3.2 \\
\hline T1 & 8.4 & * & 5.0 & 4.0 & 1.8 & 2.0 & * & 1.9 & 1.6 & * & $* *$ & * & 3.9 \\
\hline $\mathrm{T} 2$ & 5.8 & * & 4.4 & 4.2 & 2.0 & 2.5 & * & 1.8 & 2.1 & * & $* *$ & * & 3.5 \\
\hline
\end{tabular}

Shading:

Longitudinal gages

Tranverse gages

- Unable to determine due to poor gage response

*Gage was not responding
Axles:

$$
S=\text { steering axle }
$$

D1 = first drive axle

D2 = second drive axle

$\mathrm{T} 1$ = first trailer axle

T2 = second trailer axle 
Date: 23-Jan-08 Strain Data File: 23 23an024.xIsx $\quad$ WIM VEN: 610

HMA over Aggregate Base

\begin{tabular}{|c|c|c|c|c|c|c|c|c|c|c|c|c|c|}
\hline \multirow[b]{2}{*}{ Axle } & \multirow{2}{*}{$\begin{array}{c}\text { Axle Weight, } \\
\text { kips }\end{array}$} & \multicolumn{12}{|c|}{ Strain, microstrain } \\
\hline & & $A B 01$ & AB02 & AB03 & AB04 & AB05 & AB06 & $\mathrm{ABO7}$ & AB08 & ABOS & AB10 & AB11 & AB12 \\
\hline S & 12.3 & \begin{tabular}{|l|}
11.7 \\
\end{tabular} & 14.9 & 27.4 & 5.1 & * & 15.1 & 3.8 & 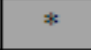 & 11.0 & 12.5 & 16.8 & 22.4 \\
\hline D1 & 16.3 & 13.9 & 17.7 & 25.9 & 3.6 & * & 14.8 & 2.0 & 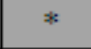 & 10.5 & 14.3 & 19.1 & 21.2 \\
\hline $\mathrm{D} 2$ & 16.0 & 14.9 & 18.4 & 26.1 & 2.3 & * & 15.0 & 1.6 & * & 11.1 & 15.3 & 19.1 & 21.1 \\
\hline $\mathrm{T} 1$ & 15.2 & 12.1 & 16.3 & 22.4 & 5.7 & * & 13.0 & 1.1 & * & 8.9 & 12.8 & 18.4 & 17.6 \\
\hline T2 & 15.6 & \begin{tabular}{|l|l}
13.1 \\
\end{tabular} & 16.0 & 23.4 & 1.7 & * & \begin{tabular}{|l|l}
13.6 \\
\end{tabular} & 1.5 & $*$ & 9.4 & 13.2 & 16.9 & 18.3 \\
\hline
\end{tabular}

HMA over Rubblized PCC Base

\begin{tabular}{|c|c|c|c|c|c|c|c|c|c|c|c|c|c|}
\hline \multirow[b]{2}{*}{ Axle } & \multirow{2}{*}{$\begin{array}{c}\text { Axle Weight, } \\
\text { kips }\end{array}$} & \multicolumn{12}{|c|}{ Strain, microstrain } \\
\hline & & RBO1 & RBO2 & RBO3 & RBO4 & RB05 & RB06 & RBO7 & RBO8 & RBOS & RB10 & RB11 & RB12 \\
\hline $\mathrm{S}$ & 12.3 & $*$ & 7.0 & 13.5 & 4.3 & * & * & 2.5 & * & * & $* *$ & * & 13.8 \\
\hline D1 & 16.3 & $*$ & 8.1 & 11.2 & 3.0 & * & * & 2.5 & * & * & $* *$ & * & 1.7 \\
\hline $\mathrm{D} 2$ & 16.0 & * & 8.1 & 11.9 & 3.4 & * & * & 2.3 & * & * & $* *$ & * & 10.5 \\
\hline T1 & 15.2 & * & 8.2 & 10.2 & 2.4 & * & * & 2.4 & $*$ & * & $* *$ & * & 14.0 \\
\hline $\mathrm{T} 2$ & 15.6 & * & 7.4 & 10.7 & 2.9 & * & * & 2.3 & $*$ & * & $* *$ & * & 14.0 \\
\hline
\end{tabular}

Shading:

Longitudinal gages

Tranverse gages

- Unable to determine due to poor gage response

*Gage was not responding
Axles:

$\mathrm{S}=$ steering axle

D1 = first drive axle

D2 = second drive axle

$T 1$ = first trailer axle

T2 = second trailer axle 
Date: 23-Jan-08 Strain Data File: $\quad$ 23Jan027.xIsx $\quad$ WIM VEN: $\quad 634$

HMA over Aggregate Base

\begin{tabular}{|c|c|c|c|c|c|c|c|c|c|c|c|c|c|}
\hline \multirow[b]{2}{*}{ Axle } & \multirow{2}{*}{$\begin{array}{c}\text { Axle Weight, } \\
\text { kips }\end{array}$} & \multicolumn{12}{|c|}{ Strain, microstrain } \\
\hline & & AB01 & AB02 & AB03 & AB04 & AB05 & AB06 & AB07 & AB08 & ABOS & AB10 & AB11 & $\mathrm{AB} 12$ \\
\hline S & 13.7 & 14.0 & 23.5 & 15.8 & 2.8 & 14.8 & 2.8 & 2.6 & 16.9 & 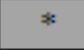 & 15.2 & 25.7 & 12.9 \\
\hline D1 & 21.1 & 20.4 & 30.0 & 19.4 & 2.1 & 20.4 & 3.3 & -0.4 & 20.3 & 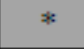 & 21.8 & 31.6 & 16.5 \\
\hline D2 & 22.7 & 23.3 & 33.5 & 22.1 & 0.2 & 20.4 & 5.3 & 0.0 & 20.2 & 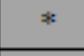 & 23.3 & 32.1 & 16.7 \\
\hline T1 & 24.0 & 18.0 & 26.9 & 17.3 & 4.1 & 21.5 & 4.9 & 2.9 & 21.0 & $*$ & 20.2 & 29.6 & 15.1 \\
\hline $\mathrm{T} 2$ & 27.9 & 24.3 & 35.1 & 22.7 & 1.2 & 22.2 & 3.3 & 1.3 & 22.8 & * & 25.4 & 36.0 & 18.1 \\
\hline
\end{tabular}

HMA over Rubblized PCC Base

\begin{tabular}{|c|c|c|c|c|c|c|c|c|c|c|c|c|c|}
\hline \multirow[b]{2}{*}{ Axle } & \multirow{2}{*}{$\begin{array}{c}\text { Axle Weight, } \\
\text { kips }\end{array}$} & \multicolumn{12}{|c|}{ Strain, microstrain } \\
\hline & & RB01 & RBO2 & RBO3 & RB04 & RB05 & RB06 & RB07 & RB08 & RBO9 & RB10 & RB11 & RB12 \\
\hline$S$ & 13.7 & $*$ & 11.2 & 6.1 & 2.5 & 9.7 & $*$ & 3.3 & 9.6 & * & $* *$ & * & 5.6 \\
\hline D1 & 21.1 & * & 13.3 & 6.8 & 1.8 & 9.3 & * & 3.8 & 8.4 & * & $* *$ & * & 7.1 \\
\hline $\mathrm{D} 2$ & 22.7 & * & 16.3 & 8.6 & 2.4 & 10.5 & * & 4.0 & 9.0 & * & $* *$ & * & 6.8 \\
\hline $\mathrm{T} 1$ & 24.0 & $*$ & 12.2 & 5.9 & 1.7 & 7.9 & * & 3.9 & 8.4 & * & $* *$ & * & 6.3 \\
\hline $\mathrm{T} 2$ & 27.9 & * & 17.0 & 9.0 & 2.7 & 11.1 & * & 4.5 & 9.9 & * & $* *$ & $*$ & 7.4 \\
\hline
\end{tabular}

Shading:

Longitudinal gages

Tranverse gages

- Unable to determine due to poor gage response

*Gage was not responding

$$
\begin{aligned}
& \text { Axles: } \\
& \begin{array}{l}
\text { S = steering axle } \\
D 1 \text { = first drive axle } \\
D 2 \text { = second drive axle } \\
T 1=\text { first trailer axle } \\
T 2=\text { second trailer axle }
\end{array}
\end{aligned}
$$


Date: 23-Jan-08 Strain Data File: 23 23an030.xlsx $\quad$ WIM VEN: $\underline{646}$

HMA over Aggregate Base

\begin{tabular}{|c|c|c|c|c|c|c|c|c|c|c|c|c|c|}
\hline \multirow[b]{2}{*}{ Axle } & \multirow{2}{*}{$\begin{array}{c}\text { Axle Weight, } \\
\text { kips }\end{array}$} & \multicolumn{12}{|c|}{ Strain, microstrain } \\
\hline & & AB01 & $\mathrm{ABO2}$ & AB03 & AB04 & AB05 & AB06 & AB07 & AB08 & AB09 & $\mathrm{AB} 10$ & AB11 & AB12 \\
\hline $\mathrm{s}$ & 13.5 & 13.3 & 22.5 & 16.4 & 3.1 & \begin{tabular}{|l|}
14.4 \\
\end{tabular} & * & 2.3 & 16.6 & 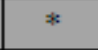 & 13.9 & 23.5 & 11.6 \\
\hline D1 & 25.6 & 19.1 & 29.4 & 19.5 & 1.4 & 20.1 & * & 0.6 & 20.0 & * & 9.8 & 8.6 & 7.2 \\
\hline $\mathrm{D} 2$ & 24.2 & 20.3 & 30.0 & 21.2 & 1.3 & 19.6 & * & 0.7 & 19.2 & * & 20.5 & 30.3 & 17.1 \\
\hline $\mathrm{T} 1$ & 25.1 & 19.0 & 30.9 & 24.5 & 3.5 & 19.4 & * & 1.9 & 19.6 & * & 19.3 & 32.0 & 19.8 \\
\hline $\mathrm{T} 2$ & 26.6 & 20.2 & 31.2 & 25.9 & 2.8 & \begin{tabular}{|l|}
19.7 \\
\end{tabular} & $*$ & 2.3 & 19.5 & * & 20.2 & 31.2 & 20.0 \\
\hline
\end{tabular}

HMA over Rubblized PCC Base

\begin{tabular}{|c|c|c|c|c|c|c|c|c|c|c|c|c|c|}
\hline \multirow[b]{2}{*}{ Axle } & \multirow{2}{*}{$\begin{array}{c}\text { Axle Weight, } \\
\text { kips }\end{array}$} & \multicolumn{12}{|c|}{ Strain, microstrain } \\
\hline & & RB01 & RB02 & RBO3 & RB04 & RB05 & RB06 & RB07 & RB08 & RBO9 & RB10 & RB11 & RB12 \\
\hline$S$ & 13.5 & * & 11.4 & 5.8 & 2.2 & 10.9 & * & 3.2 & 10.8 & $*$ & $* *$ & $*$ & 4.7 \\
\hline D1 & 25.6 & * & 14.1 & 7.2 & 2.4 & 10.3 & * & 4.2 & 8.9 & * & $* *$ & $*$ & 6.9 \\
\hline D2 & 24.2 & $*$ & 14.8 & 8.4 & 2.7 & 9.9 & $*$ & 3.9 & 8.6 & * & $* *$ & $*$ & 6.7 \\
\hline T1 & 25.1 & $*$ & 16.3 & 10.1 & 3.6 & 10.8 & $*$ & 4.5 & 8.9 & * & $* *$ & $*$ & 9.0 \\
\hline $\mathrm{T} 2$ & 26.6 & * & 17.7 & 11.7 & 4.3 & 10.9 & $*$ & 4.7 & 8.9 & * & $* *$ & * & 8.4 \\
\hline
\end{tabular}

Shading:

Longitudinal gages

Tranverse gages

*Unable to determine due to poor gage response

* Gage was not responding
Axles:

$$
\begin{aligned}
& S \text { = steering axle } \\
& D 1=\text { first drive axle } \\
& D 2 \text { = second drive axle } \\
& T 1=\text { first trailer axle } \\
& T 2=\text { second trailer axle }
\end{aligned}
$$


Date: 23-Jan-08 Strain Data File: 23 Jan041.xlsx $\quad$ WIM VEN:

HMA over Aggregate Base

\begin{tabular}{|c|c|c|c|c|c|c|c|c|c|c|c|c|c|}
\hline \multirow[b]{2}{*}{ Axle } & \multirow{2}{*}{$\begin{array}{c}\text { Axle Weight, } \\
\text { kips }\end{array}$} & \multicolumn{12}{|c|}{ Strain, microstrain } \\
\hline & & ABO1 & AB02 & AB03 & AB04 & AB05 & AB06 & AB07 & ABO 8 & ABO9 & $A B 10$ & AB11 & $A B 12$ \\
\hline$S$ & 12.3 & 11.8 & 17.6 & 20.3 & 4.4 & 5.5 & . & * & 6.7 & 4.7 & 12.3 & 19.9 & 16.1 \\
\hline D1 & 12.4 & 10.2 & 13.1 & 12.7 & 1.9 & 6.6 & 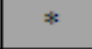 & ? & 7.1 & 3.6 & 14.4 & 17.4 & 13.8 \\
\hline $\mathrm{D} 2$ & 12.6 & 10.0 & 13.2 & 12.7 & 1.7 & 6.6 & - & $*$ & 7.0 & 3.4 & 12.3 & 14.7 & 10.4 \\
\hline $\mathrm{T} 1$ & 8.2 & 7.5 & 12.1 & 9.2 & 2.1 & 8.4 & $*$ & $*$ & 8.5 & 2.5 & 7.8 & \begin{tabular}{|l|l}
11.7 \\
\end{tabular} & 7.5 \\
\hline $\mathrm{T} 2$ & 7.4 & 7.2 & 10.9 & 8.9 & 0.2 & 8.0 & $*$ & * & 8.1 & 2.5 & 7.4 & 11.1 & 6.8 \\
\hline
\end{tabular}

HMA over Rubblized PCC Base

\begin{tabular}{|c|c|c|c|c|c|c|c|c|c|c|c|c|c|}
\hline \multirow[b]{2}{*}{ Axle } & \multirow{2}{*}{$\begin{array}{c}\text { Axle Weight, } \\
\text { kips }\end{array}$} & \multicolumn{12}{|c|}{ Strain, microstrain } \\
\hline & & RB01 & RBO2 & RBO3 & RB04 & RB05 & RB06 & RBO7 & RB08 & RBO9 & RB10 & RB11 & RB12 \\
\hline$S$ & 12.3 & * & 10.6 & 8.0 & 2.9 & 5.2 & * & 3.2 & 4.5 & * & $* *$ & * & 6.9 \\
\hline D1 & 12.4 & * & 9.2 & 7.1 & 1.2 & 2.7 & * & 1.8 & 3.3 & * & $* *$ & * & 3.8 \\
\hline $\mathrm{D} 2$ & 12.6 & * & 7.8 & 4.7 & 1.8 & 4.7 & * & 2.0 & 3.8 & $*$ & $* *$ & $*$ & 3.1 \\
\hline $\mathrm{T} 1$ & 8.2 & * & 5.5 & 3.0 & 0.7 & 3.6 & * & 1.6 & 3.5 & $*$ & $* *$ & $*$ & 3.0 \\
\hline $\mathrm{T} 2$ & 7.4 & $*$ & 5.4 & 3.3 & 0.7 & 4.3 & * & 1.7 & 4.2 & $*$ & $* *$ & * & 2.6 \\
\hline
\end{tabular}

Shading:

Longitudinal gages

Tranverse gages

- Unable to determine due to poor gage response

* Gage was not responding
Axles:

$S=$ steering axle

D1 = first drive axle

$\mathrm{D} 2$ = second drive axle

T1 = first trailer axle

$T 2$ = second trailer axle 
Date: $\quad$ 23-Jan-08 Strain Data File: $\quad$ 23Jan045.xlsx $\quad$ WIM VEN: $\underline{724}$

HMA over Aggregate Base

\begin{tabular}{|c|c|c|c|c|c|c|c|c|c|c|c|c|c|}
\hline \multirow[b]{2}{*}{ Axle } & \multirow{2}{*}{$\begin{array}{c}\text { Axle Weight, } \\
\text { kips }\end{array}$} & \multicolumn{12}{|c|}{ Strain, microstrain } \\
\hline & & AB01 & AB02 & AB03 & AB04 & AB05 & AB06 & AB07 & AB08 & AB09 & AB10 & AB11 & AB12 \\
\hline$S$ & 10.3 & 15.1 & 12.6 & 25.2 & $*$ & $*$ & 7.2 & $*$ & $*$ & 4.3 & 14.8 & 12.9 & 18.4 \\
\hline D1 & 11.8 & 18.4 & 16.8 & 31.0 & $*$ & $*$ & 16.5 & $*$ & $*$ & 11.7 & 19.1 & 17.7 & 26.4 \\
\hline $\mathrm{D} 2$ & 11.8 & 21.0 & 17.4 & 27.8 & * & * & 15.7 & $*$ & * & 10.8 & 21.4 & 17.6 & 24.1 \\
\hline $\mathrm{T} 1$ & 13.1 & 17.7 & 16.1 & 29.1 & $*$ & $*$ & 16.1 & * & $*$ & 10.6 & 17.9 & 16.4 & 23.0 \\
\hline $\mathrm{T} 2$ & 15.3 & 21.6 & 18.9 & 33.9 & * & * & 17.1 & * & * & 11.6 & 20.8 & 18.9 & 28.6 \\
\hline
\end{tabular}

HMA over Rubblized PCC Base

\begin{tabular}{|c|c|c|c|c|c|c|c|c|c|c|c|c|c|}
\hline \multirow[b]{2}{*}{ Axle } & \multirow{2}{*}{$\begin{array}{c}\text { Axle Weight, } \\
\text { kips }\end{array}$} & \multicolumn{12}{|c|}{ Strain, microstrain } \\
\hline & & RB01 & RBO2 & RB03 & RB04 & RB05 & RB06 & RB07 & RB08 & RBO9 & RB10 & RB11 & RB12 \\
\hline S & 10.3 & * & 4.9 & 6.8 & * & * & * & * & $*$ & * & $* *$ & * & 5.6 \\
\hline D1 & 11.8 & $*$ & 6.8 & 10.0 & $*$ & $*$ & $*$ & $*$ & $*$ & $*$ & $* *$ & $*$ & 9.7 \\
\hline D2 & 11.8 & * & 6.5 & 9.4 & * & * & * & * & * & * & $* *$ & $*$ & 7.9 \\
\hline $\mathrm{T} 1$ & 13.1 & $*$ & 6.2 & 8.5 & * & * & $*$ & $*$ & * & $*$ & $* *$ & $*$ & 8.0 \\
\hline $\mathrm{T} 2$ & 15.3 & $*$ & 7.2 & 11.2 & $*$ & $*$ & $*$ & $*$ & $*$ & $*$ & $* *$ & $*$ & 10.1 \\
\hline
\end{tabular}

Shading:

Longitudinal gages

Tranverse gages

- Unable to determine due to poor gage response

* Gage was not responding
Axles:

$$
\begin{aligned}
& S=\text { steering axle } \\
& D 1=\text { first drive axle } \\
& D 2=\text { second drive axle } \\
& T 1=\text { first trailer axle } \\
& T 2=\text { second trailer axle }
\end{aligned}
$$


Strain Data File: $\quad$ 23Jan049.xlsx

WIM VEN: 742

HMA over Aggregate Base

\begin{tabular}{|c|c|c|c|c|c|c|c|c|c|c|c|c|c|}
\hline \multirow[b]{2}{*}{ Axle } & \multirow{2}{*}{$\begin{array}{c}\text { Axle Weight, } \\
\text { kips }\end{array}$} & \multicolumn{12}{|c|}{ Strain, microstrain } \\
\hline & & AB01 & AB02 & ABO3 & AB04 & AB05 & AB06 & AB07 & AB08 & ABO9 & AB10 & AB11 & AB12 \\
\hline $\mathrm{s}$ & 14.4 & 11.8 & 17.8 & 20.5 & * & * & $*$ & 3.8 & 6.6 & 4.5 & 12.3 & 19.7 & 15.9 \\
\hline D1 & 16.4 & 12.4 & 15.0 & 15.9 & $*$ & * & 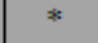 & 2.9 & 8.8 & 6.4 & 13.1 & 17.9 & 14.3 \\
\hline $\mathrm{D} 2$ & 15.8 & 11.5 & 16.4 & 18.1 & * & * & * & 2.4 & 8.4 & 5.5 & 12.1 & 17.9 & 14.5 \\
\hline $\mathrm{T} 1$ & 10.0 & 5.0 & 6.2 & 9.7 & $*$ & * & * & 2.5 & 2.7 & 4.6 & 6.1 & 8.3 & 9.1 \\
\hline $\mathrm{T} 2$ & 10.3 & 5.7 & 8.1 & 12.2 & * & * & * & 2.4 & 2.9 & 5.4 & 6.5 & 8.4 & 9.4 \\
\hline
\end{tabular}

HMA over Rubblized PCC Base

\begin{tabular}{|c|c|c|c|c|c|c|c|c|c|c|c|c|c|}
\hline \multirow[b]{2}{*}{ Axle } & \multirow{2}{*}{$\begin{array}{c}\text { Axle Weight, } \\
\text { kips }\end{array}$} & \multicolumn{12}{|c|}{ Strain, microstrain } \\
\hline & & RB01 & RB02 & RB03 & RB04 & RB05 & RB06 & RB07 & RB08 & RB09 & RB10 & RB11 & RB12 \\
\hline $\mathrm{s}$ & 14.4 & * & 10.2 & 8.7 & 2.9 & 3.5 & * & 3.2 & 2.9 & * & $* *$ & * & 7.6 \\
\hline D1 & 16.4 & * & 8.2 & 6.5 & 2.8 & 4.4 & * & 2.9 & 4.0 & * & $* *$ & * & 5.7 \\
\hline D2 & 15.8 & * & 8.9 & 7.4 & 3.1 & 4.4 & * & 3.0 & 3.7 & * & $* *$ & * & 6.3 \\
\hline $\mathrm{T} 1$ & 10.0 & * & 3.7 & 4.1 & 1.8 & 1.1 & $*$ & 1.6 & 0.6 & * & *** & * & 4.1 \\
\hline $\mathrm{T} 2$ & 10.3 & * & 4.3 & 5.4 & 1.9 & 1.2 & * & 1.7 & 1.1 & * & $* *$ & * & 4.3 \\
\hline
\end{tabular}

Shading:

Longitudinal gages

Tranverse gages

- Unable to determine due to poor gage response

* Gage was not responding
Axles:

$\mathrm{S}=$ steering axle

D1 = first drive axle

D2 = second drive axle

T1 = first trailer axle

$T 2$ = second trailer axle 
Date: 23-Jan-08 Strain Data File: $\quad$ 23Jan052.xIsx WIM VEN: 759

HMA over Aggregate Base

\begin{tabular}{|c|c|c|c|c|c|c|c|c|c|c|c|c|c|}
\hline \multirow[b]{2}{*}{ Axle } & \multirow{2}{*}{$\begin{array}{c}\text { Axle } \\
\text { Weight, }\end{array}$} & \multicolumn{12}{|c|}{ Strain, microstrain } \\
\hline & & ABO1 & ABO2 & ABO3 & ABO4 & ABO5 & AB06 & ABO7 & ABO8 & ABO9 & $A B 10$ & AB11 & AB12 \\
\hline S & 11.4 & 13.9 & 22.5 & 14.2 & * & 14.1 & 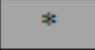 & $*$ & 14.4 & $*$ & 15.1 & 22.4 & 9.8 \\
\hline D1 & 16.0 & 16.5 & 20.9 & 12.5 & * & 13.6 & 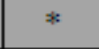 & 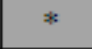 & 13.4 & . & 17.7 & 20.3 & 9.6 \\
\hline D2 & 16.1 & 17.5 & 21.6 & 13.4 & $*$ & 13.7 & * & - & 13.8 & * & 19.1 & 22.3 & 10.4 \\
\hline $\mathrm{T} 1$ & 14.8 & 15.1 & 21.9 & 14.0 & * & 15.0 & * & * & 14.9 & * & 15.8 & 21.0 & 10.6 \\
\hline $\mathrm{T} 2$ & 14.0 & 16.0 & 22.2 & 15.2 & * & 15.0 & * & * & 13.9 & * & 16.8 & 21.9 & 11.3 \\
\hline
\end{tabular}

HMA over Rubblized PCC Base

\begin{tabular}{|c|c|c|c|c|c|c|c|c|c|c|c|c|c|}
\hline \multirow[b]{2}{*}{ Axle } & \multirow{2}{*}{$\begin{array}{c}\text { Axle } \\
\text { Weight, }\end{array}$} & \multicolumn{12}{|c|}{ Strain, microstrain } \\
\hline & & RB01 & RBO2 & RB03 & RB04 & RB05 & RB06 & RB07 & RB08 & RB09 & RB10 & RB11 & RB12 \\
\hline $\mathrm{S}$ & 11.4 & $*$ & 9.7 & 4.2 & * & 7.1 & 1.4 & 2.6 & 6.8 & 1.5 & $* *$ & * & 3.4 \\
\hline D1 & 16.0 & * & 8.5 & 3.7 & * & 6.0 & 1.5 & 0.2 & 4.9 & 1.6 & $* *$ & * & 3.4 \\
\hline $\mathrm{D} 2$ & 16.1 & * & 9.3 & 4.5 & * & * & * & 0.2 & 5.4 & 2.0 & $* *$ & * & 3.1 \\
\hline T1 & 14.8 & $*$ & 9.6 & 4.2 & $*$ & 7.3 & 1.8 & 1.9 & 6.6 & 1.4 & $* *$ & * & 4.0 \\
\hline $\mathrm{T} 2$ & 14.0 & * & 10.8 & 5.3 & * & 7.9 & 1.3 & 1.8 & 6.7 & 1.7 & $* *$ & * & 3.6 \\
\hline
\end{tabular}

\section{Shading:}

Longitudinal gages

Tranverse gages

- Unable to determine due to poor gage response

* Gage was not responding
Axles:

$\mathrm{S}=$ steering axle

D1 = first drive axle

D2 = second drive axle

T1 = first trailer axle

$\mathrm{T} 2$ = second trailer axle 
Date: 23-Jan-08 Strain Data File: 23 23an067.xlsx $\quad$ WIM VEN: $\underline{835}$

HMA over Aggregate Base

\begin{tabular}{|c|c|c|c|c|c|c|c|c|c|c|c|c|c|}
\hline \multirow[b]{2}{*}{ Axle } & \multirow{2}{*}{$\begin{array}{c}\text { Axle Weight, } \\
\text { kips }\end{array}$} & \multicolumn{12}{|c|}{ Strain, microstrain } \\
\hline & & ABO1 & $\mathrm{ABO2}$ & ABO3 & ABO4 & AB05 & AB06 & ABO7 & AB08 & ABOS & $A B 10$ & $A B 11$ & $A B 12$ \\
\hline$S$ & 14.4 & 12.6 & 20.8 & 16.7 & 3.4 & * & * & 2.7 & * & * & 12.9 & 22.6 & 13.4 \\
\hline D1 & 12.3 & 8.9 & 13.3 & 10.0 & 0.9 & * & * & 0.4 & * & * & 13.3 & 20.9 & 13.0 \\
\hline D2 & 11.6 & 9.6 & 13.7 & 10.6 & 1.1 & * & * & 0.6 & * & * & 9.7 & 13.9 & 8.6 \\
\hline T1 & 11.5 & 6.7 & 9.6 & 8.7 & 3.7 & * & * & 2.0 & $*$ & * & 7.7 & 9.5 & 6.8 \\
\hline $\mathrm{T} 2$ & 11.1 & 7.4 & 10.3 & 9.5 & 1.7 & * & * & 1.5 & * & * & 8.1 & 10.7 & 7.8 \\
\hline
\end{tabular}

HMA over Rubblized PCC Base

\begin{tabular}{|c|c|c|c|c|c|c|c|c|c|c|c|c|c|}
\hline \multirow[b]{2}{*}{ Axle } & \multirow{2}{*}{$\begin{array}{c}\text { Axle Weight, } \\
\text { kips }\end{array}$} & \multicolumn{12}{|c|}{ Strain, microstrain } \\
\hline & & RB01 & RB02 & RBO3 & RB04 & RB05 & RB06 & RB07 & RB08 & RBO9 & RB10 & RB11 & RB12 \\
\hline$S$ & 14.4 & * & 10.2 & 7.9 & 3.0 & 4.6 & * & 3.3 & 4.0 & * & $* *$ & * & 6.8 \\
\hline D1 & 12.3 & * & 6.6 & 6.4 & 1.6 & 4.4 & * & 2.1 & 4.1 & * & $* *$ & * & 3.8 \\
\hline $\mathrm{D} 2$ & 11.6 & * & 6.3 & 4.8 & 1.9 & 4.6 & * & 2.1 & 4.1 & * & $* *$ & * & 3.9 \\
\hline $\mathrm{T} 1$ & 11.5 & * & 4.4 & 4.0 & 1.9 & 2.5 & * & 1.8 & 2.0 & * & $* *$ & * & 4.3 \\
\hline $\mathrm{T} 2$ & 11.1 & * & 4.7 & 4.8 & 2.1 & 2.6 & * & 1.9 & 2.1 & * & $* *$ & * & 4.1 \\
\hline
\end{tabular}

Shading:

Longitudinal gages

Tranverse gages

*Unable to determine due to poor gage response

* Gage was not responding

$$
\begin{aligned}
& \text { Axles: } \\
& \begin{array}{l}
\text { S }=\text { steering axle } \\
D 1=\text { first drive axle } \\
D 2=\text { second drive axle } \\
T 1=\text { first trailer axle } \\
T 2=\text { second trailer axle }
\end{array}
\end{aligned}
$$


Date: 23-Jan-08 Strain Data File: 23 23an071.xIsx $\quad$ WIM VEN: 860

HMA over Aggregate Base

\begin{tabular}{|c|c|c|c|c|c|c|c|c|c|c|c|c|c|}
\hline \multirow[b]{2}{*}{ Axle } & \multirow{2}{*}{$\begin{array}{c}\text { Axle Weight, } \\
\text { kips }\end{array}$} & \multicolumn{12}{|c|}{ Strain, microstrain } \\
\hline & & AB01 & AB02 & AB03 & AB04 & AB05 & AB06 & AB07 & AB08 & ABO9 & AB10 & AB11 & $\mathrm{AB} 12$ \\
\hline$S$ & 14.4 & 14.1 & 23.5 & 15.3 & 5.1 & 14.5 & * & 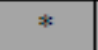 & 16.5 & 1.4 & 14.5 & 23.3 & 11.4 \\
\hline $\mathrm{D} 1$ & 26.3 & 19.0 & 27.0 & 21.7 & -0.9 & 7.8 & $*$ & $*$ & 17.8 & 2.2 & 20.2 & 28.5 & 14.5 \\
\hline $\mathrm{D} 2$ & 27.1 & 20.5 & 30.4 & 25.2 & 0.4 & 19.7 & * & * & 19.0 & 3.3 & 21.8 & 31.8 & 16.3 \\
\hline $\mathrm{T} 1$ & 25.8 & 20.6 & 29.0 & 17.1 & -0.3 & 19.7 & $*$ & ${ }^{*}$ & 18.3 & 1.9 & 21.7 & 29.0 & 13.7 \\
\hline $\mathrm{T} 2$ & 26.3 & 22.0 & 31.5 & 19.4 & -0.3 & 19.8 & * & $*$ & 19.2 & 2.5 & 22.2 & 30.2 & 14.8 \\
\hline
\end{tabular}

HMA over Rubblized PCC Base

\begin{tabular}{|c|c|c|c|c|c|c|c|c|c|c|c|c|c|}
\hline \multirow[b]{2}{*}{ Axle } & \multirow{2}{*}{$\begin{array}{c}\text { Axle Weight, } \\
\text { kips }\end{array}$} & \multicolumn{12}{|c|}{ Strain, microstrain } \\
\hline & & RB01 & RB02 & RBO3 & RB04 & RB05 & RB06 & RB07 & RB08 & RBO9 & RB10 & RB11 & RB12 \\
\hline$S$ & 14.4 & * & 11.6 & 5.8 & 1.9 & 10.3 & * & 3.3 & 10.6 & 1.0 & $* *$ & * & 4.6 \\
\hline D1 & 26.3 & * & 12.8 & 6.4 & 1.6 & 10.5 & * & 3.6 & 8.3 & 0.9 & $* *$ & * & 5.9 \\
\hline $\mathrm{D} 2$ & 27.1 & * & 15.1 & 8.1 & 1.9 & 11.0 & * & $*$ & $*$ & * & $* *$ & * & 6.0 \\
\hline $\mathrm{T} 1$ & 25.8 & * & 13.4 & 6.0 & 1.3 & 9.1 & * & 3.8 & 10.6 & 1.2 & $* *$ & * & 5.2 \\
\hline $\mathrm{T} 2$ & 26.3 & * & 14.6 & 7.5 & 1.4 & 10.1 & * & 3.5 & 8.5 & 1.5 & $* *$ & * & 5.2 \\
\hline
\end{tabular}

Shading:

Longitudinal gages

Tranverse gages

- Unable to determine due to poor gage response

* Gage was not responding

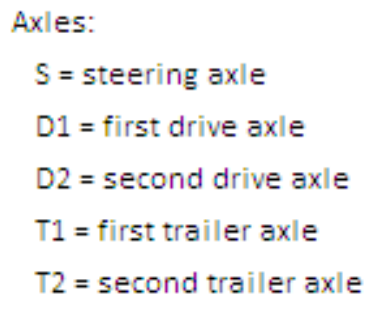


Date: 23-Jan-08 Strain Data File: 23 23an076.xlsx $\quad$ WIM VEN: $\underline{887}$

HMA over Aggregate Base

\begin{tabular}{|c|c|c|c|c|c|c|c|c|c|c|c|c|c|}
\hline \multirow[b]{2}{*}{ Axle } & \multirow{2}{*}{$\begin{array}{c}\text { Axle Weight, } \\
\text { kips }\end{array}$} & \multicolumn{12}{|c|}{ Strain, microstrain } \\
\hline & & ABO & $\mathrm{ABO2}$ & ABO3 & ABO4 & AB05 & AB06 & AB07 & AB08 & $A B 09$ & $A B 10$ & AB 11 & $\mathrm{AB} 12$ \\
\hline$S$ & 11.6 & 11.8 & 13.2 & 27.8 & 4.7 & $*$ & 20.9 & 3.7 & * & \begin{tabular}{|l}
15.2 \\
\end{tabular} & \begin{tabular}{|l|l}
10.4 \\
\end{tabular} & \begin{tabular}{|l}
11.8 \\
\end{tabular} & 12.6 \\
\hline D1 & 14.7 & 12.0 & 13.6 & 21.9 & 2.8 & $*$ & 12.9 & 0.5 & * & 8.7 & 13.7 & 15.8 & 24.4 \\
\hline $\mathrm{D} 2$ & 14.4 & \begin{tabular}{|l|l}
13.1 \\
\end{tabular} & 13.9 & 22.0 & 2.0 & * & 12.7 & 1.0 & * & 9.5 & 13.6 & \begin{tabular}{|l|}
14.7 \\
\end{tabular} & \begin{tabular}{|l|}
17.7 \\
\end{tabular} \\
\hline T1 & 10.8 & 9.1 & 11.1 & 18.4 & 2.3 & $*$ & 14.7 & 1.8 & * & 11.2 & 10.8 & 13.7 & 18.1 \\
\hline $\mathrm{T} 2$ & 10.5 & 10.2 & 13.1 & 25.3 & 2.5 & $*$ & 15.9 & 1.5 & * & 11.5 & 10.2 & 13.5 & 20.8 \\
\hline
\end{tabular}

HMA over Rubblized PCC Base

\begin{tabular}{|c|c|c|c|c|c|c|c|c|c|c|c|c|c|}
\hline \multirow[b]{2}{*}{ Axle } & \multirow{2}{*}{$\begin{array}{c}\text { Axle Weight, } \\
\text { kips } \\
\end{array}$} & \multicolumn{12}{|c|}{ Strain, microstrain } \\
\hline & & RBO1 & RBO2 & RBO3 & RB04 & RB05 & RB06 & RB07 & RB08 & RBO9 & RB10 & RB11 & RB12 \\
\hline $\mathrm{S}$ & 11.6 & $*$ & 6.8 & 12.7 & 3.3 & 0.4 & $*$ & 2.6 & $*$ & $*$ & $* *$ & $*$ & 12.3 \\
\hline D1 & 14.7 & $*$ & 7.6 & 11.3 & 2.9 & 1.2 & $*$ & 2.3 & $*$ & $*$ & $* *$ & $*$ & 10.1 \\
\hline D2 & 14.4 & * & 7.5 & 8.9 & 3.3 & 1.4 & $*$ & 2.2 & $*$ & $*$ & $* *$ & $*$ & 7.9 \\
\hline $\mathrm{T} 1$ & 10.8 & $*$ & 6.0 & 7.5 & 2.8 & 1.1 & $*$ & 2.6 & $*$ & $*$ & $* *$ & $*$ & 8.2 \\
\hline $\mathrm{T} 2$ & 10.5 & $*$ & 6.9 & 11.1 & 3.1 & 1.3 & $*$ & 2.6 & $*$ & $*$ & $* *$ & $*$ & 8.9 \\
\hline
\end{tabular}

Shading:

Longitudinal gages

Tranverse gages

-Unable to determine due to poor gage response

* Gage was not responding
Axles:

$$
\begin{aligned}
& \mathrm{S}=\text { steering axle } \\
& \mathrm{D} 1 \text { = first drive axle } \\
& \mathrm{D} 2 \text { = second drive axle } \\
& \mathrm{T} 1 \text { = first trailer axle } \\
& \mathrm{T} 2 \text { = second trailer axle }
\end{aligned}
$$


Date: 23-Jan-08 Strain Data File: 23 23an078.xlsx $\quad$ WIM VEN: $\underline{903}$

HMA over Aggregate Base

\begin{tabular}{|c|c|c|c|c|c|c|c|c|c|c|c|c|c|}
\hline \multirow[b]{2}{*}{ Axle } & \multirow{2}{*}{$\begin{array}{c}\text { Axle Weight, } \\
\text { kips }\end{array}$} & \multicolumn{12}{|c|}{ Strain, microstrain } \\
\hline & & AB01 & $A B 02$ & $\mathrm{ABO3}$ & ABO4 & AB05 & AB06 & AB07 & AB08 & ABO9 & AB10 & AB 11 & AB12 \\
\hline S & 13.7 & 10.8 & 17.0 & 18.0 & 3.9 & 6.5 & 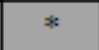 & 3.3 & 7.7 & . & 11.3 & 18.9 & 13.6 \\
\hline D1 & 26.5 & 19.3 & 30.3 & 25.5 & 3.9 & 19.3 & * & 3.0 & 20.1 & * & 20.8 & 33.4 & 21.7 \\
\hline $\mathrm{D} 2$ & 23.7 & 19.6 & 29.0 & 25.5 & 3.4 & 18.1 & * & 2.8 & 18.2 & * & 20.7 & 31.2 & 21.1 \\
\hline T1 & 24.7 & 18.1 & 27.1 & 22.6 & 4.0 & 18.9 & $*$ & 2.5 & 19.6 & * & 20.6 & 32.3 & 20.9 \\
\hline $\mathrm{T} 2$ & 23.4 & 20.4 & 31.5 & 27.0 & 3.3 & 19.8 & * & 2.9 & 20.5 & * & 21.2 & 33.2 & 22.5 \\
\hline
\end{tabular}

HMA over Rubblized PCC Base

\begin{tabular}{|c|c|c|c|c|c|c|c|c|c|c|c|c|c|}
\hline \multirow[b]{2}{*}{ Axle } & \multirow{2}{*}{$\begin{array}{c}\text { Axle Weight, } \\
\text { kips }\end{array}$} & \multicolumn{12}{|c|}{ Strain, microstrain } \\
\hline & & RBO1 & RBO2 & RBO3 & RBO4 & RB05 & RB06 & RBO7 & RBO8 & RBO9 & RB10 & RB11 & RB12 \\
\hline $\mathrm{S}$ & 13.7 & * & 8.9 & 8.4 & 2.6 & 2.7 & $*$ & 2.8 & 2.1 & $*$ & $* *$ & $*$ & 7.4 \\
\hline D1 & 26.5 & $*$ & 14.8 & 10.7 & 3.8 & 9.3 & $*$ & 4.5 & 8.2 & $*$ & $* *$ & $*$ & 10.8 \\
\hline D2 & 23.7 & $*$ & 14.6 & 11.6 & 4.4 & 8.6 & $*$ & 4.5 & 7.2 & $*$ & $* *$ & * & 10.5 \\
\hline $\mathrm{T} 1$ & 24.7 & $*$ & 13.6 & 9.8 & 3.9 & 7.8 & $*$ & 4.3 & 7.3 & $*$ & $* *$ & $*$ & 10.2 \\
\hline $\mathrm{T} 2$ & 23.4 & $*$ & 15.3 & 11.9 & 4.4 & 9.6 & * & 4.7 & 8.4 & $*$ & $* *$ & * & 11.4 \\
\hline
\end{tabular}

Shading:

Longitudinal gages

Tranverse gages

-Unable to determine due to poor gage response

* Gage was not responding
Axles:

$$
\begin{aligned}
& S=\text { steering axle } \\
& D 1=\text { first drive axle } \\
& D 2 \text { = second drive axle } \\
& T 1=\text { first trailer axle } \\
& T 2=\text { second trailer axle }
\end{aligned}
$$




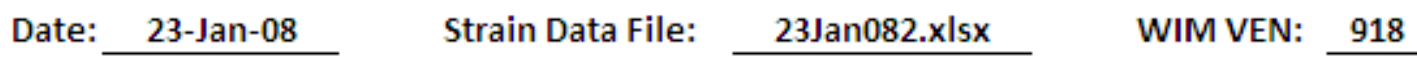

HMA over Aggregate Base

\begin{tabular}{|c|c|c|c|c|c|c|c|c|c|c|c|c|c|}
\hline \multirow[b]{2}{*}{ Axle } & \multirow{2}{*}{$\begin{array}{c}\text { Axle Weight, } \\
\text { kips }\end{array}$} & \multicolumn{12}{|c|}{ Strain, microstrain } \\
\hline & & AB01 & $\mathrm{AB02}$ & $\mathrm{ABO3}$ & $\mathrm{ABO4}$ & AB05 & AB06 & AB07 & AB08 & AB09 & AB10 & AB11 & $\mathrm{AB} 12$ \\
\hline$S$ & 14.4 & 10.7 & 19.1 & 13.2 & $*$ & 12.5 & $*$ & $*$ & 14.1 & $*$ & 11.5 & 19.4 & 9.3 \\
\hline D1 & 16.0 & 12.9 & 20.1 & 14.7 & * & 12.6 & $*$ & $*$ & 12.6 & $*$ & 12.2 & 16.7 & 9.0 \\
\hline D2 & 15.2 & 11.6 & 17.7 & 12.4 & * & 12.2 & * & * & 12.4 & * & 12.0 & 17.4 & 8.7 \\
\hline T1 & 13.6 & 9.0 & 14.4 & 10.4 & $*$ & 10.3 & $*$ & $*$ & 10.8 & $*$ & 9.8 & 14.4 & 7.9 \\
\hline $\mathrm{T} 2$ & 11.5 & 9.5 & 14.7 & 12.1 & $*$ & 10.1 & $*$ & $*$ & 10.1 & $*$ & 7.9 & 11.5 & 7.3 \\
\hline
\end{tabular}

HMA over Rubblized PCC Base

\begin{tabular}{|c|c|c|c|c|c|c|c|c|c|c|c|c|c|}
\hline \multirow[b]{2}{*}{ Axle } & \multirow{2}{*}{$\begin{array}{c}\text { Axle Weight, } \\
\text { kips }\end{array}$} & \multicolumn{12}{|c|}{ Strain, microstrain } \\
\hline & & RB01 & RB02 & RBO3 & RB04 & RB05 & RB06 & RB07 & RB08 & RBO9 & RB10 & RB11 & RB12 \\
\hline $\mathrm{S}$ & 14.4 & * & 7.3 & 3.2 & $*$ & 3.2 & 1.6 & 1.2 & 2.7 & * & $* *$ & * & 2.4 \\
\hline D1 & 16.0 & * & 5.5 & 3.3 & * & 3.1 & 1.4 & 0.3 & 2.4 & * & $* *$ & * & 2.4 \\
\hline $\mathrm{D} 2$ & 15.2 & * & 5.9 & 3.1 & * & 3.1 & 1.6 & 0.4 & 2.4 & * & $* *$ & * & 2.1 \\
\hline $\mathrm{T} 1$ & 13.6 & * & 5.3 & 2.3 & $*$ & 3.3 & 1.1 & 0.2 & 2.6 & * & $* *$ & * & 1.9 \\
\hline $\mathrm{T} 2$ & 11.5 & * & 5.9 & 3.0 & * & 4.3 & 1.3 & * & $*$ & * & $* *$ & * & 2.1 \\
\hline
\end{tabular}

Shading:

Longitudinal gages

Tranverse gages

*Unable to determine due to poor gage response

* Gage was not responding
Axles:

$\mathrm{S}=$ steering axle

D1 = first drive axle

D2 = second drive axle

$\mathrm{T} 1$ = first trailer axle

$\mathrm{T} 2$ = second trailer axle 
Date: 2 23-Jan-08 Strain Data File: $\underline{\text { 23Jan084.xIsx }}$ WIM VEN: $\quad 930$

HMA over Aggregate Base

\begin{tabular}{|c|c|c|c|c|c|c|c|c|c|c|c|c|c|}
\hline \multirow[b]{2}{*}{ Axle } & \multirow{2}{*}{$\begin{array}{c}\text { Axle Weight, } \\
\text { kips }\end{array}$} & \multicolumn{12}{|c|}{ Strain, microstrain } \\
\hline & & AB01 & $\mathrm{ABO2}$ & ABO3 & AB04 & AB05 & AB06 & AB07 & AB08 & AB09 & $\mathrm{AB} 10$ & AB11 & AB12 \\
\hline$S$ & 12.6 & 11.4 & 17.3 & 20.0 & 4.7 & 5.9 & 6.4 & 3.9 & 7.4 & 4.6 & 12.2 & 19.9 & 15.7 \\
\hline D1 & 25.0 & 19.7 & 29.2 & 25.6 & 4.0 & 17.8 & 11.3 & 3.1 & 19.2 & 8.5 & 20.7 & 32.2 & 22.4 \\
\hline $\mathrm{D} 2$ & 23.2 & 20.9 & 31.2 & 26.8 & 3.2 & 17.8 & 11.3 & 2.9 & 18.5 & 8.6 & 21.1 & 31.7 & 21.5 \\
\hline T1 & 22.9 & 16.1 & 25.6 & 22.5 & 3.7 & 17.8 & 10.3 & 2.5 & 18.7 & 7.0 & 18.3 & 29.7 & 20.3 \\
\hline $\mathrm{T} 2$ & 23.9 & 20.5 & 31.1 & 25.7 & 4.0 & 18.6 & 10.8 & 3.4 & 19.6 & 8.3 & 21.1 & 32.0 & 21.3 \\
\hline
\end{tabular}

HMA over Rubblized PCC Base

\begin{tabular}{|c|c|c|c|c|c|c|c|c|c|c|c|c|c|}
\hline \multirow[b]{2}{*}{ Axle } & \multirow{2}{*}{$\begin{array}{c}\text { Axle Weight, } \\
\text { kips }\end{array}$} & \multicolumn{12}{|c|}{ Strain, microstrain } \\
\hline & & RBO1 & RBO2 & RBO3 & RB04 & RB05 & RB06 & RB07 & RBo8 & RBO9 & RB10 & RB11 & RB12 \\
\hline$S$ & 12.6 & * & 9.8 & 7.8 & 3.2 & 3.9 & 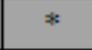 & 3.3 & 3.2 & * & $* *$ & * & 6.9 \\
\hline D1 & 25.0 & * & 14.6 & 9.2 & 3.8 & 9.7 & $*$ & 4.8 & 9.0 & $*$ & 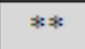 & $*$ & 9.4 \\
\hline $\mathrm{D} 2$ & & * & 16.0 & 10.4 & 4.0 & 10.2 & $*$ & 4.5 & 8.9 & * & $* *$ & $*$ & 8.4 \\
\hline $\mathrm{T} 1$ & 22.9 & * & 13.2 & 8.2 & 2.9 & 6.8 & * & 4.2 & 7.6 & * & $* *$ & * & 8.2 \\
\hline T2 & 23.9 & * & 16.3 & 10.1 & 4.2 & 10.4 & * & 4.9 & 9.4 & * & $* *$ & * & 8.4 \\
\hline
\end{tabular}

Shading:

Longitudinal gages

Tranverse gages

- Unable to determine due to poor gage response

* Gage was not responding
Axles:

$S=$ steering axle

D1 = first drive axle

D2 = second drive axle

$\mathrm{T} 1$ = first trailer axle

$\mathrm{T} 2$ = second trailer axle 


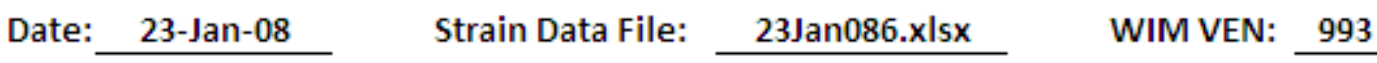

HMA over Aggregate Base

\begin{tabular}{|c|c|c|c|c|c|c|c|c|c|c|c|c|c|}
\hline \multirow[b]{2}{*}{ Axle } & \multirow{2}{*}{$\begin{array}{c}\text { Axle Weight, } \\
\text { kips }\end{array}$} & \multicolumn{12}{|c|}{ Strain, microstrain } \\
\hline & & AB01 & AB02 & АВ03 & $\mathrm{ABO4}$ & AB05 & AB06 & AB07 & AB08 & ABO9 & AB10 & AB11 & AB12 \\
\hline S & & 11.4 & 18.8 & 17.3 & 4.0 & 8.7 & 3.3 & 3.7 & 9.7 & 2.1 & 12.0 & 21.2 & 13.4 \\
\hline D1 & & 14.9 & 22.9 & 17.4 & 1.8 & 13.9 & 4.9 & 1.1 & 14.8 & 3.7 & 15.3 & 23.5 & 14.3 \\
\hline $\mathrm{D} 2$ & 15.0 & 15.6 & 22.2 & 17.5 & 1.7 & 13.4 & 5.0 & 1.5 & 13.1 & 3.7 & 15.8 & 22.4 & 14.3 \\
\hline T1 & & 8.3 & 12.6 & 11.7 & 6.4 & 7.3 & 3.8 & 3.2 & 7.6 & 2.8 & 0.5 & 3.3 & 9.6 \\
\hline $\mathrm{T} 2$ & 13.9 & 8.8 & 12.6 & 12.3 & 2.1 & 7.2 & 3.9 & 2.1 & 7.6 & 2.9 & 11.2 & 13.7 & 10.2 \\
\hline
\end{tabular}

HMA over Rubblized PCC Base

\begin{tabular}{|c|c|c|c|c|c|c|c|c|c|c|c|c|c|}
\hline \multirow[b]{2}{*}{ Axle } & \multirow{2}{*}{\begin{tabular}{|c|}
$\begin{array}{c}\text { Axle Weight, } \\
\text { kips }\end{array}$ \\
\end{tabular}} & \multicolumn{12}{|c|}{ Strain, microstrain } \\
\hline & & RB01 & RBO2 & RBO3 & RBO4 & RB05 & RB06 & RB07 & RB08 & RBO9 & RB10 & RB11 & RB12 \\
\hline $\mathrm{S}$ & 11.8 & * & 8.9 & 9.7 & 3.6 & 2.5 & $*$ & 3.3 & 1.8 & * & $* *$ & * & 8.8 \\
\hline D1 & 14.7 & * & 11.2 & 9.5 & 3.4 & 6.7 & * & 3.8 & 6.0 & * & $* *$ & * & 8.7 \\
\hline $\mathrm{D} 2$ & 15.0 & * & 10.5 & 9.0 & 3.8 & 6.5 & * & 3.6 & 5.0 & * & $* *$ & $*$ & 7.4 \\
\hline T1 & 13.7 & * & 6.0 & 6.1 & 2.8 & 2.5 & * & 2.7 & 1.8 & * & $* *$ & $*$ & 6.3 \\
\hline $\mathrm{T} 2$ & 13.9 & * & 5.2 & 5.2 & 3.1 & 2.4 & $*$ & 2.7 & 1.9 & * & $* *$ & $*$ & 6.1 \\
\hline
\end{tabular}

Shading:

Longitudinal gages

Tranverse gages

- Unable to determine due to poor gage response

* Gage was not responding
Axles:

$$
S=\text { steering axle }
$$

D1 = first drive axle

D2 = second drive axle

$\mathrm{T} 1$ = first trailer axle

$\mathrm{T} 2$ = second trailer axle 


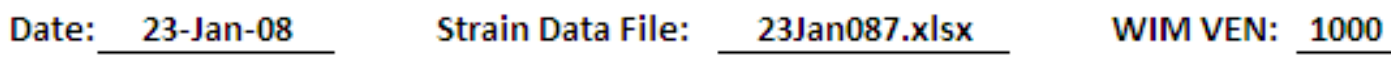

HMA over Aggregate Base

\begin{tabular}{|c|c|c|c|c|c|c|c|c|c|c|c|c|c|}
\hline \multirow[b]{2}{*}{ Axle } & \multirow{2}{*}{$\begin{array}{c}\text { Axle Weight, } \\
\text { kips }\end{array}$} & \multicolumn{12}{|c|}{ Strain, microstrain } \\
\hline & & AB01 & АBO2 & АВ03 & $\mathrm{ABO4}$ & AB05 & AB06 & ABO7 & AB08 & AB09 & AB10 & AB11 & AB12 \\
\hline S & 1. & 12.3 & 15.8 & 27.7 & 5.0 & $*$ & 15.7 & 4.3 & $*$ & 10.5 & 12.9 & 18.3 & 23.7 \\
\hline D1 & & 14.8 & 19.2 & 28.0 & 2.6 & * & 12.2 & 2. & * & 11.1 & 14.8 & 21.1 & 21.2 \\
\hline $\mathrm{D} 2$ & 12.1 & 15.3 & 20.6 & 27.3 & 4.0 & * & 16.7 & 3.2 & 3 & 12.2 & 15.8 & 22.4 & 23.5 \\
\hline $\mathrm{T} 1$ & - & 15.1 & 20.3 & 31.5 & 5.1 & 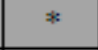 & 21.3 & 3.7 & 3 & 15.8 & 16.0 & 23.4 & 28.2 \\
\hline $\mathrm{T} 2$ & 12.1 & 16.5 & 22.2 & 32.4 & 4.9 & * & 22.2 & 4.7 & $*$ & 15.3 & 17.5 & 25.2 & 29.3 \\
\hline
\end{tabular}

HMA over Rubblized PCC Base

\begin{tabular}{|c|c|c|c|c|c|c|c|c|c|c|c|c|c|}
\hline \multirow[b]{2}{*}{ Axle } & \multirow{2}{*}{$\begin{array}{c}\text { Axle Weight, } \\
\text { kips }\end{array}$} & \multicolumn{12}{|c|}{ Strain, microstrain } \\
\hline & & RBO1 & RBO2 & RBO3 & RBO4 & RB05 & RBO6 & RB07 & RB08 & RBO9 & RB10 & RB11 & RB12 \\
\hline S & 12.6 & * & 9.4 & 10.9 & 3.3 & 1.9 & * & 3.3 & 1.2 & * & $* *$ & * & 9.8 \\
\hline D1 & 11.5 & * & 11.5 & 9.7 & 3.0 & 6.2 & * & 3.5 & 5.6 & * & $* *$ & * & 9.2 \\
\hline D2 & 12.1 & * & 12.3 & 10.9 & 3.5 & 6.3 & * & 3.5 & 5.0 & * & $* *$ & * & 9.1 \\
\hline T1 & 11.9 & * & 11.2 & 10.7 & 4.0 & 4.9 & * & 4.2 & 3.8 & * & $* *$ & * & 12.2 \\
\hline $\mathrm{T} 2$ & 12.1 & $*$ & 13.4 & 13.5 & 4.4 & 5.1 & * & 4.4 & 4.6 & * & $* *$ & * & 11.3 \\
\hline
\end{tabular}

Shading:

Longitudinal gages

Tranverse gages

- Unable to determine due to poor gage response

* Gage was not responding
Axles:

$$
S=\text { steering axle }
$$

D1 = first drive axle

D2 = second drive axle

$\mathrm{T} 1$ = first trailer axle

$\mathrm{T} 2$ = second trailer axle 
Date: 23-Jan-08

Strain Data File: $\quad$ 23Jan092.xlsx

WIM VEN: 1019

HMA over Aggregate Base

\begin{tabular}{|c|c|c|c|c|c|c|c|c|c|c|c|c|c|}
\hline \multirow[b]{2}{*}{ Axle } & \multirow{2}{*}{$\begin{array}{c}\text { Axle Weight, } \\
\text { kips }\end{array}$} & \multicolumn{12}{|c|}{ Strain, microstrain } \\
\hline & & AB01 & $\mathrm{AB} 02$ & AB03 & AB04 & AB05 & AB06 & AB07 & AB08 & AB09 & $\mathrm{AB} 10$ & AB11 & AB12 \\
\hline $\mathrm{S}$ & 12.6 & 12.6 & 14.8 & 31.4 & 5.4 & * & 23.5 & 4.5 & . & 17.6 & 13.4 & 17.0 & 27.5 \\
\hline D1 & 21.3 & 17.7 & 21.2 & 35.5 & 4.3 & * & 24.2 & 2.6 & $*$ & 17.3 & 18.8 & 24.0 & 30.9 \\
\hline $\mathrm{D} 2$ & 0.7 & 18.0 & 21.1 & 35.5 & 3.5 & * & 24.2 & 2.4 & * & 17.9 & 18.5 & 22.6 & 31.0 \\
\hline T1 & 21.6 & 19.7 & 22.0 & 43.4 & 6.0 & * & 24.1 & 4.4 & - & 17.7 & 20.1 & 24.8 & 35.7 \\
\hline $\mathrm{T} 2$ & 20.0 & 19.3 & 22.8 & 44.6 & 11.2 & * & 25.4 & 4.8 & $*$ & 18.3 & 20.6 & 26.3 & \begin{tabular}{|l|}
37.4 \\
\end{tabular} \\
\hline
\end{tabular}

HMA over Rubblized PCC Base

\begin{tabular}{|c|c|c|c|c|c|c|c|c|c|c|c|c|c|}
\hline \multirow[b]{2}{*}{ Axle } & \multirow{2}{*}{$\begin{array}{c}\text { Axle Weight, } \\
\text { kips }\end{array}$} & \multicolumn{12}{|c|}{ Strain, microstrain } \\
\hline & & RB01 & RBO2 & RBO3 & RB04 & RB05 & RB06 & RB07 & RB08 & RBO9 & RB10 & RB11 & RB12 \\
\hline$S$ & 12.6 & * & 6.7 & 14.3 & 3.9 & * & * & 2.8 & * & * & $* *$ & * & 14.6 \\
\hline D1 & 21.3 & * & 9.9 & 15.7 & 4.1 & * & * & 3.1 & * & * & *** & * & 15.7 \\
\hline $\mathrm{D} 2$ & 20.7 & * & 9.5 & 16.4 & 4.5 & $*$ & $*$ & 2.8 & * & * & $* *$ & * & 14.5 \\
\hline T1 & 21.6 & * & 10.4 & 19.0 & 5.1 & $*$ & $*$ & 3.4 & * & $*$ & $* *$ & $*$ & 19.1 \\
\hline $\mathrm{T} 2$ & 20.0 & * & 11.0 & 20.4 & 5.2 & * & * & 3.5 & $*$ & $*$ & $* *$ & $*$ & 20.2 \\
\hline
\end{tabular}

Shading:

Longitudinal gages

Tranverse gages

- Unable to determine due to poor gage response

*Gage was not responding
Axles:

$\mathrm{S}=$ steering axle

D1 = first drive axle

D2 = second drive axle

T1 = first trailer axle

$\mathrm{T} 2$ = second trailer axle 
Date: 23-Jan-08 Strain Data File: 23 23an110.xIsx $\quad$ WIM VEN: $\underline{1082}$

HMA over Aggregate Base

\begin{tabular}{|c|c|c|c|c|c|c|c|c|c|c|c|c|c|}
\hline \multirow[b]{2}{*}{ Axle } & \multirow{2}{*}{$\begin{array}{c}\text { Axle Weight, } \\
\text { kips }\end{array}$} & \multicolumn{12}{|c|}{ Strain, microstrain } \\
\hline & & AB01 & AB02 & ABO3 & ABO4 & AB05 & AB06 & AB07 & AB08 & AB09 & AB10 & AB11 & AB12 \\
\hline $\mathrm{S}$ & 12.7 & 12.4 & 17.4 & 23.6 & 6.6 & 4.6 & 10.4 & 4.3 & 5.2 & 6.6 & 12.9 & 19.7 & 19.3 \\
\hline D1 & 20.7 & 17.4 & 23.7 & 27.7 & 5.3 & 11.1 & 14.7 & 3.8 & 11.5 & 11.0 & 18.5 & 26.3 & 24.1 \\
\hline $\mathrm{D} 2$ & 21.8 & 19.3 & 26.6 & 29.8 & 4.8 & 11.4 & 14.3 & 3.9 & 11.6 & 11.0 & 20.0 & 28.1 & 24.5 \\
\hline $\mathrm{T} 1$ & 26.5 & 17.2 & 22.7 & 26.3 & 4.7 & 11.3 & 14.5 & 3.2 & 11.5 & 11.0 & 18.1 & 25.4 & 22.8 \\
\hline $\mathrm{T} 2$ & 23.7 & 18.3 & 24.9 & 27.8 & 5.3 & 10.8 & 14.8 & 3.8 & 11.1 & 11.2 & 19.4 & 27.0 & 24.1 \\
\hline
\end{tabular}

HMA over Rubblized PCC Base

\begin{tabular}{|c|c|c|c|c|c|c|c|c|c|c|c|c|c|}
\hline \multirow[b]{2}{*}{ Axle } & \multirow{2}{*}{$\begin{array}{c}\text { Axle Weight, } \\
\text { kips }\end{array}$} & \multicolumn{12}{|c|}{ Strain, microstrain } \\
\hline & & RB01 & RBO2 & RBO3 & RBO4 & RB05 & RB06 & RBO & RBOS & RBOS & RB10 & RB11 & RB12 \\
\hline$S$ & 12.7 & * & 8.2 & 12.6 & 3.7 & 0.8 & * & 3.2 & 0.3 & $*$ & $* *$ & * & 12.0 \\
\hline D1 & 2 & * & 11.4 & 13.7 & 4.8 & 2.7 & * & 0 & 0 & * & $* *$ & * & 14.3 \\
\hline $\mathrm{D} 2$ & 2 & * & 13.2 & 15.4 & 5.3 & 2.8 & * & 4.2 & 4 & * & $* *$ & $*$ & 13.9 \\
\hline $\mathrm{T} 1$ & 26.5 & * & 12.1 & 13.2 & 4.9 & 2.3 & * & 4.1 & 1.1 & * & $* *$ & $*$ & 13.8 \\
\hline $\mathrm{T} 2$ & 23.7 & * & 13.4 & 15.3 & 5.3 & 2.7 & * & 4.1 & 1.4 & * & $* *$ & $*$ & 13.8 \\
\hline
\end{tabular}

Shading:

Longitudinal gages

Tranverse gages

- Unable to determine due to poor gage response

* Gage was not responding
Axles:

$$
S=\text { steering axle }
$$

D1 = first drive axle

D2 = second drive axle

$\mathrm{T} 1$ = first trailer axle

$\mathrm{T} 2$ = second trailer axle 


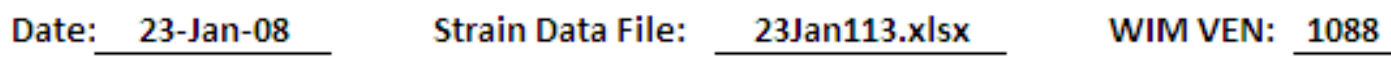

HMA over Aggregate Base

\begin{tabular}{|c|c|c|c|c|c|c|c|c|c|c|c|c|c|}
\hline \multirow[b]{2}{*}{ Axle } & \multirow{2}{*}{$\begin{array}{c}\text { Axle Weight, } \\
\text { kips }\end{array}$} & \multicolumn{12}{|c|}{ Strain, microstrain } \\
\hline & & AB01 & AB02 & AB03 & AB04 & AB05 & AB06 & $\mathrm{AB} 07$ & AB08 & ABO9 & AB10 & AB11 & AB12 \\
\hline$S$ & 0 & 12.1 & 19.6 & 18.3 & 3.7 & 7.2 & 2.9 & 3.2 & 6 & 1.7 & 12.4 & 21.5 & 14.2 \\
\hline D1 & & 14.0 & 21.0 & 17.6 & 4.5 & 11.7 & 3.8 & 1.6 & 12.1 & 2.8 & 14.5 & 21.7 & 13.1 \\
\hline $\mathrm{D} 2$ & & 14.6 & 21.5 & 17.8 & 1.8 & 11.5 & 4.5 & 1.6 & 12.0 & 3.3 & 14.9 & 21.6 & 14.0 \\
\hline $\mathrm{T} 1$ & 22.4 & 13.1 & 20.1 & 19.5 & 4.3 & 11.1 & 8.5 & 2.8 & 12.2 & 6.0 & 14.6 & 23.2 & 17.8 \\
\hline T2 & 22.9 & 15.2 & 22.8 & 22.6 & 4.4 & 11.2 & 9.0 & 3.9 & 12.1 & 7.0 & 16.4 & 25.3 & 20.3 \\
\hline
\end{tabular}

HMA over Rubblized PCC Base

\begin{tabular}{|c|c|c|c|c|c|c|c|c|c|c|c|c|c|}
\hline \multirow[b]{2}{*}{ Axle } & \multirow{2}{*}{$\begin{array}{c}\text { Axle Weight, } \\
\text { kips }\end{array}$} & \multicolumn{12}{|c|}{ Strain, microstrain } \\
\hline & & RBO1 & RBO2 & RBO3 & RBO4 & RB05 & RBO6 & RB07 & RB08 & RBO9 & RB10 & RB11 & RB12 \\
\hline $\mathrm{S}$ & 14.0 & * & 10.7 & 8.2 & 2.8 & 5.2 & * & 3.2 & 4.6 & * & $* *$ & * & 7.0 \\
\hline D1 & 16.5 & * & 9.0 & 7.2 & 2.3 & 7.7 & * & 3.3 & 6.9 & * & $* *$ & * & 6.1 \\
\hline $\mathrm{D} 2$ & 18.1 & * & 10.2 & 6.6 & 2.6 & 6.9 & * & 3.1 & 6.0 & * & $* *$ & * & 6.5 \\
\hline T1 & 22.4 & * & 11.5 & 9.7 & 3.2 & 6.8 & * & 3.9 & 6.1 & * & $* *$ & * & 10.9 \\
\hline $\mathrm{T} 2$ & 22.9 & * & 12.8 & 11.9 & 3.8 & 6.6 & * & 4.1 & 5.7 & * & $* *$ & * & 11.2 \\
\hline
\end{tabular}

Shading:

Longitudinal gages

Tranverse gages

- Unable to determine due to poor gage response

* Gage was not responding
Axles:

$$
S=\text { steering axle }
$$

D1 = first drive axle

D2 = second drive axle

T1 = first trailer axle

T2 = second trailer axle 


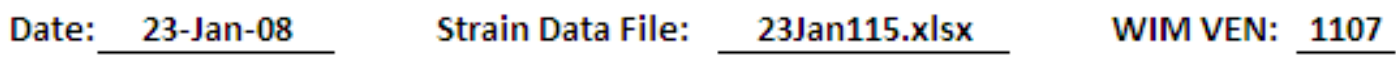

HMA over Aggregate Base

\begin{tabular}{|c|c|c|c|c|c|c|c|c|c|c|c|c|c|}
\hline \multirow[b]{2}{*}{ Axle } & \multirow{2}{*}{$\begin{array}{c}\text { Axle Weight, } \\
\text { kips }\end{array}$} & \multicolumn{12}{|c|}{ Strain, microstrain } \\
\hline & & AB01 & ABO2 & ABO3 & ABO4 & AB05 & AB06 & AB07 & AB08 & AB09 & AB10 & AB11 & AB12 \\
\hline $\mathrm{S}$ & 11.8 & 12.0 & 17.2 & 20.4 & 6.0 & 4.9 & 7.5 & 4.2 & $*$ & 5.4 & 12.2 & 18.9 & 17.3 \\
\hline D1 & 20.2 & 12.3 & 15.4 & 19.1 & 2.2 & 6.1 & 4.9 & 1.4 & * & 2.8 & 10.7 & 12.3 & 10.1 \\
\hline $\mathrm{D} 2$ & 23.7 & 8.9 & 12.0 & 12.6 & 1.9 & 6.1 & 5.1 & 1.5 & * & 3.8 & 9.5 & 12.6 & 9.7 \\
\hline T1 & 26.1 & 5.4 & 7.0 & 8.7 & 4.3 & 2.1 & 3.4 & 1.3 & * & 2.3 & 5.6 & 8.0 & 7.2 \\
\hline $\mathrm{T} 2$ & 25.5 & 6.0 & 8.3 & 9.6 & 1.5 & 2.4 & 3.3 & 1.5 & * & 1.9 & 5.7 & 7.9 & 6.5 \\
\hline
\end{tabular}

HMA over Rubblized PCC Base

\begin{tabular}{|c|c|c|c|c|c|c|c|c|c|c|c|c|c|}
\hline \multirow[b]{2}{*}{ Axle } & \multirow{2}{*}{$\begin{array}{c}\text { Axle Weight, } \\
\text { kips }\end{array}$} & \multicolumn{12}{|c|}{ Strain, microstrain } \\
\hline & & RB01 & RB02 & RB03 & RBO4 & RB05 & RB06 & RB07 & RB08 & RBO9 & RB10 & RB11 & RB12 \\
\hline $\mathrm{S}$ & 11.8 & * & 6.4 & 13.1 & 3.6 & * & $*$ & 2.6 & * & * & $* *$ & $*$ & 13.5 \\
\hline D1 & 20.2 & * & 4.7 & 6.7 & 3.5 & * & * & 1.6 & * & * & $* *$ & * & 6.3 \\
\hline $\mathrm{D} 2$ & 23.7 & * & 4.5 & 6.9 & 2.2 & * & * & 1.5 & * & * & $* *$ & * & 6.1 \\
\hline T1 & 26.1 & * & 3.0 & 5.0 & 1.3 & * & * & 0.9 & * & $*$ & $* *$ & $*$ & 3.9 \\
\hline $\mathrm{T} 2$ & 25.5 & * & 3.3 & 5.3 & 1.3 & $*$ & $*$ & 0.8 & * & * & $* *$ & * & 3.7 \\
\hline
\end{tabular}

Shading:

Longitudinal gages

Tranverse gages

- Unable to determine due to poor gage response

* Gage was not responding
Axles:

$\mathrm{S}=$ steering axle

D1 = first drive axle

D2 = second drive axle

$\mathrm{T} 1$ = first trailer axle

$\mathrm{T} 2$ = second trailer axle 


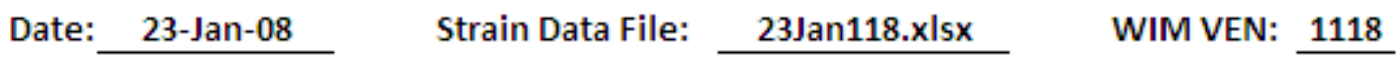

HMA over Aggregate Base

\begin{tabular}{|c|c|c|c|c|c|c|c|c|c|c|c|c|c|}
\hline \multirow[b]{2}{*}{ Axle } & \multirow{2}{*}{$\begin{array}{c}\text { Axle Weight, } \\
\text { kips }\end{array}$} & \multicolumn{12}{|c|}{ Strain, microstrain } \\
\hline & & AB01 & AB02 & АВ03 & $\mathrm{ABO4}$ & AB05 & AB06 & ABO7 & AB08 & ABO9 & AB10 & AB11 & AB12 \\
\hline S & 13.7 & 11.6 & 15.2 & 26.8 & 5.3 & $*$ & 12.7 & 4.2 & * & 8.4 & 13.0 & 17.5 & 22.7 \\
\hline D1 & 10.0 & 11.9 & 13.3 & 14.1 & 2.0 & 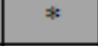 & 7.6 & 1.6 & . & 4.5 & 13.7 & 17.7 & 20.4 \\
\hline $\mathrm{D} 2$ & 10.7 & 8.6 & 10.1 & 15.1 & 1.9 & 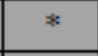 & 6.6 & 1.9 & * & 4.4 & 9.0 & 10.5 & 12.5 \\
\hline $\mathrm{T} 1$ & & 7.2 & 9.0 & 15.6 & 2.7 & $*$ & 8.2 & 1.6 & * & 5.2 & 7.8 & 10.0 & 13.3 \\
\hline $\mathrm{T} 2$ & 6 & 7.4 & 8.6 & 15.4 & 1.6 & $*$ & 6.9 & 1.2 & $*$ & 5.0 & 7.1 & 7.9 & 10.8 \\
\hline
\end{tabular}

HMA over Rubblized PCC Base

\begin{tabular}{|c|c|c|c|c|c|c|c|c|c|c|c|c|c|}
\hline \multirow[b]{2}{*}{ Axle } & \multirow{2}{*}{$\begin{array}{c}\text { Axle Weight, } \\
\text { kips }\end{array}$} & \multicolumn{12}{|c|}{ Strain, microstrain } \\
\hline & & RB01 & RB02 & RBO3 & RBO4 & RB05 & RB06 & RB07 & RB08 & RBO9 & RB10 & RB11 & RB12 \\
\hline $\mathrm{S}$ & 13.7 & * & 8.0 & 13.5 & 3.3 & 1.1 & $*$ & 3.0 & * & * & $* *$ & * & 13.2 \\
\hline D1 & 10.0 & * & 4.9 & 6.6 & 1.7 & 0.9 & * & 1.7 & * & * & $* *$ & * & 6.7 \\
\hline $\mathrm{D} 2$ & 10.7 & * & 4.6 & 7.1 & 2.1 & 1.1 & * & 1.8 & * & * & $* *$ & $*$ & 6.3 \\
\hline T1 & 9.7 & * & 4.2 & 6.3 & 1.5 & 0.6 & * & 1.6 & * & * & $* *$ & $*$ & 6.3 \\
\hline $\mathrm{T} 2$ & 8.6 & * & 3.6 & 6.4 & 1.8 & 0.8 & $*$ & 1.5 & * & * & $* *$ & $*$ & 5.4 \\
\hline
\end{tabular}

Shading:

Longitudinal gages

Tranverse gages

- Unable to determine due to poor gage response

* Gage was not responding
Axles:

$S=$ steering axle

D1 = first drive axle

D2 = second drive axle

$\mathrm{T} 1$ = first trailer axle

$\mathrm{T} 2$ = second trailer axle 


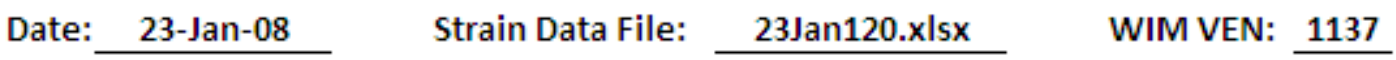

HMA over Aggregate Base

\begin{tabular}{|c|c|c|c|c|c|c|c|c|c|c|c|c|c|}
\hline \multirow[b]{2}{*}{ Axle } & \multirow{2}{*}{$\begin{array}{c}\text { Axle Weight, } \\
\text { kips }\end{array}$} & \multicolumn{12}{|c|}{ Strain, microstrain } \\
\hline & & AB01 & AB02 & ABO3 & ABO4 & AB05 & AB06 & AB07 & AB08 & AB09 & AB10 & AB11 & AB12 \\
\hline $\mathrm{S}$ & 13.9 & 12.3 & 18.8 & 19.8 & 4.4 & 6.5 & 6.1 & 3.8 & 8.1 & 4.2 & 12.9 & 21.3 & 16.1 \\
\hline D1 & 14.7 & 14.0 & 19.4 & 20.7 & 2.7 & 9.2 & 5.8 & 1.5 & 9.9 & 4.7 & 12.8 & 18.1 & 12.7 \\
\hline $\mathrm{D} 2$ & 14.7 & 12.2 & 17.2 & 15.5 & 1.9 & 9.0 & 6.1 & 1.5 & 9.6 & 4.7 & 12.3 & 16.8 & 12.1 \\
\hline T1 & 18.7 & 10.1 & 14.6 & 18.9 & 3.3 & 7.5 & 11.3 & 2.7 & 8.0 & 8.3 & 11.7 & 17.0 & 16.9 \\
\hline $\mathrm{T} 2$ & 21.8 & 12.8 & 18.6 & 22.2 & 4.1 & 8.5 & 11.8 & 4.4 & 9.5 & 8.9 & 13.9 & 20.9 & 18.7 \\
\hline
\end{tabular}

HMA over Rubblized PCC Base

\begin{tabular}{|c|c|c|c|c|c|c|c|c|c|c|c|c|c|}
\hline \multirow[b]{2}{*}{ Axle } & \multirow{2}{*}{$\begin{array}{c}\text { Axle Weight, } \\
\text { kips }\end{array}$} & \multicolumn{12}{|c|}{ Strain, microstrain } \\
\hline & & RB01 & RB02 & RB03 & RBO4 & RB05 & RB06 & RB07 & RB08 & RB09 & RB10 & RB11 & RB12 \\
\hline $\mathrm{S}$ & 13.9 & * & 9.4 & 10.0 & 3.5 & 2.3 & $*$ & 3.4 & 1.5 & * & $* *$ & * & 9.1 \\
\hline D1 & 14.7 & * & 8.0 & 6.6 & 2.7 & 4.2 & * & 2.8 & 3.5 & * & $* *$ & * & 6.4 \\
\hline $\mathrm{D} 2$ & 14.7 & * & 7.7 & 6.8 & 3.0 & 4.1 & * & 2.8 & 3.5 & * & $* *$ & * & 5.8 \\
\hline T1 & 18.7 & * & 7.3 & 9.3 & 3.2 & 2.3 & * & 3.1 & 1.5 & $*$ & $* *$ & $*$ & 9.5 \\
\hline $\mathrm{T} 2$ & 21.8 & * & 9.5 & 11.5 & 3.8 & 2.3 & $*$ & 3.8 & 1.4 & * & $* *$ & * & 10.5 \\
\hline
\end{tabular}

Shading:

Longitudinal gages

Tranverse gages

- Unable to determine due to poor gage response

* Gage was not responding
Axles:

$\mathrm{S}=$ steering axle

D1 = first drive axle

D2 = second drive axle

$\mathrm{T} 1$ = first trailer axle

$\mathrm{T} 2$ = second trailer axle 




\section{AOTREC \\ OREGON TRANSPORTATION RESEARCH \\ AND EDUCATION CONSORTIUM}

\section{P.O. Box 751}

Portland, OR 97207

OTREC is dedicated to stimulating and conducting collaborative multi-disciplinary research on multi-modal surface transportation issues, educating a diverse array of current practitioners and future leaders in the transportation field, and encouraging implementation of relevant research results. 